\title{
HIGH INTEREST, LOW ADOPTION. A MIXED-METHOD INVESTIGATION INTO THE FACTORS INFLUENCING ORGANIZATIONAL ADOPTION OF BLOCKCHAIN TECHNOLOGY
}

\author{
by Ryan William Kennedy \\ Bachelor of Commerce, Ryerson University, 2017
}

\author{
A thesis \\ presented to Ryerson University \\ in partial fulfillment of the \\ requirements for the degree of \\ Master of Science in Management (MScM) \\ in the program of \\ Master of Science in Management
}

Toronto, Ontario, Canada, 2020

(C) Ryan William Kennedy, 2020 


\section{AUTHOR'S DECLARATION FOR ELECTRONIC SUBMISSION OF A THESIS}

I hereby declare that I am the sole author of this thesis. This is a true copy of the thesis, including any required final revisions, as accepted by my examiners.

I authorize Ryerson University to lend this thesis to other institutions or individuals for the purpose of scholarly research.

I further authorize Ryerson University to reproduce this thesis by photocopying or by other means, in total or in part, at the request of other institutions or individuals for the purpose of scholarly research.

I understand that my thesis may be made electronically available to the public. 
HIGH INTEREST, LOW ADOPTION. A MIXED-METHOD INVESTIGATION INTO THE FACTORS INFLUENCING ORGANIZATIONAL ADOPTION OF BLOCKCHAIN TECHNOLOGY

Ryan William Kennedy

Master of Science in Management (MScM), 2020

Master of Science in Management, Ryerson University

\begin{abstract}
Statistics show high levels of interest in blockchain technology, however, considerable adoption has not occurred. This research examines why interest is high, yet levels of adoption are low, by identifying the factors influencing blockchain's adoption and systematizing them into a theoretical framework. A mixed methodology is used to address the adoption factors. First, a qualitative approach is used to discover the factors from primary data collected from 25 interviews with 23 different organizations. Second, a survey is employed to empirically test the factors with 146 employees from 71 organizations. A total of 18 factors are discovered and seven are tested. The findings support and validate several factors influencing blockchain adoption and contribute a novel factor; perceived technological volatility. A new empirically validated scale is developed to measure organizational perceptions of a technology's volatility. Furthermore, this research is one of the first to employ a mixed methodology to address blockchain technology adoption.
\end{abstract}




\section{Acknowledgements}

I wish to acknowledge the love and support of my Mother, Sherry, and Father, Owen, my Grandmother, Ellen, and my Girlfriend, Mollia. They were always there for me when stress or anxiety would arise. Without their calming influence and sensible words this research would not have been possible. I want to specifically thank my Mother for the hours spent re-assuring and guiding me from the very first day to the last. No matter the time of day, I always knew I could count on her. I want to thank my Father for his wise advice and reassuring attitude. I want to thank my grandmother for all the phone calls on my walk home from the office and I want to thank my girlfriend for traveling late in the night to see me when I needed her. I am forever grateful for my family.

I am grateful for my supervisor Dr. Atefeh Mashatan, who inspired me to start this academic journey and offered her continued guidance and support throughout. Without Dr. Mashatan's persistent mentoring, this research would not have been successful. She has helped elevate my confidence and I have learned so much from her. I cannot express how thankful I am to have had a supervisor like Atty.

Finally, I would like to thank my defence committee, specifically Dr. Linying Dong, Dr. Ozgur Turetken, and Dr. Ayse Yuce for their valuable feedback. With their input the quality of the thesis has been enhanced. 


\section{Dedication}

This master's thesis is dedicated to Ellen and William Kennedy, my Grandmother and Grandfather, whose example and support showed me academia is the way to a successful life. Without both of you, I would not be where I am today. 
Table of Contents

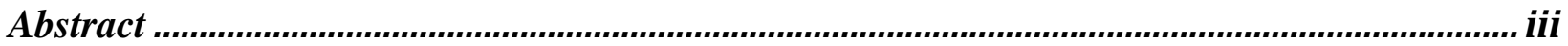

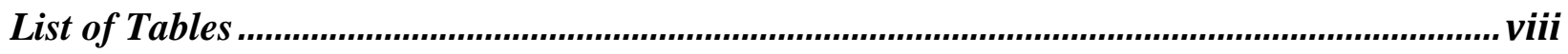

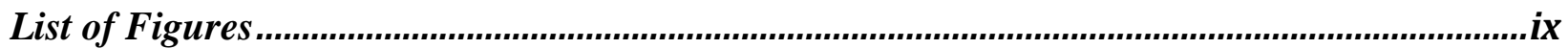

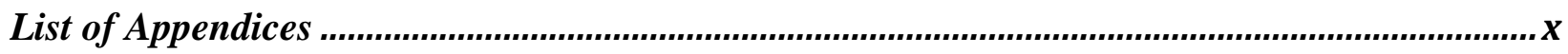

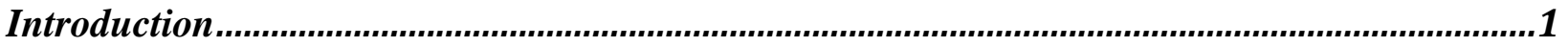

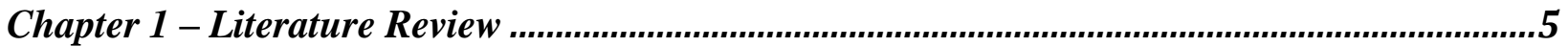

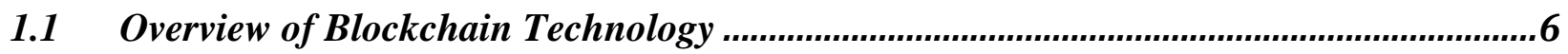

$1.2 \quad$ Antecedent Studies of Blockchain Adoption ....................................................................8

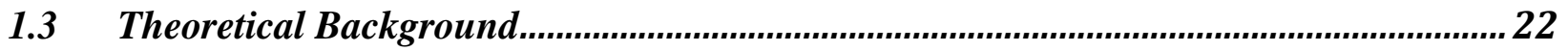

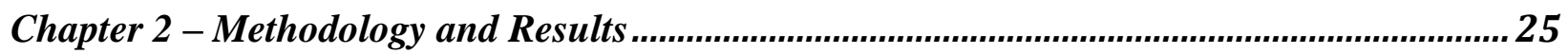

2.1 Study 1 - Qualitative Method - Exploratory Multiple-Case Study ................................. 28

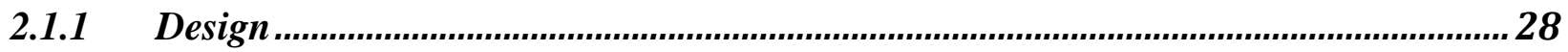

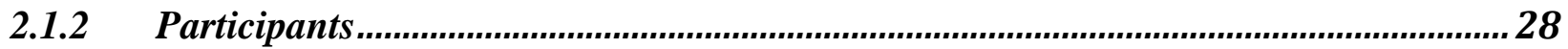

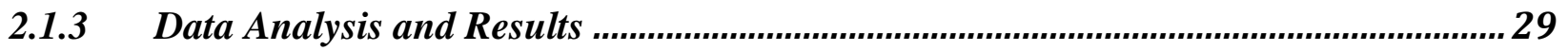

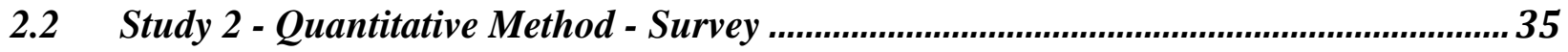

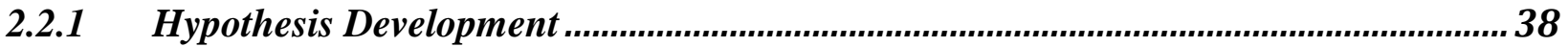

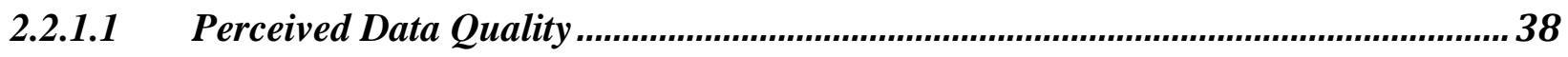

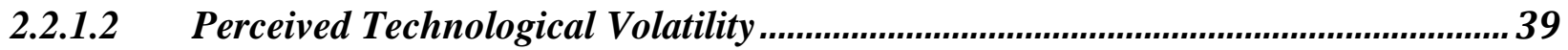

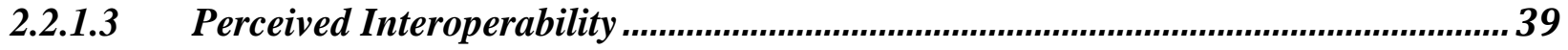

2.2.1.4 Perceived Lack of Technological Knowledge ......................................................... 40

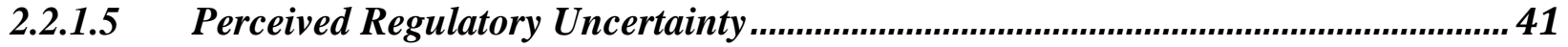

2.2.1.6 Perceived Standardization Uncertainty ............................................................... 42

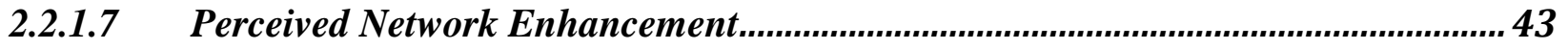

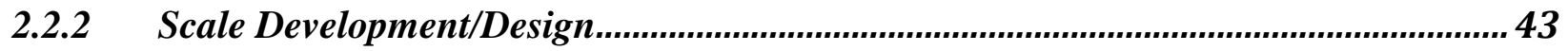

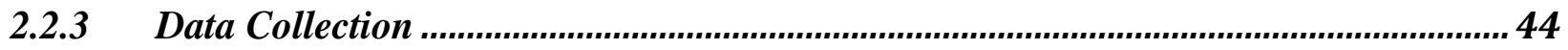

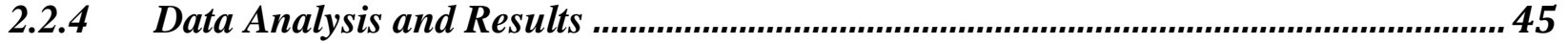

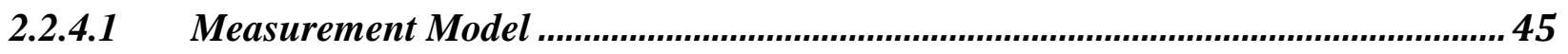

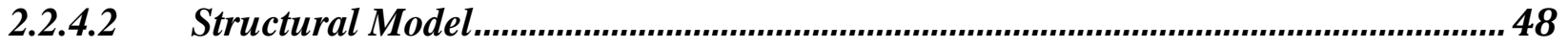

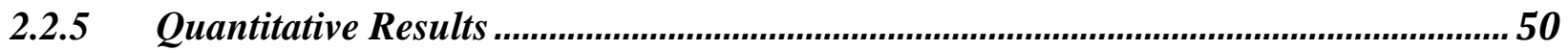




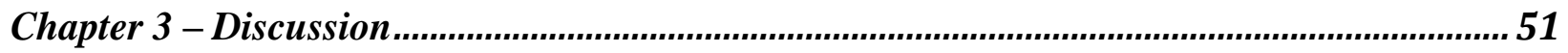

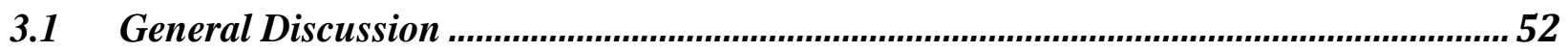

3.2 Managerial Insights for Blockchain Technology Development ...................................56

Chapter 4 - Theoretical and Practical Implications ................................................................. 70

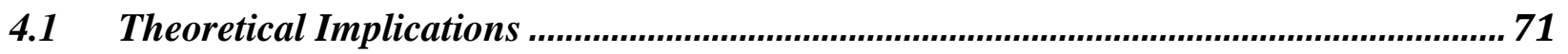

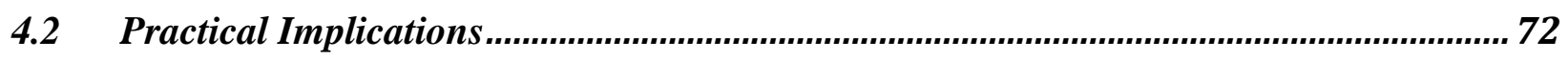

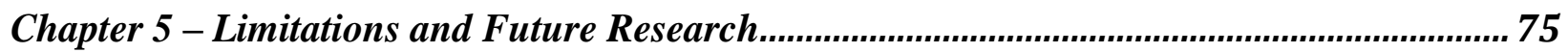

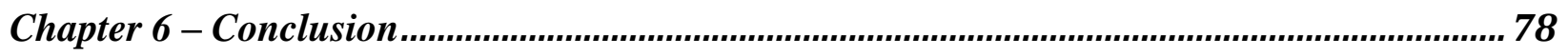

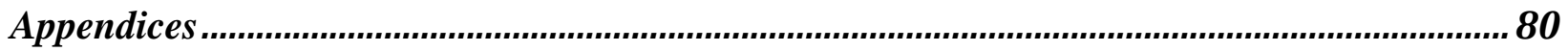

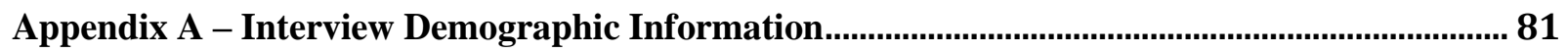

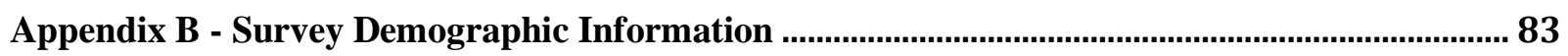

Appendix C - Organizational Blockchain Adoption Factors - Interview Results.......................... 84

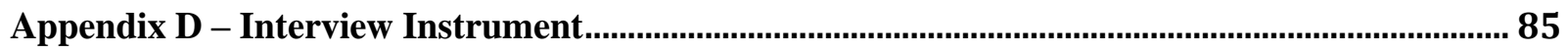

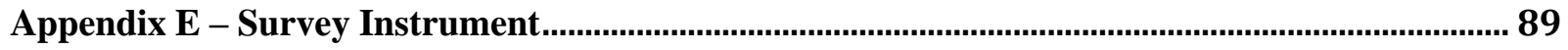

Appendix F- Innovation Within Networks: Patent Strategies for Blockchain Technology .......... 93

Copyright Permission (Journal of Business \& Industrial Marketing, Emerald Publishing).117

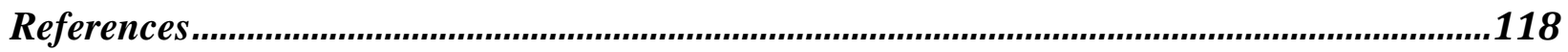




\section{List of Tables}

1. Table 1 - Evolution of Blockchain Definitions 6

2. Table 2-Antecedent Blockchain Adoption Studies 10

3. Table 3-Organizational - Level Blockchain Adoption Factors 30

4. Table 4-Measurement Model 46

5. Table 5-Heterotrait - Monotrait Ratio 47

6. Table 6-Hypothesis Results 48

7. Table 7 - Industries and Use Cases 56

8. Table 8 - Breakdown of Cost and Length Factors 59 


\section{List of Figures}

1. Figure 1-Mixed Methodology Overview 27

2. Figure 2-Preliminary Model 37

3. Figure 3 - PLS Structural Model with Path Coefficients 49

4. Figure 4 - Blockchain Technology Timeline 68 


\section{List of Appendices}

1. Appendix A - Interview Demographic Information 81

2. Appendix B - Survey Demographic Information 83

3. Appendix C-Organizational Blockchain Adoption Factors - Interview Results 84

4. Appendix D - Interview Instrument 85

5. Appendix E - Survey Instrument 89

6. Appendix F - Innovation Within Networks - Patent Strategies for Blockchain 93 Technology 


\section{Introduction}

Blockchain technology is a novel and disruptive innovation that has captured the attention of both industry and academia since its inception. The concept was first introduced in the seminal work by Satoshi Nakamoto titled; Bitcoin: A Peer-to-Peer Electronic Cash System (Nakamoto, 2008). Nakamoto (2008) describes a blockchain as a peer-to-peer network for direct transactions in a trust-less environment and explains how a blockchain is a solution to the double spend problem, made possible by using a distributed timestamp server that generates computational proofs of the network's transactions in chronological order. The original purpose of a blockchain was to conduct transactions using cryptocurrencies such as Bitcoin, however, individuals and organizations quickly realized the underlying technology had more potential. As a result, newer blockchains, such as Ethereum, were developed that have enhanced capabilities such as a Turing complete programming language which allows for enhanced functions such as automation (smart contracts) (Buterin, 2018). Overall, blockchains are the result of combining multiple technological components/concepts together to create something new.

Blockchain technology has a wide range of benefits for individuals, organizations and society. It allows for direct peer-to-peer transactions in a trust-less environment, near real-time transaction settlement and reconciliation, instant tracking and tracing of assets, data provenance, tamper evident data, irreversibility, distributivity, efficiency gains, cost reductions, automated contract enforcement, and a security model that is fault tolerant and resilient ( $\mathrm{Li}, \mathrm{Liu}$, Wang, Vatankhah Barenji, \& Huang, 2019; Lacity, 2018; Narayanan, Bonneau, Felten, Miller, \& Goldfeder, 2016). As organizations begin to adopt blockchain technology and reap the benefits, individuals and society will also benefit. For example, Walmart is using blockchain technology to provide provenance for their leafy green produce that will allow them to reduce E. coli outbreaks (Rossow, 2018). This is not only beneficial for Walmart in terms of cost savings, efficiency gains and/or brand image, it is also beneficial to individuals and society in terms of improved public health. This is just one use case implemented by a single organization, yet highlights the need for adoption. If ubiquitous adoption occurs, the benefits will scale and individuals, organizations, and society will all benefit tremendously.

As more functions are developed and the list of use cases expands, the number of benefits grow, as does interest in the technology itself. In 2016, the blockchain technology market was 
estimated to be worth 210.2 million USD and is predicted to be worth 2.31 billion USD by 2021 (Statista, 2016) and 7.59 billion USD by 2024 (Grand View Research, 2018). Other statistics project even larger values with estimates that by 2025 the business value added by blockchain technology will be 176 billion USD and by 2030 it will exceed 3.1 trillion USD (Granetto, Kandaswamy, Lovelock, \& Reynolds, 2017). The World Economic Forum has projected that $45 \%$ of organizations worldwide will have adopted blockchain technology by 2022 (Leopold, Ratcheva, \& Zahidi, 2018). In addition, a PricewaterhouseCoopers (PwC) survey of 600 executives geographically distributed around the world, shows $84 \%$ of organizations are involved, in one way or another, with blockchain technology (PwC, 2018). Combined, these statistics show that the market is projected to grow, and levels of interest are high. However, they do not tell the whole story. A deeper investigation of the $\mathrm{PwC}$ report shows that only $15 \%$ of the organizations involved in blockchain technology had gone to production with a solution (PwC, 2018). Furthermore, a more recent report from Statista shows that only $16.2 \%$ of organizations worldwide have adopted a blockchain solution in production (Statista, 2018). Lacity (2018) provides further support for the lack of adoption noting a recent survey of 200 blockchain projects has shown only $10 \%$ of respondents reported they had deployed a blockchain application and none of these deployments had been scaled. In most large organizations there are three sequential environments for technological projects; development, testing, and production. Development is where the technological solution is created, testing is where its functionality and usability is analyzed, and production is when the solution is fully adopted and implemented. It seems that there is great interest in blockchain, and the interest is growing, but there are factors holding back productionlevel adoption.

This dilemma merits an investigation. If the benefits of blockchain technology are to be realized, organizations must adopt, implement, and make use of the technology in production. The implementations must go beyond a proof-of-concept. The problem this research examines is the opaque nature of the reasons why there exist so much interest in blockchain technology yet such low levels of adoption. In other words, there is a lack of understating of the adoption factors, both drivers and barriers, which this research addresses. With a comprehensive understanding of the adoption factors, changes that could enhance the drivers and reduce the barriers, will be discovered and may be implemented. This could result in a faster rate of adoption and more ubiquitous diffusion of blockchain technology. To address this dilemma, this research aims to identify the 
factors influencing blockchain technology's adoption from primary data as opposed to re-testing an existing framework or collecting the factors from secondary data such as prior blockchain adoption studies and, to empirically test the factors to develop a theoretical framework. Discovery, then validation, rather than simply taking the results others have already discovered and validating them. This research will address the case of North American organizations' adoption of blockchain technology. Formally stated, this research aims to answer the following questions:

- What are the barriers contributing to the low levels of organizational adoption of blockchain technology?

- What are the drivers pushing organizational adoption of blockchain technology?

This research contributes to the technology adoption literature and blockchain technology literature in multiple ways. A new theoretical framework of blockchain technology adoption is presented. The framework supports and validates four factors influencing blockchain adoption; perceived interoperability, perceived data quality, perceived lack of technological knowledge and perceived technological volatility. An extensive literature review has not revealed a prior study that has considered how the volatility of a technology influences organizational adoption decisions, opening up new research opportunities and expanding the area of thought for technology adoption. In addition, a new empirically validated scale is developed to measure an organization's perception of a technology's volatility, which allows future researchers to accurately measure the construct. Furthermore, to develop the framework, a mixed methodology, in the form of two studies, was used. Study 1, consisted of multiple qualitative case studies in the form of 25 interviews with 23 different organizations. This was to discover the factors from primary data as opposed to secondary sources and to enhance the quality of the results. Study 2 took a quantitative angle to empirically test the factors discovered with 146 employees from 71 different organizations. This research is the first to employ the above, extensive mixed-method approach to address blockchain technology adoption. Overall, this research contributes to furthering the adoption of blockchain technology and enriching the technological adoption literature.

The findings of this research have a multitude of practical implications for a variety of audiences. The core beneficiaries include organizations currently adopting blockchain, those considering adoption, organizations developing blockchain solutions for organizations other than 
themselves, firms providing consulting services for blockchain technology and academic researchers studying either the adoption of blockchain itself or other emerging technology.

The remainder of this thesis is organized as follows. Chapter 1 provides a literature review consisting of three parts; an overview of blockchain technology, a review of antecedent blockchain adoption studies, and a discussion of the theoretical base of this thesis. Chapter 2 outlines the mixed method used in this research. It begins with a review of the qualitative methodology and presents the results from this half of the research. It then transitions to the second half of this research to present the quantitative methodology and results. Chapter 3 provides a discussion of the results, which is followed by Chapter 4 consisting of the theoretical and practical implications. Next, Chapter 5 offers the limitations and future research opportunities. The thesis ends with Chapter 6, the conclusion.

In addition to the research at hand, Appendix F provides additional research, conducted during the same time as this master's thesis, regarding blockchain patenting and patent strategy. The paper, titled Innovation Within Networks - Patent Strategies for Blockchain Technology, provides an overview of blockchain patenting trends and outlines an exploratory framework of patenting strategies for blockchain technology. Although the focus is not directly on blockchain's adoption factors, understanding a technology's patent landscape, including patent strategies, helped inform the research at hand of the blockchain technology adoption factors. In addition, patenting information can help organizations position themselves regarding their innovation and provide insights about a technology's future direction. It can also be used to aid organizations when making adoption decisions and therefore is highly relevant for blockchain technology adoption (cf. Mashatan, Dehghani, \& Kennedy, 2020). 
Chapter 1 - Literature Review 
The following literature review is organized into three parts; an overview of blockchain technology, an extensive review of antecedent blockchain adoption studies, and a discussion of this study's theoretical background.

\subsection{Overview of Blockchain Technology}

Blockchain technology was initially developed as a solution to the double spend problem found when using digital currencies (Nakamoto, 2008). Over the past 11 years, the blockchain concept has been researched heavily in academia, resulting in the rapid evolution of the technology. Numerous definitions have been proposed in the literature, (summarized in Table 1) all pointing to a similar idea. The research at hand defines blockchain as a novel form of an appendonly cryptographically linked-list of blocks stored on a public or private network.

\begin{tabular}{|l|l|l|}
\hline Author & Year & Definition \\
\hline Nakamoto & 2008 & $\begin{array}{l}\text { A peer-to-peer network for direct transactions in a trust-less environment as a } \\
\text { solution to the double spend problem, made possible by using a distributed } \\
\text { timestamp server which generates computational proofs of the network's } \\
\text { transactions in chronological order. }\end{array}$ \\
\hline Swan & 2015 & $\begin{array}{l}\text { A blockchain is a public ledger of all Bitcoin transactions that stands as trust-less } \\
\text { proof mechanism of all the transactions on the network. }\end{array}$ \\
\hline $\begin{array}{l}\text { Yli-Huumo, Ko, } \\
\text { Choi, Park, \& } \\
\text { Smolander }\end{array}$ & 2016 & $\begin{array}{l}\text { Blockchain is a distributed database, which maintains an unceasingly expanding } \\
\text { list of data records that are confirmed by the members in the network. The } \\
\text { information about every transaction ever completed is recorded in the public } \\
\text { ledger. }\end{array}$ \\
\hline $\begin{array}{l}\text { Kshetri } \\
\text { \& Scarfone }\end{array}$ & 2017 & $\begin{array}{l}\text { A blockchain is a data structure that allows for the creation of a tamper-proof } \\
\text { digital ledger of transactions and the sharing of the transactions in a network. }\end{array}$ \\
\hline Li et al. & 2018 & $\begin{array}{l}\text { Blockchains are tamper evident and resistant digital ledgers operating in a } \\
\text { distributed fashion (no central database) usually without a central governing } \\
\text { authority. }\end{array}$ \\
\hline Hughes et al. & 2019 & $\begin{array}{l}\text { Blockchain technology is a distributed data structure that is capable of holding } \\
\text { information such as transactions and records that is mimicked and common } \\
\text { between members of the blockchain network. }\end{array}$ \\
\hline
\end{tabular}

Table 1 - Evolution of Blockchain Definitions

At its core, a blockchain network consists of distributed nodes using a common communication medium and protocol, which all store their own complete copy of the blockchain (Wang, Han, \& Beynon-Davies, 2019). Transaction requests are made and distributed across the network of nodes (Zamani, He, \& Phillips, 2018) and authorized using cryptographic digital signatures to ensure nodes have permission for a transaction (Hughes et al., 2019). Digital signatures use a mathematically bound pair of public and private keys for various functions. With blockchain 
technology, public keys are used to create wallet addresses and private keys are used for the authorization of transactions (Narayanan et al., 2016). Transactions can be transfers of financial value or code representing a smart contract (Makhdoom, Abolhasan, Abbas, \& Ni, 2019). They can also be used as a registry to record digitized assets (Wang, Wang, Singgih, \& Rit, 2019). When transactions are propagated to the network, they are received by all nodes, who perform verification according to pre-defined rules about the transaction structure and activity $(\mathrm{Li}$, Greenwood, \& Kassem, 2019).

Specialized nodes known as miners collect the validated transactions in the network, perform their own verification and add the transactions to blocks (Zamani et al., 2018). Within a block, transactions are hashed and stored as Merkle hash trees (Narayanan et al., 2016). With a blockchain network there must exist a method of achieving consensus on the next block of transactions. The consensus protocol of Bitcoin is known as the proof-of-work (PoW) mechanism (Nakamoto, 2008). With the PoW mechanism, the miners attempt to solve a computationally difficult mathematical problem as a form of consensus to verify transactions, ensure their immutability, and reach an agreement on their order (Wang et al., 2019a; Makhdoom et al., 2019; Zamani et al., 2018). The computationally difficult mathematical problem for the PoW involves the computation of a cryptographic hash function by selecting a nonce so that the calculated hash begins with a specified number of zeros (Nakamoto, 2008; Makhdoom et al., 2019). When a miner solves the PoW, the verified block is sent to all other nodes on the network for their own verification (Zamani et al., 2018). Once the network agrees that the block is valid, it is time stamped, added to the chain of blocks and cryptographically linked to its processor block (Li et al. 2019; Zamani et al., 2018). When a block is added to the chain, it cannot be altered by a single actor (Wang et al., 2019b). Finally, when a new block is added to the blockchain, all nodes on the network update their local copies of the blockchain ensuring everyone is operating with the same copy (Zamani et al., 2018).

Although the PoW mechanism works, it has several drawbacks including high latency, computational intensity and energy costs (Makhdoom et al., 2019). As such, other means of achieving consensus have been developed. For example, the proof-of-stake (PoS) mechanism determines mining eligibility (who determines the next block) based on the number of coins owned over a period of time (Makhdoom et al., 2019). Other examples of consensus mechanisms include 
delegated proof-of-stake (DPoS), proof-of-activity, proof-of-authority (PoA), proof-of-elapsed time (PoET), proof-of-burn (PoB), and the list continues to grow (Makhdoom et al., 2019).

As a final note on blockchains, several different types have been developed. The distinction between them is largely based on the permissions (access rights) on the network but other distinctions exist such as level of decentralization, privacy, anonymity, and method of achieving consensus (which creates speed, cost and scalability differences). The three types are public, private and hybrid blockchains (Yaga et al., 2018; Makhdoom et al., 2019).

\subsection{Antecedent Studies of Blockchain Adoption}

To situate this research and provide a comprehensive background on blockchain adoption, an extensive literature review of blockchain adoption studies was performed. Several extensive literature reviews have been performed within the blockchain body of knowledge (Yli-Huumo et al., 2016; Wang et al., 2019b; Li et al., 2019b; Hughes et al., 2019), but a review of the literature shows none have been done regarding blockchain adoption studies. One main source was used to gather papers; the Ryerson University library archive which is connected to 346 unique electronic databases. Search terms consisted of relevant terminology and the inclusion of well-known technology adoption theories. The following search term combinations were used:

- Blockchain and Adoption

- Blockchain and Acceptance

- Distributed Ledger Technology (DLT) and Adoption

- DLT and Acceptance

- Blockchain and Technology Acceptance Model (TAM) (Davis, 1989)

- DLT and TAM

- Blockchain and Unified Theory of Acceptance and Use of Technology (UTAUT) (Venkatesh, Morris, Davis, \& Davis, 2003)

- $\quad$ DLT and UTAUT

- Blockchain and Diffusion of Innovation Theory (DOI) (Rogers, 1962; Rogers, 2003)

- DLT and DOI

- Blockchain and TOE Framework (Tornatzky \& Fleischer, 1990)

- DLT and TOE Framework 
- Blockchain and Adoption and Factors

- DLT and Adoption and Factors

- Blockchain and Adoption and Drivers

- Blockchain and Adoption and Barriers

- DLT and Adoption and Drivers

- DLT and Adoption and Barriers

- Blockchain and Usage Intentions

- DLT and Usage Intentions

- Blockchain and Adoption Framework

- DLT and Adoption Framework

- Factors Influencing and Blockchain Adoption

- Factors Influencing and DLT Adoption

The literature considered was from January 2018 to December 2019 and yielded 871 peerreviewed publications. A detailed analysis revealed 239 duplicates across sources, which were synthesized, leaving 632 unique documents. Article titles and abstracts were read to remove irrelevant results and discover the true adoption studies. A multitude of papers simply happened to contain some of the relevant search terms but were not related to blockchain adoption. Many papers outline the benefits and challenges of using blockchain technology, which may be construed as adoption factors; however, these studies are not considered as part of this extensive literature review, as they are not directly identifying adoption factors. That is, unless the study identifies challenges and benefits specifically for adoption, rather than blockchain itself. In addition, several studies were discovered, which analyzed the factors influencing the adoption of cryptocurrencies. These studies were also not considered, as cryptocurrencies are too specific and a single function of a blockchain and are more of a focus for individual adoption as opposed to organizational adoption. The factors from these studies would not be representative of blockchain technology as a whole. Furthermore, some studies are theoretical in nature, meaning they do not use a direct qualitative or quantitative methodology. These studies were also not considered. Based on the above, to be considered as a blockchain adoption study, a qualitative or quantitative method needed to be used (or both), the focus needed to be on blockchain as a whole and the study must be in the context of adoption. After careful evaluation, a total of 24 studies were selected. Table 2 summarizes the antecedent blockchain adoption studies. 


\begin{tabular}{|c|c|c|c|c|c|c|}
\hline No. & Authors & Theory & Factors & $\begin{array}{l}\text { Sample Size/ } \\
\text { Analysis } \\
\text { Approach }\end{array}$ & Sector & Method \\
\hline 1 & $\begin{array}{l}\text { Kamble, } \\
\text { Gunasekaran } \\
\text { \& Arha } \\
\text { (2019) }\end{array}$ & $\begin{array}{l}\text { TAM, } \\
\text { Technology } \\
\text { Readiness } \\
\text { Index (TRI) } \\
\text { and The } \\
\text { Theory of } \\
\text { Planned } \\
\text { Behaviour } \\
\text { (TPB) }\end{array}$ & $\begin{array}{l}\text { TRI Constructs: } \\
\text { - Insecurity } \\
\text { - Discomfort } \\
\text { TAM Constructs: } \\
\text { - Perceived Usefulness } \\
\text { - Perceived Ease of Use } \\
\text { - Attitude } \\
\text { TPB Constructs: } \\
\text { - Perceived Behavioural } \\
\text { Control } \\
\text { - Subjective Norm } \\
\text { - Behavioural Intention to } \\
\text { Adopt }\end{array}$ & $\begin{array}{l}\text { Survey of } 181 \\
\text { Supply Chain } \\
\text { Practitioners } \\
\text { Structured } \\
\text { Equation } \\
\text { Modeling } \\
\text { (SEM) }\end{array}$ & $\begin{array}{l}\text { Supply } \\
\text { Chain } \\
\text { Managem } \\
\text { ent in } \\
\text { India }\end{array}$ & Quant \\
\hline 2 & $\begin{array}{l}\text { Queiroz \& } \\
\text { Fosso } \\
\text { Wamba } \\
(2019)\end{array}$ & $\begin{array}{l}\text { Modified } \\
\text { UTAUT }\end{array}$ & $\begin{array}{l}\text { - Performance Expectancy } \\
\text { - Social Influence } \\
\text { - Facilitating Conditions } \\
\text { - Blockchain Transparency } \\
\text { - Trust of Supply Chain } \\
\text { Stakeholders } \\
\text { - Behavioural Intention } \\
\text { - Behavioural Expectation }\end{array}$ & $\begin{array}{l}\text { Survey of } 394 \\
\text { Supply Chain } \\
\text { Professionals } \\
\text { Structured } \\
\text { Equation } \\
\text { Modeling } \\
\text { (SEM) }\end{array}$ & $\begin{array}{l}\text { Logistics } \\
\text { and } \\
\text { Supply } \\
\text { Chain in } \\
\text { India and } \\
\text { the United } \\
\text { States of } \\
\text { America } \\
\text { (USA) }\end{array}$ & Quant \\
\hline 3 & $\begin{array}{l}\text { Supranee \& } \\
\text { Rotchanakit } \\
\text { umnuai } \\
\text { (2017) }\end{array}$ & N/a & $\begin{array}{l}\text { Organizational Power: } \\
\text { - Mediated Power } \\
\text { - Non-Mediated Power } \\
\text { IT Assimilation: } \\
\text { - Relational Mechanism } \\
\text { - Organizational Pressure } \\
\text { - Organizational Inertia } \\
\text { Perceived Benefit } \\
\text { - Inter-Organizational Trust } \\
\text { - Inter-Organizational } \\
\text { Relationships } \\
\text { - Intention to Adopt }\end{array}$ & $\begin{array}{l}\text { Survey of } 261 \\
\text { Executives } \\
\text { and Practical } \\
\text { Staff in the } \\
\text { Automotive } \\
\text { Industry } \\
\text { Multiple } \\
\text { Regression }\end{array}$ & $\begin{array}{l}\text { Automoti } \\
\text { ve Supply } \\
\text { Chain in } \\
\text { Thailand }\end{array}$ & Quant \\
\hline 4 & $\begin{array}{l}\text { Wanitcharak } \\
\text { khakul \& } \\
\text { Rotchanakit } \\
\text { umnuai } \\
\text { (2017) }\end{array}$ & $\begin{array}{l}\text { Developed } \\
\text { from } \\
\text { multiple } \\
\text { adoption } \\
\text { theories } \\
\text { (UTAUT, } \\
\text { UTAUT2, } \\
\text { TAM, and } \\
\text { IDT) and } \\
\text { Ad-hoc } \\
\text { Constructs }\end{array}$ & $\begin{array}{l}\text { - Perceived Usefulness } \\
\text { - Relative Advantage } \\
\text { - Ability } \\
\text { - Integrity } \\
\text { - Security and Privacy } \\
\text { - Performance Expectancy } \\
\text { - Trust } \\
\text { - Risk } \\
\text { - Intention to Adopt }\end{array}$ & $\begin{array}{l}\text { Survey of } 149 \\
\text { Medical } \\
\text { Patients, } \\
\text { Physicians, } \\
\text { Nurses, } \\
\text { Pharmacists } \\
\text { and Officers } \\
\text { Multiple } \\
\text { Regression }\end{array}$ & $\begin{array}{l}\text { Healthcar } \\
\text { e in } \\
\text { Thailand }\end{array}$ & Quant \\
\hline 5 & Ryu (2018) & $\begin{array}{l}\text { The Theory } \\
\text { of Reasoned } \\
\text { Action }\end{array}$ & $\begin{array}{l}\text { - Economic Benefit } \\
\text { - Seamless Transaction } \\
\text { - Convenience }\end{array}$ & $\begin{array}{l}\text { Survey of } 243 \\
\text { of Fintech } \\
\text { Users }\end{array}$ & $\begin{array}{l}\text { Finance } \\
\text { Industry }\end{array}$ & Quant \\
\hline
\end{tabular}




\begin{tabular}{|c|c|c|c|c|c|c|}
\hline No. & Authors & Theory & Factors & $\begin{array}{l}\text { Sample Size/ } \\
\text { Analysis } \\
\text { Approach }\end{array}$ & Sector & Method \\
\hline & & $\begin{array}{l}\text { (TRA), Net } \\
\text { Valance } \\
\text { Theory and } \\
\text { the Benefit } \\
\text { Risk } \\
\text { Framework }\end{array}$ & $\begin{array}{l}\text { - Financial Risk } \\
\text { - Legal Risk } \\
\text { - Security Risk } \\
\text { - Operational Risk } \\
\text { - Perceived Benefit } \\
\text { - Perceived Risk } \\
\text { - User Type } \\
\text { - Fintech Continuance } \\
\text { Intention }\end{array}$ & SEM & $\begin{array}{l}\text { in South } \\
\text { Korea }\end{array}$ & \\
\hline 6 & $\begin{array}{l}\text { Wong, } \\
\text { Leong, Hew, } \\
\text { Tan, \& Ooi } \\
(2019)\end{array}$ & $\begin{array}{l}\text { TOE, } \\
\text { UTAUT, } \\
\text { and TAM }\end{array}$ & $\begin{array}{l}\text { - Relative Advantage } \\
\text { - Complexity } \\
\text { - Upper Management Support } \\
\text { - Cost } \\
\text { - Market Dynamics } \\
\text { - Competitive Pressure } \\
\text { - Regulatory Support } \\
\text { - Behavioural Intention }\end{array}$ & $\begin{array}{l}\text { Survey of } 194 \\
\text { Small to } \\
\text { Medium } \\
\text { Enterprises } \\
\text { (SMEs) } \\
\text { SEM }\end{array}$ & $\begin{array}{l}\text { Adoption } \\
\text { of } \\
\text { Blockchai } \\
\mathrm{n} \text { in } \\
\text { Operation } \\
\mathrm{s} \text { and } \\
\text { Supply } \\
\text { Chain } \\
\text { Managem } \\
\text { ent } \\
\text { Among } \\
\text { Malaysian } \\
\text { SMEs }\end{array}$ & Quant \\
\hline 7 & Yang (2019) & $\begin{array}{l}\text { Modified } \\
\text { TAM }\end{array}$ & $\begin{array}{l}\text { Applications: } \\
\text { - Customs Clearance and } \\
\text { Management } \\
\text { - Digitalizing and Easing } \\
\text { Paperwork } \\
\text { - Tracking and Tracing } \\
\text { Future Improvements: } \\
\text { - Standardization and } \\
\text { Platform Development } \\
\text { - Business Model and } \\
\text { Regulation } \\
\text { - Intention to Use }\end{array}$ & $\begin{array}{l}\text { Survey of } 121 \\
\text { Maritime } \\
\text { Organizations } \\
\text { Hierarchical } \\
\text { Regression } \\
\text { Analysis }\end{array}$ & $\begin{array}{l}\text { Maritime } \\
\text { Port } \\
\text { Corporati } \\
\text { ons, } \\
\text { Shipping } \\
\text { Companie } \\
\text { s, } \\
\text { Shipping } \\
\text { Agencies, } \\
\text { and } \\
\text { Shipping } \\
\text { Forwarder } \\
\text { s Engaged } \\
\text { in } \\
\text { Maritime } \\
\text { Shipping } \\
\text { Operation } \\
\text { s in } \\
\text { Taiwan }\end{array}$ & Quant \\
\hline 8 & $\begin{array}{l}\text { Thiruchelva } \\
\text { m, } \\
\text { Mughisha, } \\
\text { Shahpasand, } \\
\text { \& Bamiah } \\
\text { (2019) }\end{array}$ & $\begin{array}{l}\text { Modified } \\
\text { TAM }\end{array}$ & $\begin{array}{l}\text { Blockchain Efficiency as a } \\
\text { factor of: } \\
\text { - Market Access } \\
\text { - Premium Pricing } \\
\text { - Traceability and Reliability } \\
\text { - Transparency and Fair } \\
\text { Trade } \\
\text { - Sustainability } \\
\text { TAM factors and } \\
\text { Dependent Variables: }\end{array}$ & $\begin{array}{l}\text { Survey of } 66 \\
\text { Brundi } \\
\text { Coffee } \\
\text { Industry } \\
\text { Professionals } \\
\text { Quantitative } \\
\text { Analysis } \\
\text { (Descriptive } \\
\text { Statistics and } \\
\text { Percentages }\end{array}$ & $\begin{array}{l}\text { Coffee } \\
\text { Industry } \\
\text { in Brundi } \\
\text { Africa }\end{array}$ & Quant \\
\hline
\end{tabular}




\begin{tabular}{|c|c|c|c|c|c|c|}
\hline No. & Authors & Theory & Factors & $\begin{array}{l}\text { Sample Size/ } \\
\text { Analysis } \\
\text { Approach }\end{array}$ & Sector & Method \\
\hline & & & $\begin{array}{l}\text { - Perceived Usefulness } \\
\text { - Perceived Ease of use } \\
\text { - Attitude Toward } \\
\text { Blockchain } \\
\text { - Behavioural Intention to } \\
\text { Use } \\
\text { - Actual Use }\end{array}$ & $\begin{array}{l}\text { to Build a } \\
\text { Model }\end{array}$ & & \\
\hline 9 & $\begin{array}{l}\text { Hoxha \& } \\
\text { Sadiku } \\
\text { (2019) }\end{array}$ & N/a & $\begin{array}{l}\text { - Increase of Data } \\
\text { Availability } \\
\text { - Reduction of Information } \\
\text { Asymmetry } \\
\text { - Easy Verification of } \\
\text { Transactions } \\
\text { - Comprehensibility of the } \\
\text { Transaction } \\
\text { - Data Accuracy and } \\
\text { Reliability } \\
\text { - Data Interoperability } \\
\text { - Exclusion of False } \\
\text { - Information from } \\
\text { Contractual Information } \\
\text { - High Security Encryption } \\
\text { - Cost Reduction Through } \\
\text { Exclusion of Intermediaries } \\
\text { - Contract Conclusion with } \\
\text { Reasonable Fee } \\
\text { - Cost Reduction due to - } \\
\text { Process Efficiency } \\
\text { - Intention to Adopt } \\
\text { Blockchain } \\
\text { - Practical Implementation }\end{array}$ & $\begin{array}{l}\text { Survey of } \\
1050 \text { Real } \\
\text { Estate } \\
\text { Transaction } \\
\text { System Users } \\
\text { Factor } \\
\text { Analysis }\end{array}$ & $\begin{array}{l}\text { Real } \\
\text { Estate } \\
\text { Transactio } \\
\text { ns in } \\
\text { Kosovo }\end{array}$ & Quant \\
\hline 10 & $\begin{array}{l}\text { Kamblea, } \\
\text { Gunasekaran } \\
\text { b, \& } \\
\text { Sharmaa } \\
\text { (2019) }\end{array}$ & N/a & $\begin{array}{l}\text { Driving Enablers } \\
\text { - Anonymity and Privacy } \\
\text { - Decentralized Database } \\
\text { - Reduced Transaction Cost } \\
\text { - Reduced Settlement Lead } \\
\text { Times } \\
\text { - Secured Database } \\
\text { - Shared Database } \\
\text { - Smart Contracts } \\
\text { Autonomous Enablers } \\
\text { Linkage Enablers } \\
\text { Dependent Enablers } \\
\text { - Decentralized Database } \\
\text { - Immutability } \\
\text { - Improved Risk } \\
\text { Management } \\
\text { - Provenance } \\
\text { - Traceability } \\
\text { - Transparency }\end{array}$ & $\begin{array}{l}\text { Data from the } \\
\text { Literature and } \\
\text { Validated by } \\
\text { Experts } \\
\text { (Academics, } \\
\text { Practitioners } \\
\text { and Senior } \\
\text { Managers } \\
\text { from varying } \\
\text { backgrounds) } \\
\text { Interpretive } \\
\text { Structural } \\
\text { Modelling } \\
\text { (ISM) and } \\
\text { Decision- } \\
\text { Making Trial } \\
\text { and } \\
\text { Evaluation } \\
\text { Laboratory } \\
\text { (DEMATEL) }\end{array}$ & $\begin{array}{l}\text { Agricultur } \\
\text { e Supply } \\
\text { Chain in } \\
\text { India }\end{array}$ & Quant \\
\hline
\end{tabular}




\begin{tabular}{|c|c|c|c|c|c|c|}
\hline No. & Authors & Theory & Factors & $\begin{array}{l}\text { Sample Size/ } \\
\text { Analysis } \\
\text { Approach }\end{array}$ & Sector & Method \\
\hline 11 & $\begin{array}{l}\text { Benbunan- } \\
\text { Fich } \\
\text { \&Castellano } \\
\text { s (2018) }\end{array}$ & $\begin{array}{l}\text { Peled's } \\
\text { Framework } \\
- \text { A } \\
\text { Network- } \\
\text { Coalition- } \\
\text { Institution } \\
\text { Model with } \\
\text { One Added } \\
\text { Construct - } \\
\text { Information } \\
\text { System } \\
\text { Readiness }\end{array}$ & $\begin{array}{l}\text { Information System } \\
\text { Readiness Includes Factors } \\
\text { such as: } \\
\text { - Technological } \\
\text { Expertise } \\
\text { - Information System } \\
\text { Infrastructure } \\
\text { - Level of Digitization } \\
\text { - Availability of } \\
\text { Technological Partner } \\
\text { - Adequacy of Business } \\
\text { Processes } \\
\text { - Ability to Overcome } \\
\text { Resistance } \\
\text { - Legal/Regulatory/Political } \\
\text { Issues } \\
\text { - Sophistication of Processes }\end{array}$ & $\begin{array}{l}\text { Case Study - } \\
\text { in the Form } \\
\text { of Two } \\
\text { Unstructured } \\
\text { Interviews } \\
\text { with the } \\
\text { Liaison } \\
\text { Between } \\
\text { Factom and } \\
\text { the Honduran } \\
\text { Government } \\
\text { Content } \\
\text { Analysis of } \\
\text { interviews }\end{array}$ & $\begin{array}{l}\text { Land and } \\
\text { Property } \\
\text { Registry } \\
\text { in } \\
\text { Honduras } \\
\text { and } \\
\text { Georgia }\end{array}$ & Qual \\
\hline 12 & $\begin{array}{l}\text { Gausdal, } \\
\text { Czachorows } \\
\text { ki, \& } \\
\text { Solesvik } \\
(2018)\end{array}$ & N/a & $\begin{array}{l}\text { Blockchain } \\
\text { Innovation/Adoption } \\
\text { Drivers: } \\
\text { - Reducing Cost } \\
\text { - Regulation Compliance } \\
\text { - Information Intensity of } \\
\text { Industry } \\
\text { - Efficiency } \\
\text { Blockchain } \\
\text { Innovation/Adoption } \\
\text { Barriers: } \\
\text { - Low Cost Industry } \\
\text { Orientation } \\
\text { - Slow Internet Speeds } \\
\text { - Current Low Level of } \\
\text { Digital Diffusion in the } \\
\text { Industry } \\
\text { - Reluctance to Invest due to } \\
\text { Perceived Risk } \\
\text { - Lack of Innovation } \\
\text { Leadership } \\
\text { - Organizational Culture } \\
\text { - The Engineering and } \\
\text { Installation Technology- } \\
\text { Oriented Culture with a Low } \\
\text { Focus on Efficient Business } \\
\text { Processes }\end{array}$ & $\begin{array}{l}\text { Case Study - } \\
\text { in the Form } \\
\text { of Seven } \\
\text { Unstructured } \\
\text { Interviews } \\
\text { with Four } \\
\text { with Offshore } \\
\text { Operators and } \\
\text { Three with } \\
\text { Suppliers } \\
\text { Content } \\
\text { Analysis of } \\
\text { interviews }\end{array}$ & $\begin{array}{l}\text { The } \\
\text { Norwegia } \\
\text { n Offshore } \\
\text { Industry }\end{array}$ & Qual \\
\hline 13 & $\begin{array}{l}\text { Holotiuk \& } \\
\text { Moormann } \\
\text { (2018) }\end{array}$ & $\begin{array}{l}\text { Modified } \\
\text { TOE } \\
\text { Framework }\end{array}$ & $\begin{array}{l}\text { Technology Factors: } \\
\text { - Prototype Difficulty } \\
\text { - Efficiency Gains } \\
\text { - Implementation Difficulty } \\
\text { - Role of Information } \\
\text { Technology }\end{array}$ & $\begin{array}{l}\text { Interviews } \\
\text { with } 11 \\
\text { Blockchain } \\
\text { Experts } \\
\text { Collection of } \\
\text { Secondary }\end{array}$ & $\begin{array}{l}\text { German } \\
\text { Financial } \\
\text { Industry }\end{array}$ & Qual \\
\hline
\end{tabular}




\begin{tabular}{|c|c|c|c|c|c|c|}
\hline No. & Authors & Theory & Factors & $\begin{array}{l}\text { Sample Size/ } \\
\text { Analysis } \\
\text { Approach }\end{array}$ & Sector & Method \\
\hline & & & $\begin{array}{l}\text { - Interplay of Information } \\
\text { Technology and Business } \\
\text { Organization Factors: } \\
\text { - Need for a Separate Entity } \\
\text { within the Organization } \\
\text { - Integrating New Ideas } \\
\text { - Informal and Formal } \\
\text { Exchange Information } \\
\text { Exchange/Dissemination } \\
\text { - Existence of Cross- } \\
\text { Functional Teams } \\
\text { - Organization Attitude } \\
\text { People Factors: } \\
\text { - Lack of Talent } \\
\text { - Need for External Partners } \\
\text { - Connection and Exchange } \\
\text { with Fintechs } \\
\text { - Dedicated Partnerships } \\
\text { - Distributed Knowledge / } \\
\text { Knowledge Alignment } \\
\text { - Excitement } \\
\text { - Need for Developers } \\
\text { - Need for Adoption Mindset } \\
\text { - Need for Combine } \\
\text { Knowledge } \\
\text { Project Management } \\
\text { Factors: } \\
\text { - Need Top-down and } \\
\text { Bottom-up Management } \\
\text { Approaches } \\
\text { - Motivation } \\
\text { - Voluntary Participation } \\
\text { - Anchor Responsibility to } \\
\text { Top Management with Little } \\
\text { Knowledge } \\
\text { Environment Factors: } \\
\text { - Need for Standardization } \\
\text { - Need Successful Use Cases } \\
\text { as Examples } \\
\text { - Need for } \\
\text { Internationalization } \\
\text { - High Uncertainty }\end{array}$ & $\begin{array}{l}\text { Data from the } \\
\text { Literature } \\
\text { Content } \\
\text { Analysis of } \\
\text { Interviews } \\
\text { and } \\
\text { Secondary } \\
\text { data }\end{array}$ & & \\
\hline 14 & $\begin{array}{l}\text { Wang, } \\
\text { Chen, \& Xu } \\
\text { (2016) }\end{array}$ & $\begin{array}{l}\text { Modified } \\
\text { Capability } \\
\text { Maturity } \\
\text { Model } \\
\text { (CMM) to } \\
\text { be the } \\
\text { Blockchain }\end{array}$ & $\begin{array}{l}\text { Proposed BCMM, Outlining } \\
\text { Adoption Barriers (and one } \\
\text { benefit) at Varying Stages of } \\
\text { Blockchain Maturity } \\
\text { Stage } 1 \text { - Initial: }\end{array}$ & $\begin{array}{l}\text { Comparative } \\
\text { Analysis to } \\
\text { Propose A } \\
\text { New Model }\end{array}$ & General & Qual \\
\hline
\end{tabular}




\begin{tabular}{|c|c|c|c|c|c|c|}
\hline No. & Authors & Theory & Factors & $\begin{array}{l}\text { Sample Size/ } \\
\text { Analysis } \\
\text { Approach }\end{array}$ & Sector & Method \\
\hline & & $\begin{array}{l}\text { CMM } \\
\text { (BCMM) }\end{array}$ & $\begin{array}{l}\text { - Architecture - Integration } \\
\text { and Design Challenges } \\
\text { - Upgrading Complexity } \\
\text { - Integration - } \\
\text { Interoperability } \\
\text { - Lack of Standardization } \\
\text { Stage } 2 \text { - Repeatable: } \\
\text { - Network Load } \\
\text { - Maintenance - Lack of } \\
\text { Experience } \\
\text { - Storage Needs } \\
\text { - Scalability Needs } \\
\text { - Computational Complexity } \\
\text { Stage 3- Defined: } \\
\text { - Reliability } \\
\text { - Privacy } \\
\text { Stage } 4 \text { - Managed: } \\
\text { - Business Efficiency (the } \\
\text { only positive factor) } \\
\text { - Data Security } \\
\text { - Transaction Security } \\
\text { Stage } 5 \text { - Optimizing: } \\
\text { - None }\end{array}$ & & & \\
\hline 15 & $\begin{array}{l}\text { Wang, } \\
\text { Singgih, } \\
\text { Wang, \& Rit } \\
\text { (2019a) }\end{array}$ & $\begin{array}{l}\text { Sense } \\
\text { Making } \\
\text { Theory }\end{array}$ & $\begin{array}{l}\text { Three Frames Influence } \\
\text { Decisions to Adopt: } \\
\text { - Benefits Frame: } \\
\text { - Improved Visibility } \\
\text { - Secure Information Sharing } \\
\text { - Building Trust } \\
\text { - Operational Improvements } \\
\text { - Applications Frame: } \\
\text { - External Validity and } \\
\text { Traceability } \\
\text { - Simplification, Digitization, } \\
\text { and Optimization of } \\
\text { Operations } \\
\text { - Smart Contracts } \\
\text { - Trust Building } \\
\text { - Disintermediation } \\
\text { - Supply Chain Change } \\
\text { - Challenges Frame: } \\
\text { - Lack of Confidence } \\
\text { - Cultural, Procedural, } \\
\text { Governance, and } \\
\text { Collaboration } \\
\text { - Data Input and Sharing } \\
\text { - Network and }\end{array}$ & $\begin{array}{l}\text { Interviews } \\
\text { with } 14 \\
\text { Supply Chain } \\
\text { Experts } \\
\text { Using the } \\
\text { Delphi Study } \\
\text { Approach } \\
\\
\text { Content } \\
\text { Analysis and } \\
\text { Cognitive } \\
\text { Mapping }\end{array}$ & $\begin{array}{l}\text { Supply } \\
\text { Chain in } \\
\text { the UK, } \\
\text { Switzerlan } \\
\text { d, } \\
\text { Indonesia, } \\
\text { Germany, } \\
\text { Romania, } \\
\text { and } \\
\text { Portugal }\end{array}$ & Qual \\
\hline
\end{tabular}




\begin{tabular}{|c|c|c|c|c|c|c|}
\hline No. & Authors & Theory & Factors & $\begin{array}{l}\text { Sample Size/ } \\
\text { Analysis } \\
\text { Approach }\end{array}$ & Sector & Method \\
\hline & & & $\begin{array}{l}\text { Interoperability } \\
\text { o Cost, Privacy, Legal, and } \\
\text { Security Factors }\end{array}$ & & & \\
\hline 16 & $\begin{array}{l}\text { Angelis \& } \\
\text { Ribeiro da } \\
\text { Silva (2019) }\end{array}$ & $\mathrm{N} / \mathrm{a}$ & $\begin{array}{l}\text { Created a Value Driver } \\
\text { Framework } \\
\text { Value Opportunities } \\
\text { Pushing Adoption: } \\
\text { - Transparency } \\
\text { - Immutability } \\
\text { - Privacy } \\
\text { - Reliability } \\
\text { - Fault Tolerance } \\
\text { - Democratization } \\
\text { - Security } \\
\text { - Risk control } \\
\text { - Tokenization } \\
\\
\text { Value Drivers Pushing } \\
\text { adoption: } \\
\text { - Transaction Cost } \\
\text { - Added Services } \\
\text { - Expanding Organization } \\
\text { Boundaries } \\
\text { - Autonomous Decision- } \\
\text { Making }\end{array}$ & $\begin{array}{l}\text { Qualitative } \\
\text { Trend } \\
\text { Analysis of } \\
\text { Existing } \\
\text { Literature }\end{array}$ & General & Qual \\
\hline 17 & $\begin{array}{l}\text { Batubara, } \\
\text { Ubacht, \& } \\
\text { Janssen } \\
(2018)\end{array}$ & $\begin{array}{l}\text { TOE } \\
\text { Framework }\end{array}$ & $\begin{array}{l}\text { Technological Adoption } \\
\text { Challenges: } \\
\text { - Design Variables } \\
\text { - Immaturity } \\
\text { - Storage Size } \\
\text { - General Application } \\
\text { Platform } \\
\text { - Computation Efficiency } \\
\text { - Flexibility } \\
\text { - Interoperability } \\
\text { - Usability } \\
\text { - Scalability } \\
\text { - Security } \\
\\
\text { Organizational Adoption } \\
\text { Challenges: } \\
\text { - Auditing } \\
\text { - Trust } \\
\text { - Implications } \\
\text { - New Governance Model } \\
\text { - Risk of Error (for complex } \\
\text { business rules) } \\
\text { - Business } \\
\text { Model/Organizational } \\
\text { Transformation }\end{array}$ & $\begin{array}{l}\text { Literature } \\
\text { Review }\end{array}$ & $\begin{array}{l}\text { Blockchai } \\
\mathrm{n} \text { for } \\
\text { Electronic } \\
- \\
\text { Governme } \\
\text { nt }\end{array}$ & Qual \\
\hline
\end{tabular}




\begin{tabular}{|c|c|c|c|c|c|c|}
\hline No. & Authors & Theory & Factors & $\begin{array}{l}\text { Sample Size/ } \\
\text { Analysis } \\
\text { Approach }\end{array}$ & Sector & Method \\
\hline & & & $\begin{array}{l}\text { - Cost Effectiveness } \\
\text { - Organizational Readiness } \\
\\
\text { Environmental Adoption } \\
\text { Challenges: } \\
\text { - Support Infrastructure } \\
\text { - Accessibility } \\
\text { - Acceptability } \\
\text { - Laws and Regulations } \\
\text { Support }\end{array}$ & & & \\
\hline 18 & $\begin{array}{l}\text { Kshetri } \\
(2017)\end{array}$ & DOI Theory & $\begin{array}{l}\text { Characteristics of } \\
\text { Blockchain Technology } \\
\text { Influencing its Adoption: } \\
\text { Relative Advantage: } \\
\text { - Transparency, Fraud, and } \\
\text { Corruption Reduction } \\
\text { - Friction Cost Reduction } \\
\text { Compatibility: } \\
\text { - Corrupt Politician } \\
\text { Resistance } \\
\text { - Complexity } \\
\text { Observability: } \\
\text { - Lower Transaction Cost } \\
\text { - Visibility } \\
\text { - Trialability }\end{array}$ & $\begin{array}{l}\text { Literature } \\
\text { Review }\end{array}$ & $\begin{array}{l}\text { Economic } \\
\mathrm{s} \text { in the } \\
\text { Global } \\
\text { South }\end{array}$ & Qual \\
\hline 19 & $\begin{array}{l}\text { Li et al. } \\
\text { (2019b) }\end{array}$ & N/a & $\begin{array}{l}\text { Developed a Framework - } \\
\text { Socio-Technical } \\
\text { Framework for Blockchain } \\
\text { Implementation } \\
\text { Challenges to } \\
\text { Implementation/Adoption: } \\
\text { - Data Authentication } \\
\text { - Bandwidth / Connectivity } \\
\text { - Smart Contract Coding } \\
\text { - Energy Consumption } \\
\text { - Exchange Rate Volatility } \\
\text { - Interoperability } \\
\text { - Legal Issues } \\
\text { - Malicious Attacks } \\
\text { - Readiness } \\
\text { - Resistance to Change } \\
\text { - Lack of Skills } \\
\text { - Technology State of the } \\
\text { Industry } \\
\text { Opportunities from } \\
\text { Implementation/Adoption: } \\
\text { - Increased Collaboration }\end{array}$ & $\begin{array}{l}\text { Literature } \\
\text { Review } \\
\text { Focus Group } \\
\text { Session with } \\
8 \text { Individuals } \\
\text { from a United } \\
\text { Kingdom } \\
\text { (UK) } \\
\text { University } \\
\text { One Semi- } \\
\text { Structured } \\
\text { Interview } \\
\text { with a Senior } \\
\text { Industry } \\
\text { Member } \\
\text { Content } \\
\text { Analysis of } \\
\text { Interviews } \\
\text { and Focus } \\
\text { Group Data }\end{array}$ & $\begin{array}{l}\text { Constructi } \\
\text { on } \\
\text { Industry } \\
\text { in the UK }\end{array}$ & Qual \\
\hline
\end{tabular}




\begin{tabular}{|c|c|c|c|c|c|c|}
\hline No. & Authors & Theory & Factors & $\begin{array}{l}\text { Sample Size/ } \\
\text { Analysis } \\
\text { Approach }\end{array}$ & Sector & Method \\
\hline & & & $\begin{array}{l}\text { - Digital Twining } \\
\text { - Disintermediation } \\
\text { - Efficiency } \\
\text { - Faster Processes } \\
\text { - Immutability } \\
\text { - Lower Costs } \\
\text { - Proof of Ownership } \\
\text { - Provenance } \\
\text { - Reduction of Human Error } \\
\text { - Smart Contracts } \\
\text { - Societal Benefits } \\
\text { - Traceability/Auditability } \\
\text { - Workflow Improvements }\end{array}$ & & & \\
\hline 20 & $\begin{array}{l}\text { Lacity } \\
(2018)\end{array}$ & N/a & $\begin{array}{l}\text { Adoption Challenges: } \\
\text { - Standardization } \\
\text { - Regulations } \\
\text { - Shared Governance } \\
\text { - Viable Ecosystem }\end{array}$ & $\begin{array}{l}\text { Case Study of } \\
\text { Three } \\
\text { Organizations } \\
\text { representing } \\
\text { the Energy, } \\
\text { Supply Chain } \\
\text { and } \\
\text { Manufacturin } \\
\text { g Sectors }\end{array}$ & $\begin{array}{l}\text { Energy, } \\
\text { Supply } \\
\text { Chain, } \\
\text { and } \\
\text { Manufact } \\
\text { uring } \\
\text { Sectors } \\
\text { (USA) }\end{array}$ & Qual \\
\hline 21 & $\begin{array}{l}\text { Grover, Kar, } \\
\text { Janssen, \& } \\
\text { Ilavarasan } \\
(2019)\end{array}$ & $\begin{array}{l}\text { Modified } \\
\text { TAM }\end{array}$ & $\begin{array}{l}\text { Perceived Usefulness as the } \\
\text { Core Characteristics of } \\
\text { Blockchain such as: } \\
\text { - Immutability } \\
\text { - Decentralization } \\
\text { - Security as a Benefit is } \\
\text { Discussed the most } \\
\text { Perceived Ease of Use as } \\
\text { the Sentiment Scores for } \\
\text { Use Cases such as: } \\
\text { - Initial Coin Offerings } \\
\text { - Smart Contracts } \\
\text { - Initial Coin Offerings are } \\
\text { Discussed the Most } \\
\text { Attitude Towards Use } \\
\text { Measured as Blockchain } \\
\text { Benefits such as: } \\
\text { - Lower Transaction Cost } \\
\text { - Higher Transaction Speed } \\
\text { - Benefits Discussed more } \\
\text { than Drawbacks } \\
\text { External Variables } \\
\text { Measured as Blockchain } \\
\text { Drawbacks such as: } \\
\text { - Power Consumption and } \\
\text { Hardware Cost }\end{array}$ & $\begin{array}{l}\text { Collection of } \\
\text { Twitter Posts } \\
\text { Data Mining } \\
\text { and Content } \\
\text { Analysis of } \\
\text { Twitter posts }\end{array}$ & General & Qual \\
\hline
\end{tabular}




\begin{tabular}{|c|c|c|c|c|c|c|}
\hline No. & Authors & Theory & Factors & $\begin{array}{l}\text { Sample Size/ } \\
\text { Analysis } \\
\text { Approach }\end{array}$ & Sector & Method \\
\hline & & & $\begin{array}{l}\text { - Drawbacks discussed less } \\
\text { than benefits. } \\
\text { - Actual Use }\end{array}$ & & & \\
\hline 22 & $\begin{array}{l}\text { Janssen, } \\
\text { Weerakkod, } \\
\text { Ismagilova, } \\
\text { Sivarajah, \& } \\
\text { Irani (2020) }\end{array}$ & $\begin{array}{l}\text { Koppenjan } \\
\text { and } \\
\text { Groenwegen } \\
\text { 's Institution } \\
\text { Framework }\end{array}$ & $\begin{array}{l}\text { Institutional Factors } \\
\text { - Norms and Cultures } \\
\text { (cultural resistance, } \\
\text { resistance to change, lack of } \\
\text { understanding of blockchain } \\
\text { technology) } \\
\text {-Regulations and Legislations } \\
\text { (need for new law, ability for } \\
\text { law enforcement to deal with } \\
\text { fraudulent activities, policy } \\
\text { makers confusion of Bitcoin } \\
\text { with blockchain technology, } \\
\text { need to deal with taxation, } \\
\text { laws need to consider the } \\
\text { nature of blockchain } \\
\text { technology, and loss of } \\
\text { governmental control) } \\
\text {-Governance (use of an } \\
\text { appropriate governance } \\
\text { framework, and risk of } \\
\text { market manipulation and } \\
\text { unfair practices) } \\
\text { Market Factors } \\
\text { - Market Structure (high } \\
\text { degree of computerization } \\
\text { increases in market volatility } \\
\text { and interconnectedness) } \\
\text { - Contracts and Agreements } \\
\text { (moving existing contract to } \\
\text { new blockchain technology } \\
\text { methodology, lack of clarity } \\
\text { on smart contracts, and } \\
\text { confusion of smart contracts } \\
\text { with e-contracts) } \\
\text { - Business Process (Inability } \\
\text { to aply traditional business } \\
\text { processes for using } \\
\text { blockchain technology and } \\
\text { cost of adoption and } \\
\text { implementation of } \\
\text { blockchain technology for } \\
\text { businesses) } \\
\text { Technical Factors } \\
\text { - Information Exchange and } \\
\text { Transactions (time to process }\end{array}$ & $\begin{array}{l}\text { Literature } \\
\text { Review }\end{array}$ & General & Qual \\
\hline
\end{tabular}




\begin{tabular}{|c|c|c|c|c|c|c|}
\hline No. & Authors & Theory & Factors & $\begin{array}{l}\text { Sample Size/ } \\
\text { Analysis } \\
\text { Approach }\end{array}$ & Sector & Method \\
\hline & & & $\begin{array}{l}\text { transaction, size of the block, } \\
\text { and standardization) } \\
\text { - Distributed Ledger (design } \\
\text { of the system, cybercrime, } \\
\text { and newness) } \\
\text { - Shared Information } \\
\text { (development of standard } \\
\text { infrastructure components) }\end{array}$ & & & \\
\hline 23 & $\begin{array}{l}\text { Sander, } \\
\text { Semeijn, \& } \\
\text { Mahr (2018) }\end{array}$ & N/a & $\begin{array}{l}\text { Survey Results: } \\
\text { Implementing Blockchain as } \\
\text { a Transparent and } \\
\text { Traceability System (TTS) } \\
\text { had a Significant Positive } \\
\text { Relationship with Consumer } \\
\text { Quality Perceptions and } \\
\text { Purchase Decisions } \\
\text { Interview Results: } \\
\text { - Retail Managers Claim } \\
\text { Consumers are Less } \\
\text { Concerned with a TTS and } \\
\text { More Price Conscious About } \\
\text { the Eat they Purchase } \\
\text { - Retailers Also Note that an } \\
\text { Investment in a Blockchain } \\
\text { Based TTS Might Increase } \\
\text { their Image and Reputation } \\
\text { - Government Officials are } \\
\text { Concerned About the Price of } \\
\text { the Blockchain Based TTS } \\
\text { - The Need for Trust in a } \\
\text { Blockchain Based TTS was } \\
\text { Highlighted } \\
\text { - Implementing a Blockchain } \\
\text { Based TTS Requires a } \\
\text { Change in Mindset of } \\
\text { Individuals in the Supply } \\
\text { Chain } \\
\text { - Early Adopters of a } \\
\text { Blockchain Based TTS } \\
\text { Should Receive Significant } \\
\text { Benefits }\end{array}$ & $\begin{array}{l}\text { Semi- } \\
\text { Structured } \\
\text { Interviews } \\
\text { with Seven } \\
\text { Retail } \\
\text { Managers in } \\
\text { Germany and } \\
\text { the } \\
\text { Netherlands, } \\
\text { Four } \\
\text { Government } \\
\text { Officials, and } \\
\text { One 3Ptsp. } \\
\text { Content } \\
\text { Analysis of } \\
\text { Interviews } \\
\text { Survey of } 141 \\
\text { Meat } \\
\text { Consumers } \\
\text { SEM }\end{array}$ & $\begin{array}{l}\text { Produce } \\
\text { Supply } \\
\text { Chain in } \\
\text { Europe } \\
\text { and the } \\
\text { United } \\
\text { Kingdom } \\
\text { (UK) - } \\
\text { Germany, } \\
\text { Netherlan } \\
\text { ds, } \\
\text { Belgium, } \\
\text { Great } \\
\text { Britain }\end{array}$ & Mix \\
\hline 24 & $\begin{array}{l}\text { Altaei, } \\
\text { Barghuthi, } \\
\text { Mahmoud, } \\
\text { Barghuthi, }\end{array}$ & N/a & $\begin{array}{l}\text { Factors Motivating } \\
\text { Adoption/Investment: } \\
\text { - Security and Data } \\
\text { Protection } \\
\text { - Record Keeping }\end{array}$ & $\begin{array}{l}\text { Survey of } 25 \\
\text { Chief } \\
\text { Information } \\
\text { Officers }\end{array}$ & $\begin{array}{l}\text { General - } \\
\text { United } \\
\text { Arab } \\
\text { Emirates }\end{array}$ & Mix \\
\hline
\end{tabular}




\begin{tabular}{|c|c|c|c|c|c|c|}
\hline No. & Authors & Theory & Factors & $\begin{array}{l}\text { Sample Size/ } \\
\text { Analysis } \\
\text { Approach }\end{array}$ & Sector & Method \\
\hline & $\begin{array}{l}\text { \& Said } \\
\text { (2019) }\end{array}$ & & $\begin{array}{l}\text { - Data Reliability } \\
\text { - Regulations } \\
\text { - International Trend } \\
\text { - Innovation } \\
\text { - Smart Online Services } \\
\text { - Demanded Services } \\
\text { - High Customer Flows } \\
\text { - Long Processing Times } \\
\text { - Scattered Services } \\
\text { - Low Efficiency } \\
\text { - Smart Contracts } \\
\text { Adoption Challenges: } \\
\text { - Lack of Blockchain Experts } \\
\text { - Novelty of the Technology } \\
\text { - Lack of Understanding } \\
\text { - Lack of Industry Standards } \\
\text { - Regulatory Constraints } \\
\text { - Privacy and Security } \\
\text { Considerations }\end{array}$ & $\begin{array}{l}\text { Content } \\
\text { Analysis of } \\
\text { Survey Data } \\
\text { Quantitative } \\
\text { Analysis of } \\
\text { Survey Data }\end{array}$ & & \\
\hline
\end{tabular}

Table 2 - Antecedent Blockchain Adoption Studies

Several gaps have been identified based on the extensive literature review. First, although some literature exists regarding blockchain adoption, there is not enough to achieve a true understanding of the adoption phenomena to promote ubiquitous adoption. Folkinshteyn \& Lennon (2016) made note of the absence of theory development for blockchain adoption in 2016 and little empirical adoption literature has been created since. Recent papers are still making note of the lack of blockchain adoption literature (Janssen, et al., 2020). Indeed, as extensive as blockchain literature is, adoption research has been neglected. Second, many papers focus on the adoption of cryptocurrencies, such as Bitcoin (Almarashdeh, 2018; Jonker, 2019), as a financial instrument. However, cryptocurrencies are only one function of a blockchain and studies in this manner do not provide a comprehensive view of blockchain technology's adoption. Moreover, the literature contains several studies, which perform literature reviews to identify the adoption factors, often phrased as challenges or opportunities (Taufiq, Meyliana, Hidayanto, \& Prabowo, 2018). As blockchain technology matures, the adoption landscape changes, requiring additional studies to clarify the adoption factors. There is a need to discover these factors from primary data rather than from previous and possibly outdated research and have a study focused on blockchain as a whole. Third, the classical adoption theories such as UTAUT and TAM have been used in multiple studies of blockchain adoption, but the TOE Framework has only been used in two. 
Batubara et al. (2018) performed a literature review, and organized the adoption factors according to the TOE Framework. They did not derive the factors from empirical data. Holotiuk \& Moormann (2018) used a modified version of the TOE Framework, however they had a small sample size and limited their study to the financial industry. There is a need to extend the TOE Framework with a larger sample and different organizational classifications, to study blockchain technology's adoption factors in an explorative approach. In addition, there is a lack of blockchain adoption studies considering the North American context. Furthermore mixed-method research allows for a more complete and detailed, end to end, understanding of the phenomenon being studied and allows for both theory building and testing, which is aligned with the goals of this research; to identify and empirically test the factors influencing blockchain technology adoption. Little mixed-method research, beginning with a qualitative identification of the factors followed by quantitative testing of them, exist for blockchain technology adoption. Sander et al. (2018) and Altaei et al. (2019) used a mixed method for their research; however, their mixed-method approach differs from the current research. Both used a qualitative method to identify the factors but they did not use a quantitative method to test them. Finally, few studies have collected data from a sample of organizations representing a multitude of sectors and at varying stages of blockchain adoption. Most analyze a single sector (such as Fintech) and with organizations who have not adopted blockchain technology. Study 1 of this research uses a sample that crosses several sectors and includes both adaptors and non-adaptors of blockchain technology.

\subsection{Theoretical Background}

The technological adoption literature is rich in its theoretical development, presenting researchers with several competing theories that can be used to study a technology adoption phenomenon. Studies within this body of knowledge can be grouped into two broad categories; organizational-level and individual-level (employees and/or customers). Individual-level studies analyze the factors influencing individual customers, employees or any other type of individual users' technology adoption decisions. Examples of theories used to analyze and understand adoption at the individual level include classics such as The Theory of Planned Behaviour (TPB) (Ajzen, 1991), The Theory of Reasoned Action (TRA) (Davis, Bagozzi, \& Warshaw, 1989), TAM, TAM2 (Venkatesh \& Davis, 2000), TAM3 (Venkatesh \& Bala, 2008), UTAUT, and UTAUT2 (Venkatesh, Thong, \& Xu, 2012). Organization-level studies analyze the factors influencing 
organizational-level adoption decisions. Two examples of theories used to analyze and understand adoption at the organizational level are; The TOE Framework and The DOI Theory.

The core theory used for this research is the TOE framework (Tornatzky \& Fleischer, 1990). The TOE framework is described in Tornatzky and Fleischer's (1990) book titled 'The Processes of Technological Innovation'. The book provides a comprehensive description of the whole innovation process from idea development to the adoption and use of the innovation. The TOE framework is used to understand one important section of the innovation process; the manner in which a firm's contexts influence the adoption and implementation of innovations (Baker, 2012). As represented by the three letters in the TOE acronym, the TOE framework analyzes three contextual elements, which influence organizational adoption decisions; the technology, the organization, and the environment (Baker, 2012). The idea is that factors within all three contexts impact organizational adoption decisions; that is, the factors determine if an organization will, or will not, adopt an innovation. The technology context represents the technology an organization is currently using and the technology available to them externally (Baker, 2012). Knowing this information allows an organization to understand the type, scope, and pace of change an innovation will cause. The technology context also allows an organization to understand what types of innovations are available (in the market) for them to implement (Baker, 2012). The organizational context represents the characteristics of a firm such as departmental linking mechanisms, organizational structure (organic vs mechanistic), communication processes, managerial leadership, firm size, and resource availability (Baker, 2012). The organizational context is used to understand if a firm's characteristics promote or hinder the adoption of innovations. The environmental context includes elements external to the organization such as; industry characteristics (competition, growth etc.), the availability of technological service support and the regulatory environment. It is used to identify and understand the impediments and facilitators of organizational innovation external to the firm (Baker, 2012). The TOE framework brings all three of the contextual elements together into a single framework to provide a holistic view of the factors influencing organizational innovation, adoption, and implementation.

As defined by the research question, this research is investigating the factors affecting the adoption of blockchain technology for North American organizations. The focus is on organization adoption rather than individuals and thus, an organizational-level theory is needed. This creates a 
theoretical congruence between the TOE Framework and this research, making the selection of the TOE Framework, as a base theory, appropriate. In addition, a detailed literature review shows numerous studies of technological adoption which have made use of the TOE Framework to study a variety of technology (Tomás, Thomas, \& Oliveira, 2018, Arpaci, Yardimci, \& Turetken 2015; Arpaci, Yardimci, Ozkan, \& Turetken, 2012; Pan \& Jang, 2008; Cui, Zhang, Zhang, \& Huang, 2008; Lin \& Lin, 2008; Chang, Hwang, Hung, Lin, \& Yen, 2007; Lee \& Shim, 2007; Hong \& Zhu, 2006; Zhu \& Kraemer, 2005; Raymond, Bergeron, \& Blili, 2005; Xu, Zhu, \& Gibbs, 2004). This shows the framework has received considerable and consistent empirical support in a variety of domains, further supporting the choice of the TOE framework as a theoretical foundation to discover and organize the factors influencing the adoption of blockchain technology. 
Chapter 2 - Methodology and Results 
The central goal of this research is to develop a theoretical framework of blockchain technology adoption, expanding on the critical factors influencing organizational adoption behaviour. The development of the framework includes both, the identification of the factors and the validation or testing of the factors discovered. To achieve this goal, a mixed-method approach broken down into two studies is used. First, Study 1 involves exploratory multiple-case studies, to discover the adoption factors from primary data collected from North American organizations. This approach was taken due to the lack of empirically validated research toward blockchain technology's adoption. In addition, due to the uniqueness and novelty of blockchain technology, constructs within many existing models of technological adoption are too broad or unrelated, further supporting the need for a qualitative identification of the adoption factors specific to blockchain. Furthermore, since the inception of blockchain technology countless changes have occurred and the technology continues to evolve, stipulating the need for a fresh identification of the factors from organizations actively engaged (considering adoption or actually adopting) with blockchain. In other words, previously identified factors may be outdated, no longer relevant, or inaccurate. Second, Study 2 takes a quantitative angle to empirically validate the qualitative findings and to evaluate the robustness and generalizability of the proposed theoretical framework. This research uses the general guidelines to conducting mixed-method research proposed by Venkatesh, Brown, \& Bala (2013) and DeVellis (2003). Figure 1 provides a high-level depiction of the mixed methodology used for this research. 


\section{Study 1 - Exploratory Multiple-Case Study}

\section{Extensive Literature Review}

- The extensive literature review was to:

a. Identify problems.

b. Understand the gaps in knowledge.

c. Develop a preliminary list of factors (scaling literature).

d. Develop the interview instrument.
- Makes use of an exploratory multiple-case study research design using semi-structured interviews for a detailed examination of the drivers and barriers for blockchain technology's adoption.

- A total of 25 interviews were conducted with 23 unique organizations from 12 different sectors and 4 academic specialists.

- A content analysis (open coding, categorization, and abstraction) was conducted using NVIVO 12.

- The above generated pool of 15 blockchain adoption factors and three sub-factors categorized according to the three TOE contexts.

Study 2 - Quantitative Survey - Pilot Study

- The survey instrument was developed.

- To test the survey instrument's functionality, the response rate and the reliability of the questions were tested with 14 blockchain subject matter experts.

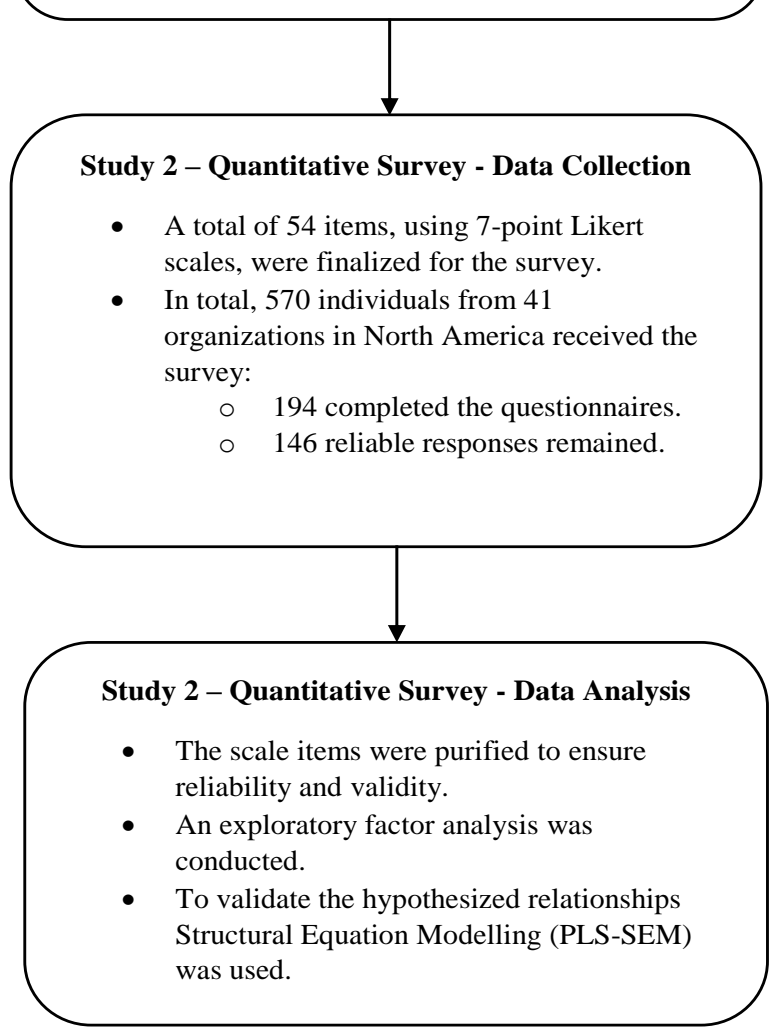

Figure 1 - Mixed Methodology Overview 


\subsection{Study 1 - Qualitative Method - Exploratory Multiple-Case Study}

The following section outlines the qualitative method used for Study 1. It presents the study's design, participant involved for data collection, data analysis and results.

\subsubsection{Design}

To identify the adoption factors for blockchain technology, this research embraced an exploratory multiple-case study research design, which allows for the exploration of unexplored themes (Yin, 2014). Data was collected by conducting semi-structured interviews for an in-depth examination of the drivers and barriers for blockchain technology. Cases were purposefully selected for their market position and popularity (Miles \& Huberman, 1994). Interviews were conducted between January - March 2019 and were done in person or using a virtual method such as Skype, for an average duration of 50 minutes. Interview questions were relatively structured, concentrating on blockchain technology's strategies, practices, benefits, and challenges using principles elaborated and described by previous research (Hughes et al., 2019; Casino, Dasaklis, \& Patsakis, 2019). The interview instrument (see Appendix D) consisted of 9 demographic questions and 16 questions inquiring directly or indirectly about the adoption factors. Finally, to create a record of the data, an audio recording device and a transcription application (Otter.ai) were used.

\subsubsection{Participants}

The sample consisted of a variety of North American organizations. The goal was to cover multiple industries and speak with several different types of organizations to achieve a truly comprehensive view. The sample consisted of blockchain start-ups, blockchain service providers, financial organizations, governmental entities at multiple levels, consulting firms, and large technology providers. The sampled organizations were in varying stages of their blockchain development including: those who have adopted, those considering adoption, and those who have not adopted. The one caveat for this sample is the organization must have at least considered blockchain technology as a possibility or in the case of blockchain service providers and consulting firms, have helped their clients understand and/or implement it. A total of 25 interviews were conducted with 23 unique organizations from 12 different sectors. Convenience sampling was the 
method employed to select the interviewees. The details of each case are summarized in Appendix A.

\subsubsection{Data Analysis and Results}

To analyze the textual data, a content analysis was conducted using NVIVO 12. Content analysis is well suited for the analysis of written, verbal or visual communications and it can be used to derive related categories from raw data (Elo \& Kyngäs, 2008; Cole, 1988). Therefore, it is well suited for the analysis needs of this Study 1. Elo \& Kyngäs (2008) outlined three general phases to conduct content analysis which are used for Study 1: preparation (including the analytic process), organization, and reporting. First comes preparation, which first involves selecting the unit of analysis (Asghar, Cang, \& Yu, 2018). The unit of analysis for Study 1 was the whole interview. In addition, as preparatory work, a cross validation was conducted by listening to recordings and comparing interview transcriptions to ensure accuracy, correct any errors, and clean the data. A final preparatory step was to define what is meant by an 'adoption factor', so it is clear before analysis. Next, with clean data the analytic process was started. According to Braun \& Clarke (2006), the analytic process involves open coding, categorization, and abstraction. As such, the textual data was read multiple times to identify mentions of an adoption factor.

The whole data set was read twice and the main notes for initial ideas were taken at this stage. As many potential codes as possible were documented. Mentions of an adoption factor were highlighted, coded, and organized within NVIVO 12. Once all textual data was analyzed, the list of adoption factors were organized according to similarity and synthesized into well-defined categories and subcategories. Irrelevant codes were discarded. After several revisions of the themes in relation to the collected data, an exploratory framework was produced (see Appendix C). The categories represent the variables in the exploratory framework, which represent blockchains' adoption drivers and barriers. Table 3 outlines the results, defines the factors, provides quotes representative of the factors, includes a count of the times they were mentioned in the transcripts and gives the relative TOE context. 


\begin{tabular}{|c|c|c|c|c|c|}
\hline No. & Name & Definition & Quote & No & $\begin{array}{l}\text { TOE } \\
\text { Context }\end{array}$ \\
\hline 1 & $\begin{array}{l}\text { Perceived } \\
\text { Data Quality }\end{array}$ & $\begin{array}{l}\text { The perceived } \\
\text { attractive } \\
\text { characteristics of the } \\
\text { information systems } \\
\text { output, such as } \\
\text { quality, accuracy, } \\
\text { completeness, } \\
\text { availability and } \\
\text { timeliness (Cheng, } \\
\text { 2014; DeLone \& } \\
\text { McLean, 1992; } \\
\text { Daradkeh, 2018). }\end{array}$ & $\begin{array}{l}\text { 'So, for supply chain where you're going } \\
\text { from producer through a whole bunch of } \\
\text { intermediaries and value-added steps to a } \\
\text { final product, you can use that to make } \\
\text { sure that everything is documented } \\
\text { through the entire process and then that } \\
\text { documentation cannot be undone or } \\
\text { fabricated that's very powerful... } \\
\text { Also more auditable in that you can have } \\
\text { a completely non-repudiable chain that } \\
\text { links transaction a to transaction b to } \\
\text { transaction c, ...Tamper resistant data } \\
\text { structure is fundamental to the value } \\
\text { because you need to have the assurance } \\
\text { that people simply cannot create tokens } \\
\text { on the system that do not are not } \\
\text { grounded in the system... Certainly, } \\
\text { removing a single point of failure is true } \\
\text { because you don't want a system that } \\
\text { runs the global financial world, which is } \\
\text { ever going to fail'. }\end{array}$ & 47 & $\mathrm{~T}$ \\
\hline 2 & $\begin{array}{l}\text { Perceived } \\
\text { Financial Cost } \\
\text { Perceived } \\
\text { Revenue } \\
\text { Cannibalization } \\
\text { - Sub-Factor - } \\
\text { A specific } \\
\text { instance of a } \\
\text { financial cost. }\end{array}$ & $\begin{array}{l}\text { The extent to which } \\
\text { an organization } \\
\text { perceives the } \\
\text { implementation and } \\
\text { use of a new } \\
\text { technology to be } \\
\text { financially and } \\
\text { psychologically costly } \\
\text { (Park, Kim, \& Kwon } \\
\text { 2016; Tung, Chang, } \\
\& \text { Chou, 2008) } \\
\text { The current research } \\
\text { defines Perceived } \\
\text { Revenue } \\
\text { Cannibalization as the } \\
\text { perception that } \\
\text { adopting the new } \\
\text { technology will result } \\
\text { in a reduction or loss } \\
\text { of an existing revenue } \\
\text { stream. }\end{array}$ & $\begin{array}{l}\text { Perceived Financial Cost } \\
\text { 'I would say the main the primary } \\
\text { inhibitor is the cost and infrastructure } \\
\text { related to blockchain related to most } \\
\text { applications... Ultimately, the cost related } \\
\text { to building these blockchain networks is } \\
\text { pretty high. So, the problem that creates } \\
\text { is with high cost creates, you have to } \\
\text { solve a big enough problem to merit that } \\
\text { cost investment'. } \\
\text { Perceived Revenue Cannibalization } \\
\text { 'Why would I invest in something if it's } \\
\text { going to disrupt an existing revenue } \\
\text { model or business that I have?'. }\end{array}$ & 40 & $\mathrm{~T}$ \\
\hline 3 & $\begin{array}{l}\text { Perceived } \\
\text { Functional } \\
\text { Benefits }\end{array}$ & $\begin{array}{l}\text { Perceptions that use } \\
\text { of the new technology } \\
\text { will increase one's } \\
\text { job performance by } \\
\text { making tasks more } \\
\text { efficient } \\
\text { (Rauschnabel, He, \& } \\
\text { Ro, 2018; Davis, } \\
\text { 1989). }\end{array}$ & $\begin{array}{l}\text { 'Efficiency is the number one. And I } \\
\text { think the enablement of some use cases } \\
\text { that just aren't possible in the world of } \\
\text { traditional technologies'. }\end{array}$ & 30 & $\mathrm{~T}$ \\
\hline
\end{tabular}




\begin{tabular}{|c|c|c|c|c|c|}
\hline No. & Name & Definition & Quote & No & $\begin{array}{l}\text { TOE } \\
\text { Context }\end{array}$ \\
\hline & & $\begin{array}{l}\text { The current research } \\
\text { extends this definition } \\
\text { to include perceptions } \\
\text { that the new } \\
\text { technology will } \\
\text { increase overall } \\
\text { organizational } \\
\text { efficiency. }\end{array}$ & & & \\
\hline 4 & $\begin{array}{l}\text { Perceived } \\
\text { Complexity }\end{array}$ & $\begin{array}{l}\text { The perceived degree } \\
\text { of difficulty related to } \\
\text { understanding or } \\
\text { making use of a new } \\
\text { technology (Alomari, } \\
\text { Woods, \& Sandhu, } \\
\text { 2012; Rogers, 1995). }\end{array}$ & $\begin{array}{l}\text { 'It's complex. This is something new, it's } \\
\text { foreign to people and behaves entirely } \\
\text { differently than traditional technologies } \\
\text { and their eyes glaze over with the } \\
\text { complexity associated with cryptography } \\
\text { and hashing and immutability, and all } \\
\text { those kinds of new concepts related to } \\
\text { blockchain'. }\end{array}$ & 24 & $\mathrm{~T}$ \\
\hline 5 & $\begin{array}{l}\text { Perceived } \\
\text { Information } \\
\text { Privacy Risk }\end{array}$ & $\begin{array}{l}\text { The perceived risk of } \\
\text { negative personal } \\
\text { information } \\
\text { disclosure resulting } \\
\text { from using a new } \\
\text { technology (Dong, } \\
\text { Chang, Wang, \& Yan, } \\
\text { 2017; Yin, Liu, \& } \\
\text { Lin, 2015). }\end{array}$ & $\begin{array}{l}\text { 'Privacy is another big reason why } \\
\text { people don't want to implement this or } \\
\text { why it's slow down...In certain business } \\
\text { situations people don't want to share all } \\
\text { data with each other and sometimes they } \\
\text { don't even want to share, they want to } \\
\text { share data with one party but not with } \\
\text { another one so privacy is a big issue'. }\end{array}$ & 18 & $\mathrm{~T}$ \\
\hline 6 & $\begin{array}{l}\text { Perceived } \\
\text { Technological } \\
\text { Volatility }\end{array}$ & $\begin{array}{l}\text { Perceptions of } \\
\text { uncertainty regarding } \\
\text { a technology's rate of } \\
\text { change in } \\
\text { specifications or } \\
\text { improvement's } \\
\text { (Mishra, Konana, \& } \\
\text { Barua, 2007). } \\
\text { The current research } \\
\text { extends this definition } \\
\text { to include perceptions } \\
\text { that the technology is } \\
\text { expected to } \\
\text { experience recurrent } \\
\text { changes or experience } \\
\text { rapid innovation. }\end{array}$ & $\begin{array}{l}\text { 'Another one would be until the tooling } \\
\text { and the actual underlying technologies } \\
\text { mentioned, get to another point of } \\
\text { refinement there's too much, forking } \\
\text { there's too much variation. So, there's the } \\
\text { risk of investing in one particular } \\
\text { direction of a blockchain. And then the } \\
\text { risk of that specific technology, end up } \\
\text { being end of life or outdated, and } \\
\text { replaced by something else'. }\end{array}$ & 18 & $\mathrm{~T}$ \\
\hline 7 & $\begin{array}{l}\text { Perceived } \\
\text { Scalability }\end{array}$ & $\begin{array}{l}\text { The perception of a } \\
\text { system's ability to } \\
\text { scale and cope with } \\
\text { an increased or } \\
\text { growing workload } \\
\text { (Weinstock \& } \\
\text { Goodenough 2006; } \\
\text { Tomás et al., 2018). } \\
\text { The present research } \\
\text { extends this definition } \\
\text { to include three }\end{array}$ & $\begin{array}{l}\text { 'Things like public permission less } \\
\text { blockchains just don't have the } \\
\text { throughput necessary to process financial } \\
\text { services transactions, seven transactions } \\
\text { a second, and an update of the of the } \\
\text { ledger every } 10 \text { minutes like in Bitcoin is } \\
\text { a non-starter in } 99.9 \% \text { of all use cases } \\
\text { inside a big bank like ours'. }\end{array}$ & 17 & $\mathrm{~T}$ \\
\hline
\end{tabular}




\begin{tabular}{|c|c|c|c|c|c|}
\hline No. & Name & Definition & Quote & No & $\begin{array}{l}\text { TOE } \\
\text { Context }\end{array}$ \\
\hline & & $\begin{array}{l}\text { scalability attributes } \\
\text { for blockchain } \\
\text { technology; the } \\
\text { volume of data, the } \\
\text { transaction rate } \\
\text { (throughput), and } \\
\text { latency (transaction } \\
\text { speed) (Koteska, } \\
\text { Karafiloski, \& } \\
\text { Mishev, 2017) }\end{array}$ & & & \\
\hline 8 & $\begin{array}{l}\text { Perceived } \\
\text { Interoperability }\end{array}$ & $\begin{array}{l}\text { Perceptions of the } \\
\text { ability for separate } \\
\text { technological } \\
\text { systems to } \\
\text { communicate } \\
\text { information with each } \\
\text { other, operate with } \\
\text { that information, and } \\
\text { otherwise cooperate } \\
\text { (Gordon \& Catalini, } \\
\text { 2018; Naudet, Latour, } \\
\text { Guedria, \& Chen, } \\
\text { 2010). }\end{array}$ & $\begin{array}{l}\text { 'The infrastructure of the organization's } \\
\text { kind of information technology and } \\
\text { information management environment } \\
\text { hasn't been built in such a way to kind of } \\
\text { readily integrate that type of solution into } \\
\text { the environment'. }\end{array}$ & 14 & $\mathrm{~T}$ \\
\hline 9 & $\begin{array}{l}\text { Perceived } \\
\text { Security Risk } \\
\text { Perceived } \\
\text { Identity } \\
\text { Management } \\
\text { Complexity - } \\
\text { Sub-Factor - A } \\
\text { specific } \\
\text { instance of a } \\
\text { perceived } \\
\text { security risk. }\end{array}$ & $\begin{array}{l}\text { Organizational } \\
\text { perceptions } \\
\text { surrounding the risk } \\
\text { of the new technology } \\
\text { with respect to safety } \\
\text { and security of the } \\
\text { organization's } \\
\text { information } \\
\text { technology (Raut, } \\
\text { Priyadarshinee, } \\
\text { Gardas, \& Jha, 2018). } \\
\text { This includes the } \\
\text { perception of loss due } \\
\text { to fraud or a } \\
\text { malicious actor } \\
\text { hacking the system } \\
\text { compromising its } \\
\text { security (Naicker \& } \\
\text { Van Der Merwe, } \\
\text { 2018). } \\
\text { The present research } \\
\text { defines Identity } \\
\text { Management } \\
\text { Complexity as the } \\
\text { perceived security } \\
\text { risk associated with } \\
\text { the difficulty of } \\
\text { managing digital }\end{array}$ & $\begin{array}{l}\text { Perceived Security Risk } \\
\text { 'The technology is irrelevant to humans } \\
\text { if it can't be used effectively and we are } \\
\text { not designed to remember } 256 \text { bits of } \\
\text { gibberish. So, we forget our keys, if you } \\
\text { forget your keys, your information is lost } \\
\text { forever but if I can remember your key } \\
\text { for you, well then, I can pretend to be } \\
\text { you. So, it is not obvious how to } \\
\text { remediate that problem'. } \\
\text { Identity Management Complexity - Sub- } \\
\text { Theme } \\
\text { 'The challenge is that to have a pure play } \\
\text { blockchain implementation like the kind } \\
\text { I envision with whereby every individual } \\
\text { will control their own identity through } \\
\text { their identity management software or } \\
\text { wallet, that's impractical today because } \\
\text { most people don't have identity } \\
\text { management tools that they use'. }\end{array}$ & 11 & $\mathrm{~T}$ \\
\hline
\end{tabular}




\begin{tabular}{|c|c|c|c|c|c|}
\hline No. & Name & Definition & Quote & No & $\begin{array}{l}\text { TOE } \\
\text { Context }\end{array}$ \\
\hline & & $\begin{array}{l}\text { identities for the new } \\
\text { technology. }\end{array}$ & & & \\
\hline 10 & $\begin{array}{l}\text { Perceived Lack } \\
\text { of } \\
\text { Technological } \\
\text { Knowledge }\end{array}$ & $\begin{array}{l}\text { The perceived } \\
\text { specialized } \\
\text { knowledge and skills } \\
\text { needed to use the } \\
\text { technology being } \\
\text { adopted (Lin \& Lin, } \\
\text { 2008; Lee \& Shim, } \\
\text { 2007; Thong, 1999). } \\
\text { The current research } \\
\text { extends this definition } \\
\text { to reflect a lack of } \\
\text { knowledge, therefore } \\
\text { defining Perceived } \\
\text { Lack of } \\
\text { Technological } \\
\text { Knowledge as } \\
\text { perceptions regarding } \\
\text { the lack of specialized } \\
\text { knowledge and skills } \\
\text { needed to use the } \\
\text { technology being } \\
\text { adopted. }\end{array}$ & $\begin{array}{l}\text { 'I would start with number one the most } \\
\text { important I think is a lack of } \\
\text { understanding of the technology across } \\
\text { the enterprise level and an executive } \\
\text { level. That it's not an understood } \\
\text { technology and its potential in terms of } \\
\text { how you can turn it into a practical tool } \\
\text { for the organization'. }\end{array}$ & 33 & $\mathrm{O}$ \\
\hline 11 & $\begin{array}{l}\text { Perceived Risk } \\
\text { Perceived } \\
\text { Tokenization } \\
\text { Risk - Sub- } \\
\text { Factor - A } \\
\text { specific } \\
\text { instance of a } \\
\text { perceived risk. }\end{array}$ & $\begin{array}{l}\text { The perceived } \\
\text { possible damages or } \\
\text { losses resulting from } \\
\text { a technological } \\
\text { investment (Raut et } \\
\text { al., 2018). } \\
\text { The present research } \\
\text { defines Perceived } \\
\text { Tokenization Risk as } \\
\text { perceptions of } \\
\text { enhanced risk } \\
\text { resulting from } \\
\text { operating with } \\
\text { tokenized assets or } \\
\text { cryptocurrencies. }\end{array}$ & $\begin{array}{l}\text { Perceived Risk } \\
\text { 'You always try to get multiple } \\
\text { perspectives to be able to cover off those } \\
\text { risks that you may not see. Anyone } \\
\text { within the industry that says a distributed } \\
\text { network inherently has no risks is on a } \\
\text { false premise, right? But there hasn't } \\
\text { been a lot of work to identify what are } \\
\text { the operational risks associated with } \\
\text { creating a distributed network. } \\
\text { Something as simple as upgradeability on } \\
\text { a block chain network? Who decides how } \\
\text { to upgrade? How much backward } \\
\text { compatibility do you consider as part of } \\
\text { that block chain network, because not all } \\
\text { your partners would be as sophisticated } \\
\text { as the lowest common denominator... we } \\
\text { always talk about malicious nodes from } \\
\text { the perspective of hacking but what if } \\
\text { there was a node who just refused to } \\
\text { upgrade and just kept the network within } \\
\text { stasis'. } \\
\text { Perceived Tokenization Risk } \\
\text { 'I see a lot of companies that have gone } \\
\text { down the tokenization road and I think } \\
\text { there's going to be a lot of corpses there, } \\
\text { that are going to cause the casual }\end{array}$ & 32 & $\mathrm{O}$ \\
\hline
\end{tabular}




\begin{tabular}{|c|c|c|c|c|c|}
\hline No. & Name & Definition & Quote & No & $\begin{array}{l}\text { TOE } \\
\text { Context }\end{array}$ \\
\hline & & & $\begin{array}{l}\text { observer of blockchain to be quite wary } \\
\text { of the technology'. }\end{array}$ & & \\
\hline 12 & $\begin{array}{l}\text { Shared } \\
\text { Governance }\end{array}$ & $\begin{array}{l}\text { The present research } \\
\text { defines Shared } \\
\text { Governance as the } \\
\text { difficulty of } \\
\text { establishing a shared } \\
\text { governance structure } \\
\text { for the operation and } \\
\text { management of a new } \\
\text { technology solution. }\end{array}$ & $\begin{array}{l}\text { 'I think another issue that we're seeing } \\
\text { which is impeding projects from going } \\
\text { further into production would be coming } \\
\text { up with proper governance frameworks } \\
\text { or governance models around the system. } \\
\text { So, if you're sharing a ledger between } \\
\text { different participants. How is the ledger } \\
\text { being managed today? How's it going to } \\
\text { be managed going forward. Is there an } \\
\text { owner or different people owning it, how } \\
\text { are decisions made so there's a lot of } \\
\text { factors that you need to get people } \\
\text { aligned on I guess before you enter into } \\
\text { some sort of consortium or agreement to } \\
\text { share certain processes on a ledger... It's } \\
\text { very difficult to get different business } \\
\text { leaders to sit down around a table and } \\
\text { agree on how data is going to be shared } \\
\text { and manage between them'. }\end{array}$ & 29 & $\mathrm{O}$ \\
\hline 13 & $\begin{array}{l}\text { Perceived } \\
\text { Regulatory } \\
\text { Uncertainty }\end{array}$ & $\begin{array}{l}\text { Perceived uncertainty } \\
\text { or a lack of clarity } \\
\text { regarding the legal } \\
\text { and regulatory status } \\
\text { for the use of a new } \\
\text { technology } \\
\text { (Abramova \& Böhme, } \\
\text { 2016). }\end{array}$ & $\begin{array}{l}\text { 'If there's ambiguity and uncertainty with } \\
\text { regards to taking on an initiative that may } \\
\text { require changes downstream based on } \\
\text { changes in legislation regulation, chances } \\
\text { are, the initiative will not get the right } \\
\text { business case to move forward. Right, } \\
\text { because there's no certainty there from a } \\
\text { business case perspective'. }\end{array}$ & 41 & $\mathrm{E}$ \\
\hline 14 & $\begin{array}{l}\text { Perceived } \\
\text { Standardization } \\
\text { Uncertainty }\end{array}$ & $\begin{array}{l}\text { Perceived } \\
\text { standardization is } \\
\text { defined as the } \\
\text { perceived existence } \\
\text { and degree of } \\
\text { consistency of } \\
\text { standards for the } \\
\text { technology within and } \\
\text { across industries } \\
\text { (Lacity, 2018; Jang, } \\
\text { 2010). } \\
\text { The current research } \\
\text { extends this definition } \\
\text { to incorporate } \\
\text { uncertainty: } \\
\text { perceived uncertainty } \\
\text { regarding the } \\
\text { existence and degree } \\
\text { of consistency of } \\
\text { standards for the } \\
\text { technology within and } \\
\text { across industries. }\end{array}$ & $\begin{array}{l}\text { 'I think definitely it will be would be } \\
\text { kind of, like, a hindrance on adoption of } \\
\text { blockchain technology, especially } \\
\text { because I think really, the potential lies in } \\
\text { the ability to kind of share information } \\
\text { across multiple different parties and if } \\
\text { there's no kind of standard around that, } \\
\text { then I'm not sure you can really, how } \\
\text { much you can realize that potential'. }\end{array}$ & 30 & $\mathrm{E}$ \\
\hline
\end{tabular}




\begin{tabular}{|l|l|l|l|l|l|}
\hline No. & Name & Definition & Quote & $\begin{array}{l}\text { NOE } \\
\text { Context }\end{array}$ \\
\hline 15 & $\begin{array}{l}\text { Perceived } \\
\text { Network } \\
\text { Enhancement }\end{array}$ & $\begin{array}{l}\text { The research at hand } \\
\text { defines Perceived } \\
\text { Network } \\
\text { Enhancement as } \\
\text { perceptions the } \\
\text { technology being } \\
\text { adopted can improve } \\
\text { the quality of } \\
\text { existing, internal or } \\
\text { external, networks or } \\
\text { can create new } \\
\text { networks. }\end{array}$ & $\begin{array}{l}\text { One of the areas we feel that there's a } \\
\text { cross jurisdictional governance between } \\
\text { the provincial municipal and federal } \\
\text { levels...to streamline that business } \\
\text { process and those integration points in } \\
\text { those relationships. So, I think we see } \\
\text { blockchain and being a very viable, } \\
\text { logical technology that's going to be part } \\
\text { of the continued evolution of building } \\
\text { those digital integrations with external } \\
\text { agencies or organizations of the city } \\
\text { where we do business with them'. }\end{array}$ & 17 \\
\hline
\end{tabular}

Table 3 - Organization-Level Blockchain Adoption Factors

As a reliability and validity check for the content analysis, an intra-rater reliability assessment was conducted. To do so, $25 \%$ of the transcripts were randomly chosen and re-coded using a second user account. The results of the original coding and the re-coding were very similar. As such, the results are determined to be robust.

\subsection{Study 2 - Quantitative Method - Survey}

The following section provides a detailed description of the quantitative methodology used for Study 2. It begins with hypothesis development, which is followed by scale development, data collection, and data analysis. Regarding the constructs identified in Study 1, seven constructs had robust scales, passed the pilot study (discussed in section 2.2.3), and had high novelty for the blockchain technology adoption literature. These constructs were perceived data quality, perceived technological volatility, perceived interoperability, perceived lack of technological knowledge, perceived regulatory uncertainty, perceived standardization uncertainty, and perceived network enhancement. The constructs removed due to the pilot study, scale development and/or insufficient novelty are perceived financial cost, perceived revenue cannibalization, perceived information privacy risk, perceived functional benefit, perceived complexity, perceived scalability, perceived security risk, perceived identity management complexity, perceived risk, tokenization risk, and shared governance.

Three related control variables were considered for the cross-sectional variations for blockchain technology adoption. First, as the importance of collecting and analyzing data may vary by industry, the organization's industry was included as a control. Second, variability may 
exist in the results due to the organization's size, as larger firms often have access to more resources (Chen et al., 2014). As such, organization size was included as a control and was operationalized as the number of firm employees. Third, firm performance was included as a control due to the possibility of the respondents' subjective interpretation of the impact of data on the firm (Tomás et al., 2018). The preliminary model is depicted in Figure 2. 


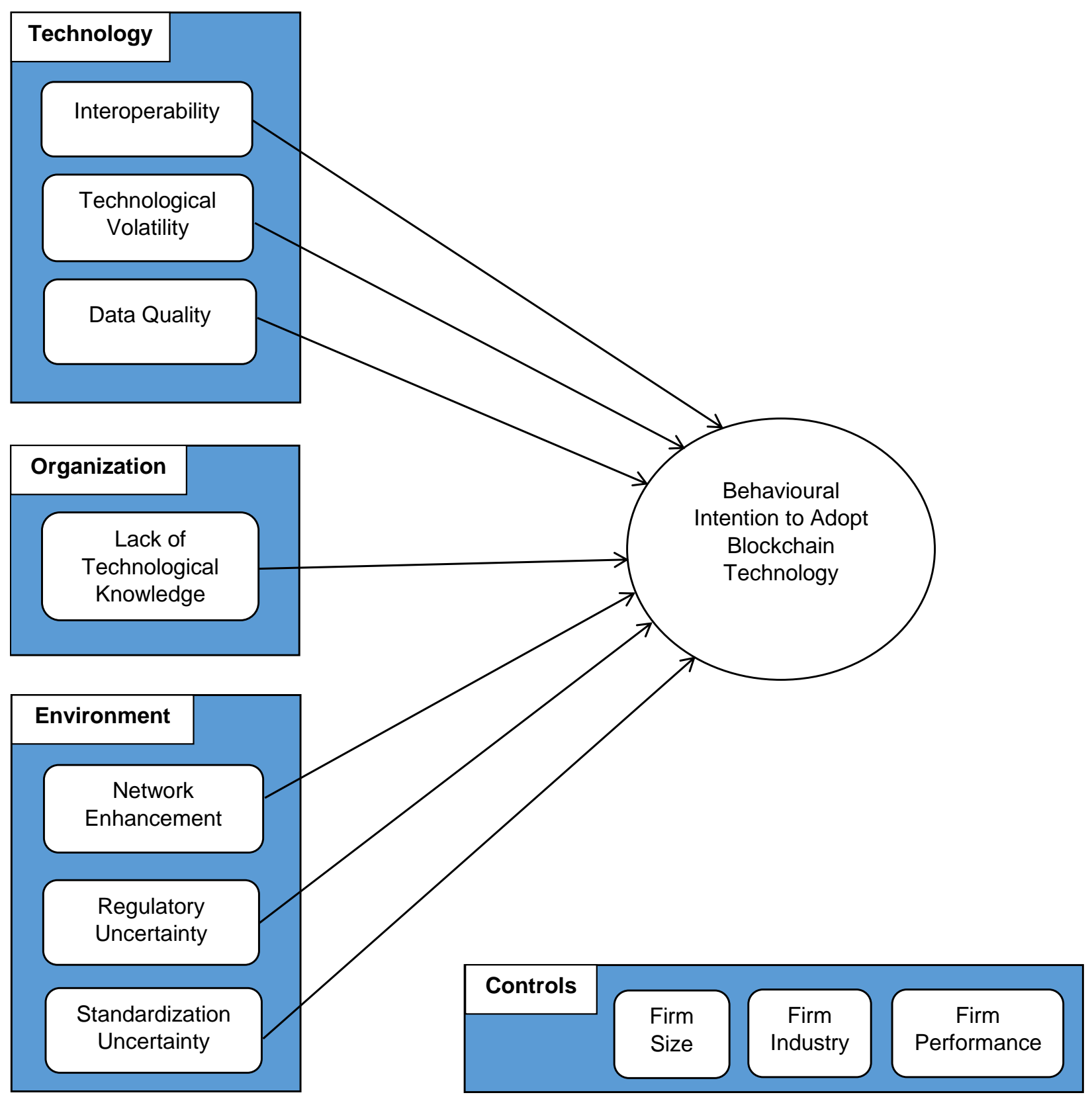

Figure 2 - Preliminary Model 


\subsubsection{Hypothesis Development}

The following section presents the theoretical rational and proposed hypotheses for each of the seven constructs from Study 1.

\subsubsection{Perceived Data Quality}

Perceived data quality was the most frequently mentioned adoption factor, across all TOE contexts, among the interviewees. Perceived data quality refers to the perceived attractive characteristics of the information systems output, such as quality, accuracy, completeness, availability and timeliness (Cheng, 2014; DeLone \& McLean, 1992; Daradkeh, 2018) and has been considered an important antecedent of technology adoption (Hsieh \& Lin, 2018; Demoulin \& Coussement, 2018; Aparicio, Oliveira, Bacao \& Painho, 2019). Aparicio et al., 2019 and Hsieh \& Lin (2018) hypothesized a direct positive relationship between data/information quality and their dependent variables; use and intention to use, respectively. The latter found a significant positive relationship while the former did not. Demoulin \& Coussement (2018) broke down their data/information quality construct into six sub-factors and hypothesized indirect positive relationships of the six sub factors on usage intention. All were found to be significant. In addition to previous research analyzing perceived data quality (or highly related factors such as information quality) for technology other than blockchain, Study 1 of this research and one other blockchain study (Altaei et al., 2019) have, based on interview data, identified data quality as an influential factor. Furthermore, Hoxha \& Sadiku (2019) studied the adoption of blockchain technology with several constructs similar to data quality and found that transparency, composed of data availability, reduction of information asymmetry, and easy verification of transactions, was a significant explanatory factor for adoption. It is blockchain technology's ability to provide tamperevident data, reduce single-points-of-failure, achieve a single version of the truth and enhance auditability that increases the quality, accuracy, completeness, availability and usability of an organization's data (Narayanan et al., 2016; Makhdoom et al., 2019; Wang et al., 2019b). To verify the positive relationships analyzed in prior research and to verify the relationship identified in this research, it is hypothesized that the higher the perceptions of data quality, the higher the behavioural intention to adopt blockchain technology. Formally:

H1 - Perceived data quality is positively associated with organizational blockchain technology adoption. 


\subsubsection{Perceived Technological Volatility}

Perceived technological volatility is characterized as perceptions of uncertainty regarding a technology's rate of change in specifications or improvements (Mishra et al., 2007). The current research extends this definition to include perceptions that the technology is expected to experience recurrent changes or experience rapid innovation. Although blockchain has been around since 2008 (Nakamoto, 2008), it is still relatively immature (Moezkarimi et al., 2019). It is still being rapidly developed, improved, and changed to incorporate new features. A standardized implementation methodology has not been developed to guide organizations with their new blockchain ventures. Novel blockchain solutions are created frequently and others are discontinued creating a diverse and ever changing set of platforms (Moezkarimi et al., 2019). Even the most stable blockchain implementations need to make changes, update their standards, modify their rules and/or implement new protocols. These changes can result in a hard or soft fork (Narayanan et al., 2016) and other operational changes in the network, which could have negative security and development implications. Frequent changes, developments and updates create technological volatility. Another word used in place of technological volatility is technical turbulence. Volatility or turbulence can create a sense of uncertainty, is disruptive to operations, and creates unstable environments (Martin, Javalgi, \& Ciravegna, 2020). Uncertainty in the mind of potential organizational adopters may therefore hinder adoption. Those interviewed in Study 1 of this research were concerned that an investment in one direction (being either an existing blockchain platform or a specific development direction) may result in unnecessary risk if the technological direction ends up being end of life, outdated, and/or replaced by something else. Organizations prefer to avoid unnecessary risk, wasted resources, and re-work and therefore avoid technological volatility. Accordingly, this research hypothesizes that the higher the perceptions of technological volatility, the lower the behavioural intention to adopt blockchain technology. Formally:

H2 - Perceived technological volatility is negatively associated with organizational blockchain technology adoption.

\subsubsection{Perceived Interoperability}

Perceived interoperability refers to perceptions of the ability for separate technological systems to communicate information with each other, operate with that information, and otherwise cooperate (Gordon \& Catalini, 2018; Naudet et al., 2010). The adoption of blockchain technology, 
depending on the organization, stipulates the choice and deployment of interphases and standards to ensure interoperability with the existing technological infrastructure. This may be a complex undertaking, however the more interoperable an organization perceives its current technological infrastructure to be, the more capable they will believe themselves to be to introduce new technology. Ranganathan, Teo, \& Dhaliwal (2011) found that interoperability had a direct positive relationship with the extent of web-enabled supply chain management systems use. In addition, Chau \& Tam (1997) found a positive relationship between perceived importance of interoperability and the adoption of open systems, highlighting the significance of this construct for organizational adoption of technology. In line with prior research, this research hypothesizes that the higher the perceptions of interoperability, the higher the behavioural intention to adopt blockchain technology. Formally:

H3 - Perceived interoperability is positively associated with organizational adoption of blockchain technology.

\subsubsection{Perceived Lack of Technological Knowledge}

Perceived technological knowledge can be defined as the perceived specialized knowledge and skills needed to use the technology being adopted (Lin \& Lin, 2008; Lee \& Shim, 2007; Thong, 1999). The current research extends this definition to reflect a lack of knowledge, therefore defining perceived lack of technological knowledge as perceptions regarding the lack of specialized knowledge and skills needed to use the technology being adopted. Thong (1999) studied the adoption of information systems (IS) for small businesses and noted obstacles exist when attempting to develop the skills and knowledge necessary to adopt IS, which can cause organizations to postpone their adoption until enough expertise is gained. Thong (1999) theorized that if an organization already has the necessary knowledge and skills, they will be more willing to adopt and if they are lacking the knowledge and skills, they were less likely. Thong (1999) hypothesized a positive relationship between employee IS knowledge and likelihood of adoption, however, the focus was the presence of knowledge, not the lack of knowledge. The research at hand is analyzing the lack of knowledge in relation to blockchain adoption, and therefore is hypothesizing a different relationship. Kuan \& Chau (2001) found that that electronic data interchange (EDI) adopter firms had a better (higher) perception of their internal technical competence and non-adopter firms perceived themselves to have a lack of technological 
competence (Kuan \& Chau, 2001). This is indicative of a negative relationship (the higher the lack of knowledge, the lower the intention to adopt) between a lack of technological knowledge and intention to adopt. In addition, some studies investigating blockchain adoption, including Study 1 from this research, has identified a lack of blockchain skills or expertise as hindering adoption (Altaei et al., 2019; Li et al., 2019b). To fully realize the benefits of blockchain technology and avoid costly mistakes, a full understanding of the technology is a prerequisite to adoption. To gain a full understanding of blockchain technology, a certain level of technological knowledge is required. With these arguments in mind this research hypothesizes that the higher the perceptions of a lack of technological knowledge, the lower the behavioural intention to adoption blockchain technology. Formally:

H4 - Perceived lack of technological knowledge is negatively associated with organizational adoption of blockchain technology.

\subsubsection{Perceived Regulatory Uncertainty}

Perceived regulatory uncertainty was found to be the most influential factor within the environmental context from our interviewees. Perceived regulatory uncertainty is characterized as a perceived lack of clarity regarding the legal and regulatory status for the use of a new technology (Abramova \& Böhme, 2016). A review of the technological adoption literature has revealed several studies that have considered the regulatory environment, but in much different ways than is needed for blockchain technology. For example, Zhu \& Kraemer (2005), Xu et al., (2004), and Zhu, Kraemer, \& Xu (2006) all used a regulation construct in their studies (regulatory support, and regulatory environment and regulatory environment, respectively), but they were described as the support the regulatory environment can give for the adoption or use of a technology. This would assume that a robust regulatory framework is already in place or that there is clear information as to the direction of the developing regulatory framework. With blockchain technology, it would seem that this is not the case. When Wong et al. (2019) hypothesized that regulatory support would positively influence behavioural intention to adopt blockchain technology; the findings were insignificant. Wong et al. (2019) concluded blockchain technology is in its infancy and regulations that would support adoption have not been developed. This is further supported by additional blockchain research (Lacity, 2018; Altaei, et al., 2018). Organizations are uncertain if future regulations will result in the termination of their blockchain 
solution. For example, the General Data Protection Regulations (GDPR), and the right to be forgotten (European Commission, n.d; Bhaimia, 2018), considers the hash of personally identifiable information (PII) to be PII. If the hash of PII is considered PII and an organization is using a blockchain solution, they may be forced to abolish the blockchain, depending on the implementation, if similar privacy focused regulations extend to their native country. This is because the data contained within a blockchain is append-only, meaning once data has been input to a blockchain it cannot be easily erased (Yaga et al., 2018). Accordingly, this research hypothesizes that the higher the perceptions of regulatory uncertainty, the lower the behavioural intention to adopt blockchain technology. Formally:

H5 - Perceived regulatory uncertainty is negatively associated with organizational adoption of blockchain technology.

\subsubsection{Perceived Standardization Uncertainty}

Perceived standardization refers to perceptions of the existence and degree of consistency of standards, for the technology being adopted, within and across industries (Lacity, 2018; Jang, 2010). The current research extends this definition to incorporate uncertainty and, therefore, defines perceived standardization uncertainty as perceptions of uncertainty regarding the existence and degree of consistency of standards for the technology within and across industries. Similar to perceived regulatory uncertainty, an examination of the technological adoption literature has revealed research that have considered technological standardization (Jang, 2010; Norton, Rodriguez, Shortell, \& Lewis, 2019) but in a different way than is needed for blockchain technology. For example, Norton et al. (2019) found that the hospitals with more standardized electronic health records, were more likely to adopt new health care information technology; showing that the presence of standards positively influences adoption. However, with blockchain technology standards have not been developed (Lacity, 2018; Van Hoek, 2019). In fact, Yang (2019) empirically validated that a blockchain future improvement incorporating standardization and platform development is positively associated with intention to use, showing a current lack of standards and that developing them will push adoption. A consequence of no standards is uncertainty, which can result in organizations taking it upon themselves to develop and use their own standards. If a multitude of organizations are developing their own standards, the result is fragmentation. This can make proper coordination and interoperability difficult for future 
endeavours. Many blockchain solutions rely on the coordination of several organizational actors within an industry and if they are all following different standards, proper integration will be difficult. This presents an inherent risk that developing a blockchain solution now and without clarity regarding standards may dictate significant re-work to ensure compliance. Aligned with the presented theorizing, this research hypothesizes that the higher the perceptions of standardization uncertainty, the lower the behavioural intention to adopt blockchain technology. Formally:

H6 - Perceived standardization uncertainty is negatively associated with organizational adoption of blockchain technology.

\subsubsection{Perceived Network Enhancement}

The research at hand defines perceived network enhancement as perceptions that the technology being adopted can improve the quality of existing, internal or external, networks or can create new networks. Blockchain technology has several properties with the ability to enhance networks. Blockchains are tamper-evident data structures, which improve data integrity (Narayanan et al., 2016; Hughes et al., 2019) which, in turn, enhances the quality of data within business networks and thus, the network itself. Blockchains can also provide enhanced transparency (Narayanan et al., 2016; Hughes et al., 2019), which can facilitate increased trust within a network, which improves the network. Finally, every organization within a network, operating with blockchain as their data backbone, shares a single data repository (the chain) and interface, making blockchain technology the logical glue connecting the network. Organizations are aware of the network enhancing properties of blockchain technology and, as a result, perceived network enhancement was a predominant factor mentioned by our interviewees. Being that blockchain technology is capable of enhancing networks and that organizations perceive this ability to be true, this research hypothesizes that the higher the perceptions of network enhancement, the higher the intention to adopt blockchain technology. Formally:

H7 - Perceived network enhancement is positively associated with organizational adoption of blockchain technology.

\subsubsection{Scale Development/Design}

In this research, previously validated instruments were used for all scale items (See Table 4 for information regarding the scales including where they were adopted/adapted from) except for 
perceived technological volatility, as validated scale items were not located. Existing scale items were either adopted, adapted or inspired from. Following Moore \& Benbasat's (1991) process, perceived technological volatility was developed as a reflective construct to be congruent with the other reflective constructs in the model.

\subsubsection{Data Collection}

A pilot study was conducted with 14 blockchain subject matter experts who had no role in Study 1. The participants were all employees of a blockchain start up company focused on developing blockchain solutions in North America. They were all knowledgeable about and experienced with the adoption/development of blockchain applications and therefore suitable for the pilot test. After amending the instrument based on feedback from the pilot study, a list of 71 organizations ranging from start-ups to large organizations across a multitude of industry classifications (e.g., financial, health care, public services) in North America were identified for survey distribution. Convenience sampling was employed to identify the organizations.

Each organization was contacted to ensure they were considering adopting blockchain technology. After verifying they were potential users or were experts with blockchain technology (such as blockchain service providers or consultants), they were invited to participate in our research and a link to the survey was sent to them by email. To do so, e-mails were sent asking employees to complete the survey and included a link to the questionnaire for online completion. The survey remained open from the beginning of April to the end of August 2019. In total, 570 employees received the survey, 194 completed it and 146 responses were reliable to be used for analysis. A snowballing sampling method was used to obtain employee responses. Specifically, the individuals from the sample in Study 1 were asked to complete the survey themselves and to have several of their employees, knowledgeable about blockchain technology, to also complete it. Appendix B outlines the demographics of the sample used in Study 2 and Appendix E provides the survey instrument.

To determine whether non-response bias was present, this research followed Armstrong \& Overton's (1977) guidelines. The demographic and main variable responses (adoption factors) of early and late participants were compared. The findings indicated no significant differences between the early and late respondents. Hence, non-response bias did not affect this research. 


\subsubsection{Data Analysis and Results}

Study 2 used PLS-SEM for analysis, specifically SmartPLS version 3.2.8. The rational for this selection is that PLS-SEM is made to maximize the total variance explained (R2) by the latent variables, making its core goal to predict target constructs (Hair, Ringle, \& Sarstedt, 2011). This is congruent with the objective of this research: predicting the factors influencing the adoption of blockchain technology and systematizing them into a theoretical framework. PLS-SEM is dissimilar to the covariance SEM techniques, which surround both exploration and theory testing and confirmation, further supporting this selection.

In terms of reporting and conducting PLS-SEM, the research at hand mirrored the standard evaluation guidelines indicated by Hair, Hult, Ringle, Sarstedt \& Thiele (2017) and Hair et al. (2017b). As recommended, the analysis was performed in two stages: first, the measurement model and second, the structural model.

Additionally, when using self-reported data, the possibility for common method bias arises. Common method bias can be described as variance that is imputable to a measurement method as opposed to the factors the measures signify. To test for common method bias, Harman's one factor test was used as recommended by Podsakoff, MacKenzie Lee, \& Podsakoff, (2003). The results indicate multiple factors and that these factors, combined, explain $<50 \%$ of the total variance. This verifies that no considerable common methods bias exists (Suh, Kim, \& Suh, 2011). Therefore, common method bias is not a concern for this research.

\subsubsection{Measurement Model}

The initial model included organization size, firm performance, and industry classification as control variables. When organization size and industry classification are removed, the effect on the variance described in the outcome variable ( $\mathrm{t}$-values ranged from 0.2 to 1.4) was marginal, if any. Therefore organization size and industry were removed from the model. The measurement model was tested to confirm the constructs had adequate reliability and validity. Reliability was measured by means of internal consistency scores determined by the construct's composite reliability score (CR) and Cronbach's alpha (a). Internal consistency scores are acceptable if they surpass the 0.70 threshold (Hair et al., 2017b). Factor loadings were also assessed and must surpass 0.50. Validity was assessed based on the convergent and discriminant validity, measured as the average variance extracted (AVE) and Heterotrait-Monotrait Ratio (HTMT) (Henseler, Ringle, \& 
Sarstedt, 2015; Hair, Sarstedt, \& Ringle, 2019), respectively. The AVE is acceptable if it is greater than 0.50 and the HTMT ratios are acceptable if they fall below 0.90. Some construct statements with lower factor loadings were removed, resulting in an improved model. The full construct scale items can be found in the survey instrument in Appendix E. Table 4 shows the measurement model results. The HTMT ratios are also shown below in Table 5.

\begin{tabular}{|c|c|c|c|c|}
\hline \multicolumn{5}{|l|}{ Instrument Items } \\
\hline $\begin{array}{l}\text { Behavioral Intention to Adopt Blockchain Technology (BI) - } \\
\text { Adopted from Venkatesh et al. (2003) }\end{array}$ & Loadings & $a$ & CR & AVE \\
\hline \multirow{3}{*}{$\begin{array}{l}\text { BI1: Our organization will use blockchain technology on a regular } \\
\text { basis in the future. } \\
\text { BI2: Our organization will use blockchain technology or a similar type } \\
\text { of system for requests (transactions or other processing requirements). } \\
\text { BI3: Our organization plans to use blockchain technology in the next } \\
\text { year. }\end{array}$} & 0.962 & \multirow{3}{*}{0.949} & \multirow{3}{*}{0.967} & \multirow{3}{*}{0.907} \\
\hline & 0.978 & & & \\
\hline & 0.916 & & & \\
\hline $\begin{array}{l}\text { Regulatory Uncertainty (PRU) - Inspired from Abramova \& } \\
\text { Böhme, } 2016 \text { and Wong et al. (2019) }\end{array}$ & Loadings & $a$ & CR & AVE \\
\hline \multirow{3}{*}{$\begin{array}{l}\text { PRU1: Our organization is concerned that blockchain technology will } \\
\text { result in compliance deficiencies. } \\
\text { PRU2: Our organization is concerned that blockchain technology will } \\
\text { result in legal fines. } \\
\text { PRU3: Blockchain technology will bring new regulations forcing new } \\
\text { compliance considerations. }\end{array}$} & 0.940 & \multirow{3}{*}{0.838} & \multirow{3}{*}{0.900} & \multirow{3}{*}{0.752} \\
\hline & 0.934 & & & \\
\hline & 0.708 & & & \\
\hline $\begin{array}{l}\text { Perceived Data Quality (PDQ)-Adapted from DeLone \& McLean } \\
\text { (1992) and Aparicio et al. (2019) }\end{array}$ & Loadings & $a$ & $\mathbf{C R}$ & AVE \\
\hline \multirow{5}{*}{$\begin{array}{l}\text { PDQ1: Our organization will benefit from blockchain technology's } \\
\text { ability to reduce the risk of a single point of failure. } \\
\text { PDQ2: Our organization will benefit from blockchain technology's } \\
\text { tamper evident data structure. } \\
\text { PDQ3: Our organization will benefit from blockchain technology's } \\
\text { ability to provide a single version of the truth. } \\
\text { PDQ4: Blockchain technology will increase the efficiency of our } \\
\text { organization's ability to perform data reconciliation. } \\
\text { PDQ5: Blockchain technology will increase our organization's data } \\
\text { auditability. }\end{array}$} & 0.894 & \multirow{5}{*}{0.949} & \multirow{5}{*}{0.961} & \multirow{5}{*}{0.830} \\
\hline & 0.941 & & & \\
\hline & 0.927 & & & \\
\hline & 0.888 & & & \\
\hline & 0.904 & & & \\
\hline Firm Performance (FP) - Adopted from Rhee, Park, \& Lee (2010) & Loadings & $a$ & CR & AVE \\
\hline \multirow{3}{*}{$\begin{array}{l}\text { FP1: In comparison with your major competitors over the past two } \\
\text { years, your organization has a faster growth rate. } \\
\text { FP2: In comparison with your major competitors over the past two } \\
\text { year, your organization has higher profitability. } \\
\text { FP3: In comparison with your major competitors over the past two } \\
\text { years, your organization has become more efficient. }\end{array}$} & 0.866 & \multirow{3}{*}{0.793} & \multirow{3}{*}{0.875} & \multirow{3}{*}{0.701} \\
\hline & 0.781 & & & \\
\hline & 0.863 & & & \\
\hline $\begin{array}{l}\text { Perceived Interoperability (PI) - Adapted from Ranganathan et al. } \\
\text { (2011) }\end{array}$ & Loadings & $a$ & CR & AVE \\
\hline \multirow{3}{*}{$\begin{array}{l}\text { PI1: If we adopted blockchain technology, it would be compatible with } \\
\text { our legacy systems. } \\
\text { PI2: If we adopted blockchain technology, it would be compatible with } \\
\text { our legacy processes. } \\
\text { PI3: If we adopted blockchain technology, it would be compatible with } \\
\text { our legacy databases. }\end{array}$} & 0.883 & \multirow{3}{*}{0.797} & \multirow{3}{*}{0.881} & \multirow{3}{*}{0.711} \\
\hline & 0.810 & & & \\
\hline & 0.836 & & & \\
\hline
\end{tabular}




\begin{tabular}{|c|c|c|c|c|}
\hline $\begin{array}{l}\text { Perceived Lack of Technological Knowledge (PLTK)- Adapted from } \\
\text { Lee \& Shim (2007) }\end{array}$ & Loadings & $a$ & $\mathbf{C R}$ & AVE \\
\hline PLTK1: Our organization has little knowledge about how blockchain & 0.900 & \multirow{3}{*}{0.882} & \multirow{3}{*}{0.927} & \multirow{3}{*}{0.809} \\
\hline & 0.905 & & & \\
\hline $\begin{array}{l}\text { PLTK3: Our organization's technology decision makers do not fully } \\
\text { understand blockchain technology. }\end{array}$ & 0.894 & & & \\
\hline $\begin{array}{l}\text { Perceived Network Enhancement (PNE) - Adapted from Forsman } \\
\text { (2011) }\end{array}$ & Loadings & $a$ & $\mathbf{C R}$ & AVE \\
\hline $\begin{array}{l}\text { PNE1: Blockchain technology can provide networking opportunities } \\
\text { for our organization. }\end{array}$ & 0.844 & \multirow{4}{*}{0.899} & \multirow{4}{*}{0.929} & \multirow{4}{*}{0.767} \\
\hline $\begin{array}{l}\text { PNE2: Blockchain technology can create collaborative relationships } \\
\text { for our organization. }\end{array}$ & 0.930 & & & \\
\hline $\begin{array}{l}\text { PNE3: Blockchain technology can exploit new networks in our } \\
\text { business environment. }\end{array}$ & 0.857 & & & \\
\hline $\begin{array}{l}\text { PNE4: Blockchain technology can strengthen our organization's } \\
\text { existing networks. }\end{array}$ & 0.870 & & & \\
\hline Perceived Technological Volatility (PTV) - Developed scale & Loadings & $a$ & CR & AVE \\
\hline \multirow{3}{*}{$\begin{array}{l}\text { PTV1: Our organization finds it difficult to make meaningful } \\
\text { comparisons between different blockchains. } \\
\text { PTV2: Well-established blockchains cannot be trusted to remain stable. } \\
\text { PTV3: Blockchain technology is too immature for our organization. }\end{array}$} & 0.724 & \multirow{3}{*}{0.707} & \multirow{3}{*}{0.836} & \multirow{3}{*}{0.630} \\
\hline & 0797 & & & \\
\hline & 0.855 & & & \\
\hline $\begin{array}{l}\text { Perceived Standardization Uncertainty (PSU) - Inspired from Yang } \\
(2019\end{array}$ & Loadings & $a$ & CR & AVE \\
\hline \multirow{4}{*}{$\begin{array}{l}\text { PSU1: Our organization is concerned blockchain technology standards } \\
\text { are inconsistent across blockchain platforms. } \\
\text { PSU2: Our organization is concerned blockchain technology standards } \\
\text { are not stable. } \\
\text { PSU3: Our organization is concerned our existing (internal) standards } \\
\text { are not compatible with external blockchain standards. } \\
\text { PSU4: Our organization is concerned blockchain technology has } \\
\text { poorly established standards. }\end{array}$} & 0.784 & \multirow{4}{*}{0.873} & \multirow{4}{*}{0.911} & \multirow{4}{*}{0.720} \\
\hline & 0.854 & & & \\
\hline & 0.874 & & & \\
\hline & 0.880 & & & \\
\hline
\end{tabular}

Table 4 - Measurement Model - Note: AVE=Average Variance Extracted; $\alpha=$ Cronbach's alpha; $\mathrm{CR}=$ Composite Reliability. All measures used seven point scales where higher values indicate greater agreement or higher evaluation.

Reviewing Table 4 shows that all constructs have good internal consistency. In addition, as outlined in Table 5, all HTMT values fell below the threshold of 0.90. The AVG for all constructs surpassed the correlations between any given construct and all other constructs. When contrasting inter-construct correlations with the AVE, all constructs share a higher variance with their own indicators than to the indicators of other constructs.

\begin{tabular}{|l|l|l|l|l|l|l|l|l|l|}
\hline & BI & FP & PRU & DQ & PI & PLTK & PNE & PSU & PTV \\
\hline BI & & & & & & & & & \\
\hline FP & 0.547 & & & & & & & & \\
\hline PRU & 0.392 & 0.119 & & & & & & & \\
\hline DQ & 0.569 & 0.682 & 0.305 & & & & & & \\
\hline
\end{tabular}




\begin{tabular}{|l|l|l|l|l|l|l|l|l|l|}
\hline PLTK & 0.68 & 0.294 & 0.537 & 0.37 & 0.332 & & & & \\
\hline PNE & 0.422 & 0.553 & 0.238 & 0.833 & 0.213 & 0.226 & & & \\
\hline PSU & 0.378 & 0.147 & 0.634 & 0.158 & 0.161 & 0.415 & 0.112 & & \\
\hline PTV & 0.692 & 0.239 & 0.628 & 0.4 & 0.205 & 0.674 & 0.346 & 0.694 & \\
\hline & BI & FP & PRU & DQ & PI & PLTK & PNE & PSU & PTV \\
\hline
\end{tabular}

Table 5 - Heterotrait - Monotrait Ratio

Further, the standardized root mean square residual (SRMR) did not indicate any concerns regarding the model fit as it is near .08 (SRMR =0.085) (Hu \& Bentler, 1999). In addition, when latent variables with high levels of internal consistency are in the model, more attention should be given to the model's predictive relevance to be aligned with the casual-predictive goal of SEMPLS. Therefore, the relevance of prognoses (Q2) should be considered. To do so, the Stone-Geisser criteria with a blindfolding procedure with an omission distance of 7 was used (Tenenhaus \& Hanafi, 2010). The results verify that the Q2 value (.562) is greater than zero indicating the model has high predictive validity (Hair et al., 2017a; Henseler et al., 2015).

\subsubsection{Structural Model}

Once the measurement model has been assessed, the structural model is analyzed to test the hypotheses. The PLS bootstrap resampling procedure, using an iteration of 1000 sub-samples selected with replacement from the original sample, was used to ensure the stability of the model and generate the percentile bootstrap P values. The R2 measure and the level of path coefficient significance were used to evaluate the structural model. The results of the analysis are shown in Figure 3. The results of the hypothesis testing are summarized in Table 6.

\begin{tabular}{|l|l|l|l|l|}
\hline Hypothesis & $\beta$ & P-value & t-values & Results \\
\hline H1: Regulatory Uncertainty $\rightarrow$ Blockchain Adoption & 0.046 & 0.548 & 0.601 & Not Supported \\
\hline H2: Data Quality $\rightarrow$ Blockchain Adoption & 0.232 & 0.016 & 2.421 & Supported \\
\hline $\begin{array}{l}\text { H3: Lack of Technological Knowledge } \rightarrow \text { Blockchain } \\
\text { Adoption }\end{array}$ & -0.302 & 0.000 & 4.365 & Supported \\
\hline H4: Interoperability $\rightarrow$ Blockchain Adoption & 0.216 & 0.000 & 3.643 & Supported \\
\hline H5: Network Enhancement $\rightarrow$ Blockchain Adoption & -0.033 & 0.748 & 0.321 & Not Supported \\
\hline H6: Technological Volatility $\rightarrow$ Blockchain Adoption & -0.281 & 0.000 & 4.180 & Supported \\
\hline $\begin{array}{l}\text { H7: Standardization Uncertainty } \rightarrow \text { Blockchain } \\
\text { Adoption }\end{array}$ & -0.036 & 0.653 & 0.449 & Not Supported \\
\hline
\end{tabular}

Table 6 - Hypothesis Results 


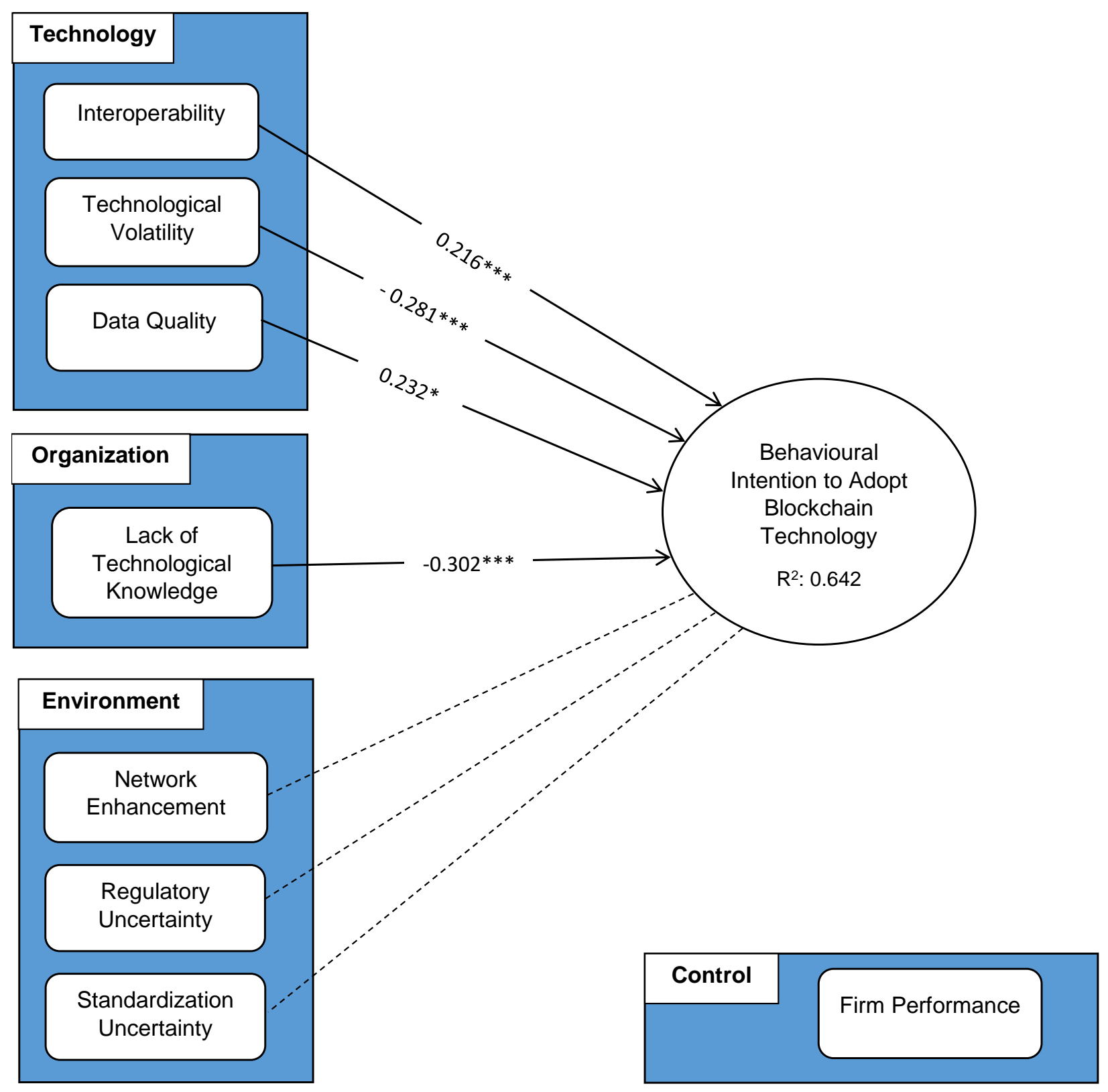

Note: ${ }^{*} p<.05,{ }^{* *} p<.01,{ }^{* * *} p<.001$

Figure 3 - PLS Structural Model with Path Coefficients 


\subsubsection{Quantitative Results}

The results show that perceived data quality and perceived interoperability had a significant positive relationship to blockchain adoption $(\beta=0.232, \mathrm{t}=2.432, \mathrm{p}<0.016 ; \beta=0.216, \mathrm{t}=3.643$, $\mathrm{p}<0.000)$. Moreover, the results indicate that perceived technological volatility and perceived lack of technological knowledge had a significant negative relationship to blockchain adoption ( $\beta$ $=-0.281, \mathrm{t}=4.180, \mathrm{p}<0.000 ; \beta=-0.302, \mathrm{t}=4.365, \mathrm{p}<0.000)$. Further, the control variable's (firm performance) relationship to blockchain adoption was significant $(\beta=0.184, \mathrm{t}=2.967, \mathrm{p}<$ 0.003). Perceived regulatory uncertainty, perceived standardization uncertainty, and perceived network enhancement were all found to be non-significant factors for blockchain technology adoption $(\beta=0.046, \mathrm{t}=0.601, \mathrm{p}<0.548 ; \beta=-0.036, \mathrm{t}=0.449, \mathrm{p}<0.653 ; \beta=-0.033, \mathrm{t}=0.321, \mathrm{p}$ $<0.748)$. Overall, referring to the effect size of significant relationships, perceived lack of technological knowledge had the largest effect, followed by perceived technological volatility and perceived interoperability $\left(\mathrm{f}^{2}=0.156 ; \mathrm{f}^{2}=0.116, \mathrm{f}^{2}=0.114\right.$ respectively) indicating an effect size falling in the range of small (0.15) (Cohen, 2013). 
Chapter 3 - Discussion 
The discussion of the results begins with a discussion of the blockchain adoption factors empirically tested in Study 2. Then, it presents managerial insights for blockchain technology development.

\subsection{General Discussion}

This research demonstrates blockchain technology adoption is primarily influenced by factors within the technological and organizational contexts, which can be used as a foundation for furthering blockchain adoption at the organizational level. The technological context is the most influential with three of the four significant adoption factors. Perceived data quality, interoperability and technological volatility were all found to have a significant influence on adoption; two positive relationships and one negative, respectively. Having most of the significant factors from the technological context suggests organizations are primarily focused on aspects of the technology for blockchain adoption and to a lesser extent, are considering their organizational or environmental context. The emphasis is on technological factors such as how blockchain can enhance data quality, whether it will integrate with the existing technological infrastructure, and how it is evolving. Moreover, although not as strong as the technological context, the organizational context did have an influence on adoption; perceived lack of technological knowledge was found to have a significant negative relationship. As it appears, the environmental context does not currently appear to have a significant effect on blockchain technology adoption. Perceived regulatory uncertainty, standardization uncertainty, and network enhancement were found to have non-significant relationships to intention to adopt blockchain.

The results show perceived data quality as a significant positive factor influencing blockchain technology adoption by organizations. This is consistent with prior empirical research regarding emerging technology adoption (Hsieh \& Lin, 2018; Demoulin \& Coussement, 2018; Hoxha \& Sadiku, 2019). This result is also consistent with the findings of previous qualitative blockchain studies (Altaei et al., 2018). Such a heavy emphasis on data quality is indicative of the importance of organizational data when operating in today's data-driven economy. Organizations are looking to make better use of their data and blockchain is perceived as being able to support this goal. Blockchain technology has several properties, such as the ability to reduce single-points of failure, enhance auditability, achieve a single version of the truth, and provide tamper-evidence, capable of enhancing the quality, completeness, accuracy and overall usability of an organization's data 
(Hoxha \& Sadiku, 2019; Narayanan et al., 2016; Makhdoom et al., 2019; Wang et al., 2019b). Organizations are cognizant of these blockchain properties, which has resulted in data quality being a significant driver for organizational adoption.

Perceived interoperability was also found to be a significant positive factor influencing blockchain adoption. This confirms the role of interoperability in technology adoption found by prior research; the more easily a new technology can be integrated with an organization's existing technology infrastructure, the more likely they are to adopt (Ranganathan et al., 2011; Chau \& Tam, 1997). In the context of blockchain technology, organizations perceive blockchain to be highly interoperable with their existing technology infrastructure, that is, their systems, databases and technological processes. This indicates an adopting organization would require minimal to no changes to their legacy infrastructure, which reduces the cost and time to adopt and implement blockchain technology. In addition, with high interoperability, organizations can more easily integrate their own blockchain solution with that of a partner organization. Lower cost and time, as well as being able to integrate solutions within the organization's business network makes perceived interoperability a significant driver for organizational adoption of blockchain technology. One note is that from the qualitative interviews, some of the respondents, some of who are actual adaptors, made claim that interoperability is a barrier. Yet, the respondents from our survey, who have not adopted, perceive interoperability to be a driver. It is conceivable that interoperability is perceived as a driver because the respondents have not actually attempted to integrate a blockchain solution into their infrastructure. Reality may dictate a different story.

The technology context not only consists of drivers but also contains a barrier. Perceived technological volatility was found to have a significant negative relationship to blockchain adoption. This illustrates organizations perceive blockchain technology to be recurrently changing and consistently evolving which, in turn, reduces their intention to adopt. The immaturity, rapid evolution and the multitude of existing blockchain platforms has been noted in prior research (Moezkarimi et al., 2019). Organizations would prefer to adopt blockchain technology when it has gained more maturity, as they do not want to risk wasted resources or the possibility of re-work resulting from developing or purchasing a solution today, that could be obsolete or outdated within a short period. As it seems, for widespread blockchain adoption to occur, a non-volatile, mature technology is needed. This makes perceived technological volatility a significant barrier hindering 
adoption. Additionally, a detailed review of the technology adoption literature has not revealed the same, indicating the volatility of the technology is a novel aspect to reflect upon for technology adoption.

Within the organizational context, perceived lack of technological knowledge was found to have a significant negative relationship to blockchain adoption. The higher the perception of a lack of technological knowledge, the lower the intention to adopt blockchain technology. This is in line with Kuan \& Chau's (2001) finding that non-adopter firms believe they do not have the necessary technical competence (knowledge) for adoption. It is also consistent with the findings of other qualitative blockchain studies (Altaei et al., 2019; Li et al., 2019b). Organizations do not perceive themselves as knowledgeable enough to use blockchain technology as of yet, and therefore are reluctant to adopt it. A possible explanation is that blockchain technology is complex compared to other technology, making it difficult to learn and fully understand (Hughes et al., 2019). Effective adoption requires expertise for multiple different technologies such as cryptographic hash functions, Merkle hash trees, digital signature cryptography, a distributed consensus mechanism, transactions, blocks of hashed data, the ledger (chain of blocks), a network of nodes, and a programming language (Narayanan et al., 2016). Most organizations have some level of technological knowledge; nonetheless, blockchain stipulates a certain level of specialization. For example, without a thorough understanding of cryptography (hash functions, digital signatures) and/or database structures, it is unlikely a full understanding of blockchain technology can be obtained. With a lack of the required technological knowledge, organizations will not know how to properly develop or implement a blockchain solution. Therefore, they will have a low intention to adopt, making a lack of technological knowledge a significant barrier to blockchain adoption.

Perceived regulatory uncertainty and perceived standardization uncertainty were also found to be non-significant. The uncertainty caused by lack of regulations and/or standards appear to have no influence on organizational adoption decisions for blockchain technology. One possible rational is that the organizations truly serious about adopting are finding ways to circumvent the current regulatory and standardization limitations to produce solutions. This was the case for the three organizations Lacity (2018) studied; all three found methods to continue their blockchain development despite the uncertainty regarding regulations and standards. It is also possible that organizations believe they can influence or work with the regulatory bodies in a manner that would 
allow for their blockchain solution. If an organization is an early adopter, their blockchain technology solution could set a precedence for standardization or regulations. Two of the organizations Lacity (2018) studied took such an approach. Moreover, organizations may fear that delaying their development could result in an opportunity loss of competitive advantage. In other words, they fear the competitive advantage that could have been gained by adopting blockchain will be lost if a competitor adopts first. Rather than wait for regulations or standards to be in place, they will take the risk to be early adopters. In addition, the sample also crossed several sectors, which have varying degrees of regulations and standards. Some respondents may not be accustomed to operating with regulations and standards and therefore are not considering these aspects for blockchain technology. Finally, organizations may attempt to predict the manner in which regulations or standards will be developed to create a blockchain solution that is compatible for them. For example, in the case of PII, an organization can orchestrate their blockchain so what goes on the chain is acceptable (not PII) from a regulatory perspective.

The impact of perceived network enhancement on blockchain adoption intention was found to be non-significant in this research. As discussed in the hypothesis development, blockchain technology has the potential to strengthen organizational networks in multiple way, making this a surprising result. One possible explanation is that not every blockchain solution is meant to have an effect on networks. If a potential adopting organization is looking to build a hybrid blockchain that crosses multiple business networks, than one can expect an enhancement of that network. However, a private internal blockchain may have little to no impact on networks. Another explanation could be that network enhancement is by-product of other benefits. For example, blockchain technology can provide enhanced transparency (Narayanan et al., 2016; Hughes et al., 2019) which can facilitate increased trust within a network, which improves the network. Therefore, blockchain would seem to directly effect trust, and indirectly enhance the network. This would support the testing of a more complex model that includes trust as a moderating affect, however, however the goal of the research at hand was to test direct relationships. In addition, because the sample crosses multiple industries and considers organizations of varying sizes, some organizations may consider network enhancement as a driver, while others do not see the significance. For example, an organization operating in the supply-chain industry may see network enhancing benefits while an organization in the financial industry may not. The same could be true 
for a large organization operating in a network of businesses when compared to a small organization with a very small or no network.

\subsection{Managerial Insights for Blockchain Technology Development}

Among the data collected from the interviews in Study 1 were several additional insights regarding blockchain technology development. The first insight shows which industries are developing blockchain technology and what specific use cases they are working on. The second is regarding critical cost and length factors for development, the third is concerning future directions. This information is presented here to enhance organizational awareness and effectiveness in the event they decide to adopt (develop or work with) blockchain technology in the future.

What industries are developing blockchain technology solutions and what are the specific use cases they are working on?

A total of 14 different industries and over 45 unique use cases were recognized among the interviewees. This includes the industries our sampled organizations operate in, provide services for, or acknowledged. The use cases listed are either a work in progress, fully developed, being investigated, and/or was previously investigated by themselves or others. Table 7 summarizes the industries and use cases.

\begin{tabular}{|c|c|c|}
\hline No. & Industry & Use Cases \\
\hline 1 & $\begin{array}{l}\text { Healthcare and } \\
\text { Pharmaceutical }\end{array}$ & $\begin{array}{l}\text { - } \text { Electronic Prescribing - Tagging, tracking, and recording of prescriptions } \\
\text { - } \quad \text { Pharmaceutical Drug Tracking - Drug provenance } \\
\text { - } \text { Medical and Financial Guideline Automation - Reimbursement and } \\
\text { - Connecting Medical Practitioners and Medical Information - Doctors, nurses, } \\
\text { patients, pharmacists, government entities, and other health care practitioners } \\
\text { all sharing a common database } \\
\text { - } \quad \text { Medical Record Management - Storage, access control, and verification } \\
\text { - Medical Consent Management - Storage and verification of granted and } \\
\text { - } \quad \text { revoked consent } \\
\text { rules and guidelines }\end{array}$ \\
\hline 2 & $\begin{array}{l}\text { Information } \\
\text { Technology }\end{array}$ & $\begin{array}{l}\text { - Social Credit/Commitment Scheme - Individuals make promises and are } \\
\text { rewarded for keeping them. This earns them badges (tokens) which are } \\
\text { tradable } \\
\text { Digital Identity Management and Authentication - Creation of a single digital } \\
\text { identity which is portable for the use of services }\end{array}$ \\
\hline 3 & Public Services & $\begin{array}{l}\text { - Credentialing and Licencing - Creating, managing, regulating, enforcing, and } \\
\text { verifying credentials and licences (business licences, liquored licences, } \\
\text { restaurant licences, and city planning licences) } \\
\text { Identity Theft Reduction - Having credentials and licences stored on a } \\
\text { blockchain, attached to a digital identity, allows for identity theft to be } \\
\text { combatted more effectively. }\end{array}$ \\
\hline
\end{tabular}




\begin{tabular}{|c|c|c|}
\hline No. & Industry & Use Cases \\
\hline & & $\begin{array}{ll}\text { - } & \text { Food Supply Chain Provenance - Tagging, tracking, and recording food from } \\
\text { - } & \text { Source to destination for disease and contamination control } \\
\text { - } & \text { procurement Management -Tagging, tracking, and recording materials and } \\
\text { - } & \text { Lobbyist Registry - Recording and verification of lobbyist groups } \\
\text { - } & \text { Book of Records for Public Disbursement and Management of Funds } \\
& \text { (innovation funds, grants, and other public contributions) } \\
\text { - } & \text { Book of Records for Land Registry, Health Cards, Marriage Licences, and } \\
& \text { Tickets (traffic and other tickets) } \\
\text { - } & \text { Immigration and Refugee Tracking } \\
\text { - } & \text { Asset Tagging, Tracking, and Recording } \\
\text { - } & \text { Digital Identity Management } \\
\text { - } & \text { Digital Voting } \\
\text { - } & \text { Social Services Management - Recording of fund distribution and activities } \\
\text { - } & \text { Regulation-Technology (Reg-Tech) - A means of ensuring compliance with } \\
& \text { regulations by recording and auditing activities } \\
\text { - } & \text { Tenant Management - Records of occupancy and facilitation of payments } \\
\text { - } & \text { Citizen Management } \\
\text { - } & \text { Veteran Affairs Management } \\
\text { - } & \text { Library and Archives Management } \\
- & \text { Taxation - Recording, Auditing, and Facilitating Returns and Payments } \\
\end{array}$ \\
\hline 4 & $\begin{array}{l}\text { Financial/ } \\
\text { Banking }\end{array}$ & $\begin{array}{ll}\text { - } & \text { Digital Payments and Cryptocurrencies - Cross border payments, long } \\
\text { running transactions, smart contract automation for predictable and repeatable } \\
\text { transactions, and tokenization of currency } \\
\text { - } \quad \text { International Remittances } \\
\text { - } & \text { Stock and Bond Tokenization } \\
\text { - } & \text { Post-Trade Settlement and Reconciliation } \\
\text { - } & \text { Re-Engineering Commodity Financial Processes - Know Your Customer } \\
& \text { (KYC) and Anti-Money Laundering (AML) regulatory compliance recording } \\
\text { and auditing } & \\
\text { - } & \text { Connecting Books of Records for Consumer Lending } \\
- & \text { Asset Tagging, Tracking, and Recording - For information technology and } \\
\text { - } & \text { other assets } \\
\text { - } & \text { Cryptocurity Token Offerings - Raising capital } \\
\end{array}$ \\
\hline 5 & $\begin{array}{l}\text { Supply Chain } \\
\text { and Logistics }\end{array}$ & $\begin{array}{ll}\text { - } & \text { Asset Tagging, Tracking, and Recording - Shipping containers } \\
\text { - } & \text { Food Tagging, Tracking, and Recording - Providing provenance to aid } \\
\text { disease and contamination control } \\
\text { - }\end{array}$ \\
\hline 6 & $\begin{array}{l}\text { Human } \\
\text { Resources }\end{array}$ & $\begin{array}{l}\text { - Talent Acquisition - Storing and managing academic, employment and other } \\
\text { credentials on a blockchain for employer verification }\end{array}$ \\
\hline 7 & Real Estate & $\begin{array}{ll}- & \text { Mortgage Applications and Transactions } \\
- & \text { Combating Fraud }\end{array}$ \\
\hline 8 & Energy & $\begin{array}{ll}- & \text { Micro Transactions of Electricity } \\
- & \text { Electrical Disbursement Optimization and Efficiency Enhancement } \\
\end{array}$ \\
\hline 9 & Creative Arts & $\begin{array}{ll} & \text { Book of Records for Digital Rights Management (music rights) } \\
\text { - } & \text { Digital Time Stamping - Proof of authorship, action, or anything else which } \\
\text { requires irrefutable proof of ownership or creation (such as art ownership) }\end{array}$ \\
\hline 10 & Arms & - $\quad$ Tokenization of Firearms for Enhanced Management and Control \\
\hline 11 & Insurance & - $\quad$ Parametric Insurance Offerings \\
\hline 12 & Law & $\begin{array}{ll}- & \text { Storage and Verification of Wills and Testaments } \\
\text { - } & \text { Storage and Verification of Patents }\end{array}$ \\
\hline 13 & $\begin{array}{l}\text { Non-Profit } \\
\text { (Charity) }\end{array}$ & - Secure Disbursement and Tracking of Charitable Funds \\
\hline
\end{tabular}




\begin{tabular}{|c|c|c|}
\hline No. & Industry & Use Cases \\
\hline 14 & Luxury Goods & $\begin{array}{l}\text { - } \begin{array}{l}\text { Tracking, Tagging, and Recording - Ensuring authenticity of the product to } \\
\text { combat fraud }\end{array}\end{array}$ \\
\hline 15 & Social Media & $\begin{array}{ll}\text { - } & \text { Combating Fake News Using Blockchain's Transparency and Distributed } \\
& \text { Consensus } \\
\text { - } & \text { Endorsement Platform for Job Candidates and Professionals } \\
\text { - } & \text { User Rewards for Content Engagement for Brands }\end{array}$ \\
\hline
\end{tabular}

Table 7 - Industries and Use Cases

A window to the current blockchain development landscape provides executives with valuable information when determining two important facets of organizational strategy: how can blockchain support the organizational strategy and how will blockchain change the organizational strategy?

Understanding how blockchain can support an organizational strategy is an important first step for organizations considering an approach for blockchain development (Felin \& Lakhani, 2018). Yet, before this can happen, one must understand what blockchain can do. Having knowledge of the industries and use cases, as provided by Table 7, allows managers to know what blockchain is capable of doing. It canvases the art of the possible. This is a critical first step to understanding its applicability to the organization. If an organization is unaware of blockchain technology's capabilities, they will be unable to explore how it can support their strategy and provide value.

Knowledge of the industries and use cases will also help organizations understand how blockchain technology will influence their organizational strategy. With this information, management can identify market opportunities, competitor positions, and disruption potential. Organizations can answer important questions such as:

- Are we at risk of being disrupted?

- Are competitors or new entrants within our industry developing blockchain solutions?

- Are members of our supply chain or value chain innovating within the blockchain space?

- Are there collaborative opportunities to co-create value?

- Will one or more of these use cases provide value for our customers or us?

- Should we build or buy a solution?

For example, if an organization is traditionally a purchaser of technology, as opposed to a developer, understanding the blockchain development landscape allows them to avoid re-inventing 
the wheel. In other words, time and other valuable resources can be saved by purchasing an existing solution rather than learning and developing it on their own. In another scenario, the development landscape may reveal use cases within one's own industry, indicating a competitor or new incumbent is innovating. This may signal a need to begin their own development or risk losing a competitive advantage or market share. In addition, an organization may realize that no use cases are being developed in their industry, demonstrating a new opportunity to create value. Whatever the case, enhanced market transparency is valuable information for any organization considering developing blockchain technology or attempting to remain competitive in the coming blockchain era.

What factors are contributing to the cost and length of development?

The average cost across the interviewees was $\$ 1,409,590$. The average length was 18 months. However, a significant amount of cost and length variability existed among the interviewees. As such, a meticulous analysis was conducted to discover the factors responsible for various cost and length structures among the sample. One note is that these factors are highly interrelated and contextual, with factors influencing each other, and trade-offs exist. Table 8 outlines the cost and length factors.

\begin{tabular}{|c|c|c|}
\hline No. & Factor Name & Breakdown \\
\hline 1 & Approach & $\begin{array}{l}\text { Partnerships vs Internal Development } \\
\text { - } \quad \text { Partnering with skilled blockchain solution providers, consultants, or external } \\
\text { organizations helps reduce development length and cost } \\
\text { - } \quad \text { Developing internally without external support can increase the length and cost }\end{array}$ \\
\hline 2 & Employees & $\begin{array}{l}\text { Skills/Knowledge } \\
-\quad \text { Having current employees who are experienced and knowledgeable may decrease } \\
\text { the length and cost } \\
\text { - } \quad \text { Training current employees or hiring the needed talent can increase length and cost } \\
-\quad \text { Volunteer work or student internships may reduce cost } \\
\end{array}$ \\
\hline 3 & Organization & $\begin{array}{l}\text { Size and Structure } \\
\text { - The number of validations, approvals, and clearances, following well-defined rules } \\
\text { and processes, needed to secure project resources and the freedom to operate can } \\
\text { increase the length and cost. With large organizations, that have a well-defined } \\
\text { structure, the project needs approval by several groups such as development, } \\
\text { security, enterprise architecture, quality assurance, operations which all have their } \\
\text { own set of rules and validations. This compounds the length and cost } \\
\text { - Start-ups and small-to-medium organizations have more options and agility. For } \\
\text { example, less approvals needed, or the founder, temporarily, not being paid. With } \\
\text { more options at hand, these organizations can reduce the length and cost } \\
\text { Current Level of Understanding of the Organization's Processes and Infrastructure } \\
\text { - A deep understanding of an organization's own processes and infrastructure can } \\
\text { reduce the length and cost of developing and integrating a blockchain solution, as }\end{array}$ \\
\hline
\end{tabular}




\begin{tabular}{|c|c|c|}
\hline No. & Factor Name & Breakdown \\
\hline & & $\begin{array}{l}\text { the organization will be aware of the solution's impact on operations and how it } \\
\text { will fit with the organization } \\
\text { Adequacy of The Organization's Current Technology Infrastructure } \\
\text { - Legacy infrastructure can be baggage, hindering the pace of implementation and } \\
\text { increasing the cost (through upgrades or additional integration costs) } \\
\text { Changing Business Models } \\
\text { - Transformational use cases may require a change in the organization's business } \\
\text { model, which takes a significant amount planning and strategic thinking. This } \\
\text { drastically increases the development cost and length } \\
\text { Documentation } \\
\text { - The more complex the solution, the more difficulty documenting it, which } \\
\text { increases the length and cost } \\
\text { Limited Resources and Prioritization } \\
\text { - With limited resources and the novelty of blockchain, project prioritization can } \\
\text { slow the pace of development. For example, upgrading a legacy system may have } \\
\text { higher priority than developing a new blockchain system } \\
\text { Other Organizational Factors } \\
\text { - Turnover can increase length and cost }\end{array}$ \\
\hline 4 & Complexity & $\begin{array}{l}\text { Number of Use Cases/Features/Functions } \\
-\quad \text { More functionality adds length and cost } \\
\text { - } \quad \text { Security considerations such as encryption can increase the length and cost } \\
\text { - Identity management complexity and trust algorithms can increase the length and } \\
\text { cost } \\
\text { Number of Stakeholders } \\
\text { - The less stakeholders involved in the solution the less expensive and faster the } \\
\text { development } \\
\text { - Having more stakeholders increases the length and cost: } \\
\circ \text { Requires coordinated decision making such as establishing shared } \\
\text { governance. } \\
\quad \text { All other length and cost factors described in this table are compounded } \\
\text { as per the number of stakeholders. } \\
\circ \quad \text { Requires vetting of potential partnerships. } \\
\quad \text { Requires connection of the stakeholders, which requires application } \\
\quad \text { programming interphases, user interphases, and system integration. } \\
\circ \quad \text { Geographical dispersion of stakeholders. } \\
\circ \quad \text { Stakeholder industry considerations such as standards, laws, and } \\
\text { regulations } \\
\text { Application Integration } \\
\text { Number of applications to integrate and number of application rules. More } \\
\text { applications and application rules result with longer and more costly development } \\
\text { State of the application (legacy or modern). Legacy increases length and cost }\end{array}$ \\
\hline 5 & Learning & $\begin{array}{l}\text { Blockchain Technology is Complex and Being Developed Rapidly, Making a Full } \\
\text { Understanding a Moving Target } \\
\text { - } \quad \text { Having experience with and a full understanding of blockchain technology can } \\
\text { expedite development and lower costs } \\
\text { - } \quad \text { Organizations without experience and a full understanding need to take time and } \\
\text { spend money to understand the risks, costs, and benefits of blockchain technology }\end{array}$ \\
\hline
\end{tabular}




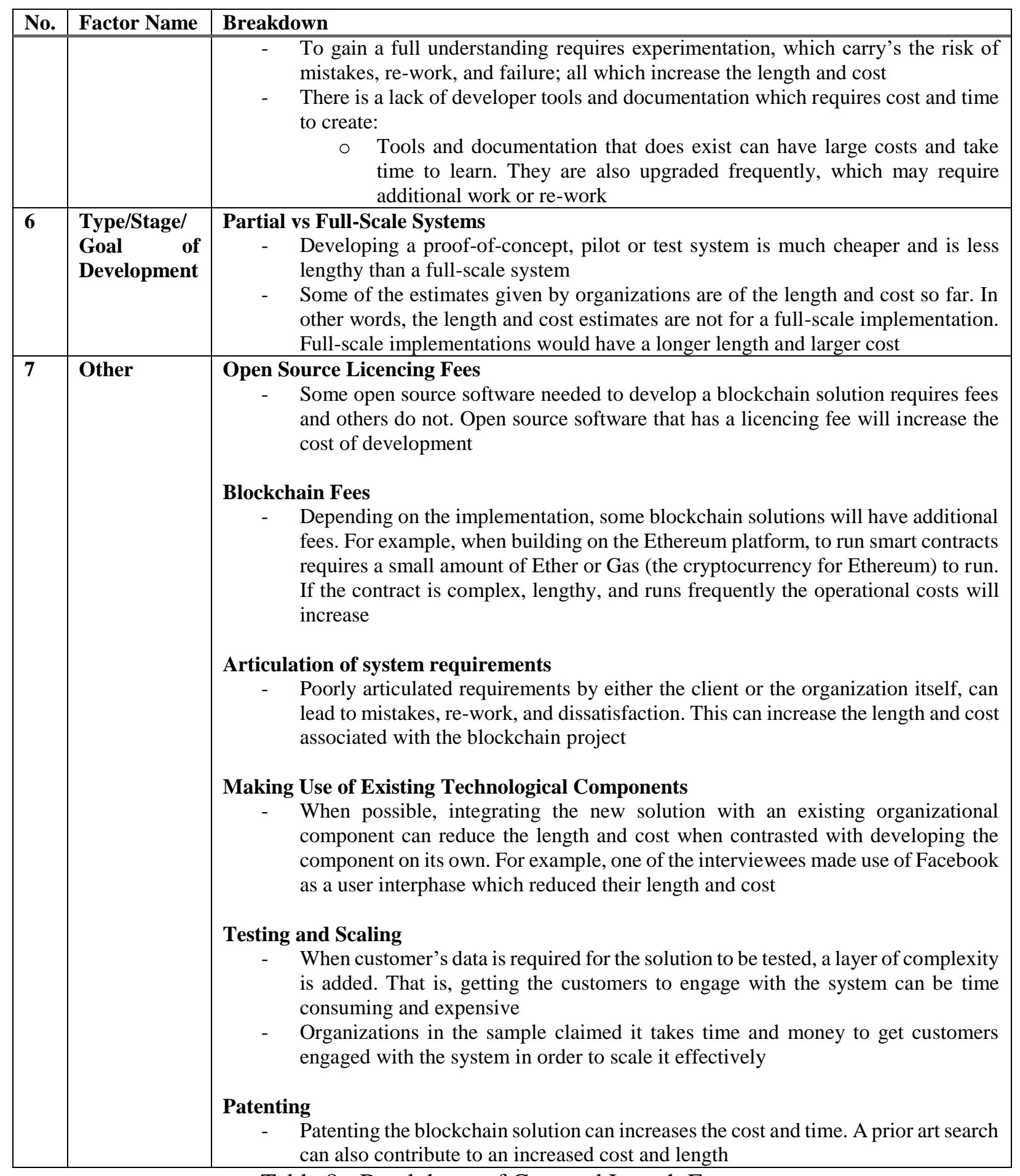

Table 8 - Breakdown of Cost and Length Factors

Analysis of the length and cost factors has revealed several intriguing insights, which can aid organizations with their own development of blockchain technology. 
First, relating to the approach and employee skill level, an organization must understand its own capabilities and resources. Once the organizational strategy has been considered, management should turn to their own capabilities, as dictated by prior work (Felin \& Lakhani, 2018). Organizations must question their ability to develop a real solution when selecting an approach to development. If employees lack the knowledge and skills to develop the technology, collaborating with an external provider may reduce the length of the project and possibly the cost. Although one may argue that developing internally can reduce the cost, the potential for re-work, and the need for learning/education can increase both the time and cost. This is not to say that the organization should not learn the technology themselves or have the provider do all the work. It is to say the organization should work with the provider to learn, reduce the project's length, and lower the project's cost.

Second, regarding organizational factors, most interviewees attributed the bulk of length and cost to business (organizational) related issues, rather than to blockchain (technological) itself. One interviewee estimated that $80 \%$ of the length and cost was attributed to business related issues while $20 \%$ was related to blockchain technology. It was not the actual coding, but rather the number of validations, approvals, and clearances, rules and processes that needed to be followed to secure project resources and the freedom to operate that increased length and cost. In addition, the organization's absent understanding of their own processes and infrastructure, the inadequacy of the organization's current technological infrastructure as well as changing business models added significant length and cost to projects. Other factors, such as open source licensing fees, blockchain specific fees, articulation of business requirements, making use of existing technological components, testing and scaling, and patenting are somewhat out of the control of the organization and less impactful, but do influence the cost and length of development. Knowing this, organizations should seek to develop more agility for projects dealing with modern technology such as blockchain. The development/decision making process (validations, approvals, clearances, defined rules, and processes) should be updated to be more accommodating and streamlined. Agility is also important for continued maintenance as blockchain technology is being developed rapidly; another major cost and time implication (See Table 8). This way, as blockchain technology matures, the organization can adapt more easily. Perhaps the organization can create a dedicated group, to develop emerging technology that is given the necessary freedom to create solutions. In addition, organizations need to obtain a thorough understanding of their own 
processes and technological infrastructure before development to allow them to comprehend blockchain's impact on operations, how blockchain can fit with the organization, avoid re-work, and circumvent complexities. Finally, organizations should consider acquiring/purchasing the required infrastructure from an external provider if their current infrastructure is incapable of incorporating blockchain technology.

Another major source of increased length and higher costs is the complexity or scope of the solution. Simply put, more complexity (number/type of features/functions, number of stakeholders involved, and the level of integration required) equates to extended length and increased cost. During our interviews with the blockchain consultants/product venture firms (those organizations who have developed solutions for clients), it was noted that most of the functions being developed were not used. Like the breakdown of length and cost for business versus technological issues ( $80 / 20$ scenario), only $20 \%$ of the functions were being utilized by $80 \%$ of the users. Knowing this, managers should scope projects down to reduce the complexity and in turn, reduce the length and cost. Management has several options to address this. They can speak with future users of the blockchain system to truly understand their needs. This will help avoid developing unused or underused features. The organization could also start with a small/single entity use case that requires little internal integration and is done with the support of a provider. This not only addresses the complexity issue but the 'type of development' and 'learning' issues (see Table 8). Organizations should first work on a pilot or minimum viable product, then, in the future, they can develop a full-scale solution. This way organizations learn and develop simultaneously, as the technology matures. When the market is right and technological maturity has been achieved, the organization will be well positioned for larger and more complex use cases. This also gives the organization time to test procedural changes as they seek to create more agility in the development process and elicit feedback from the systems users. In other words, organizations have an opportunity to learn blockchain technology, test the solution with users, and validate the procedural changes concurrently.

What are the future directions for blockchain technology?

When inquiring about the future direction of blockchain technology, the interviewees highlighted several insights. After synthesizing the insights, five themes were developed; 
abstraction, consolidation/standardization, technical integration, emerging scenarios, and intermediary evolution. This section concludes with some long-term views.

Abstraction. Blockchain technology is going to disappear, however, not in the way one might think. The technology itself is not going anywhere, but rather it will become invisible. Our interviewees described a future where blockchain is a hidden underlying component for business everywhere. New products and services will be offered that have a blockchain component, but blockchain will not be the highlight. The question will not be; are we, our customers or partner organizations going to adopt a/our blockchain solution? It will be; are we, our customers or partner organizations going to use this new product or service that serves an organizational or customer need? Its not about the technology itself, it is about the value it can create. It just so happens that the new product or service has a blockchain component. Picture the internet. Are individuals or organizations going around saying 'this Transmission Control Protocol/Internet Protocol (TCPIP) is great; it really enhances our business'? No, they simply refer to it as the Internet. Just as TCP-IP was hidden, blockchain will be too. Blockchain will be hidden not only from a marketing perspective but also from a complexity perspective. The complexity of blockchain will be abstracted behind a layer of user interphase/ease of use. Users of the blockchain solution will see no difference from a mobile application today and a mobile application using blockchain tomorrow. They will just receive the benefits of blockchain unknowingly.

Consolidation/standardization. Currently, everyone wants to be the 'blockchain for digital rights, supply chain provenance, identity management, healthcare records, and the list goes on. There is a multitude of different organizations trying to provide the same blockchain services, with results in a highly fragmented market. Individual organizational commercial interest combined with the lack of regulation and standardization were described as the major culprits of the fragmentation. There cannot be fifty organizations attempting to provide the same market the same services. This makes consolidation/standardization is inevitable. Eventually, there will be winners and losers. However, organizations can consider collaboration, teamwork and co-creation to ensure survival. Much of blockchain's power is a function of the network. Hybrid blockchains are, as described by our interviewees, where the real benefits of blockchain lie, making collaboration an interesting proposition. In sum, consolidation/standardization is expected, so organizations 
should be thinking about their unique value proposition sooner rather than later or consider collaborating with similar organizations.

Technical integration. Blockchain is not a silver bullet that will solve all an organization's woes. It was described as another technological tool in the toolbox to support the organization and it will be only one element in a solution. It will not be used in isolation to solve every problem. An acceleration of benefits occurs when blockchain is combined with other technology and a robust support infrastructure. For example, the combination of the Internet of Things (IoT) technology and blockchain can result in innovative and valuable solutions. IoT sensors collect that data and blockchain acts as an immutable data store and can provide automation capabilities. Several use cases are being investigated that combine these two technologies such as: patient sensors monitoring their health, vehicular communication, environmental wireless sensor networks, smart grids (electrical wireless sensor networks), and asset tagging, tracking, recording. For a detailed account of blockchain and IoT see the work by Christidis \& Devetsikiotis (2016) and to examine a real use case already in production, see the work done by Maersk for their shipping containers (Li, 2017) Blockchain and IoT solutions are just one example of combining technology for greater results. Machine learning (ML) and artificial intelligence (AI) are also being combined with blockchain technology. The potential has only just begun.

Emerging scenarios. The first use cases to market will be single entity use cases, as opposed to those involving multiple organizations or those that require a significant customer base for success (those that require customer data to operate). These use cases will likely solve an existing problem or create improvements to existing operations and take the form of private-permissioned blockchains. However, they will be a small percentage of blockchain technology's overall projected value. Consortium blockchains (those that involve multiple organizations being connected for business by a blockchain) that solve existing problems, will come later due to the additional coordination efforts required and these solutions will have more value. The real bulk of value will be the new use cases, business models, business networks, or business ecosystems enabled by blockchain technology, that use blockchain for its true inherent value (such as multiparty trust scenarios) and are aimed at solving problems that may not yet exist. With more experience, deep learning, and maturation of the technology comes a real understanding and then, the new business models, use cases, and applications that have not been thought of before will 
start. It may be a small company or a combination of small companies who create these revolutionary solutions, as they do not have the baggage and legacy infrastructure that large organizations deal with. This gives them substantially more freedom to innovate. These solutions will disrupt big players in large industries, and this will tip the domino or begin the snowball. In other words, these solutions will capture real interest and provide traction for significantubiquitous adoption.

Intermediary evolution. A final theme was about the impact blockchain technology will have on intermediary or broker organizations and manual jobs. Blockchain technology is often cited as having the power to disintermediate the intermediary organizations such as payment processors, real-estate brokerages, insurance companies, auditing organizations, estate law firms and others. It is also cited as being able to automate (using smart contracts) and therefore remove several types of manual jobs. Our interviewees believed that these types of organizations and jobs will be impacted but not outright disappear. The manual jobs will be severely reduced, rather than become extinct but this is not only a function of blockchain. Other emerging technology such as artificial intelligence and machine learning play their role in manual job reduction as well. With the intermediary organizations, they are more likely to adopt and use blockchain technology before they are completely disintermediated. They will need to re-invent to remain relevant. It is conceivable that some intermediary organizations believe that blockchain is a passing technological fad, resulting in a lack of research and development but the smarter businesses will not become the next Blockbuster. As the saying goes, if you cannot beat them, join them and this was the position of our interviewees. In sum, manual jobs will be severely impacted, but intermediary organizations, if they adopt and use blockchain technology, are poised to survive.

At a higher level, most interviewees believed blockchain technology has the power to positively revolutionize the world, but they did not believe blockchain technology will be the sole reason or be given all the credit. As discussed above, blockchain technology will be another technological tool available to organizations for their operations. It will be combined with other technology and hidden under the surface. On the other hand, a few interviewees believed that blockchain would be at the forefront of the future. However, this was not the most popular view. In short, the hype will die but blockchain technology will become ubiquitous.

What does the next 10 years hold for blockchain technology? 
Before concluding each interview, opinions about the future of blockchain technology for the next five to ten years were elicited. Several intriguing insights were discovered and are summarized in Figure 3 below. 


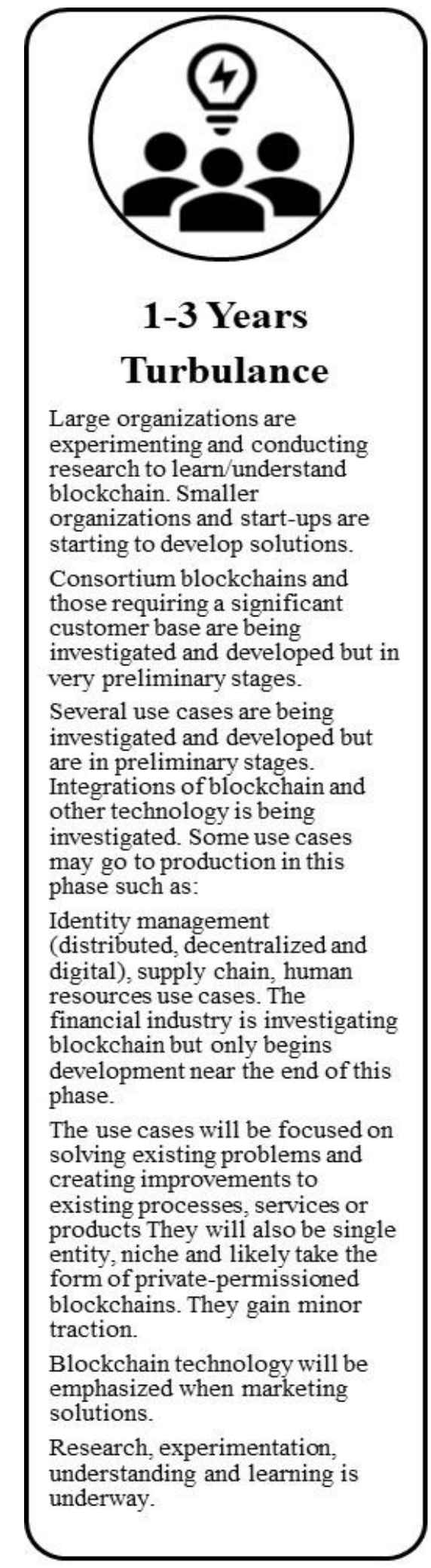

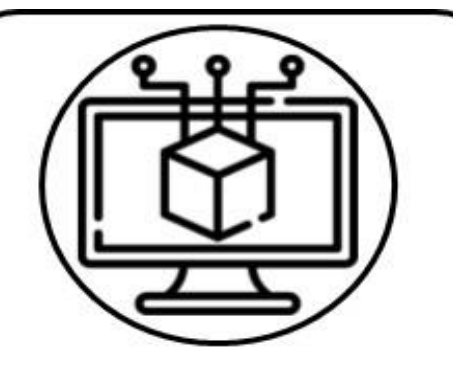

\section{4-6 Years \\ Development}

Larger organizations slow experimentation and start developing real solutions. Smaller organizations and startups continue to develop solutions.

The use cases from the 1-3-year mark progress further with some being finalized and gaining traction.

More production-level and successful use cases are being used in industries such as; financial, healthcare, insurance and even public services (digital voting). This will bring enhanced transparency to the applicable benefits of blockchain technology.

The use cases are still mostly private-permissioned blockchains.

Consortium blockchains and those requiring a significant customer base continue to develop, are gaining maturity and some are being used.

Complexity is being abstracted behind a layer of ease of use (user interphase). Blockchain technology is also being integrated with other technology.

New, never seen before use cases, business models, and applications will start but are in a very preliminary stage. The snowball begins.

Blockchain technology is starting to be de-emphasized when marketing solutions.

Research, experimentation, understanding and learning is maturing.

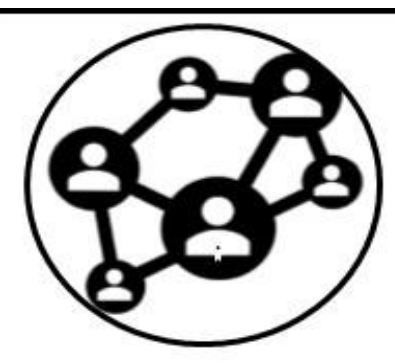

\section{7-10 Years}

\section{Realization}

Significant traction is being achieved.

Blockchain is a significant component for large organizations and is playing a support role.

Consortium use cases and those requiring a significant customer base for successful outcomes are maturing and being used.

New, never seen before use cases, business models, business networks and applications are maturing and being developed. They will start to go to production and be available in this stage. The snowball continues.

Experimentation, research and development, learning and understanding is mature. Many of the current problems with blockchain have been solved.

The complexity of blockchain technology is fully hidden and it is has been integrated with other technology.

Organizations whom have not been experimenting and learning will start but are far behind.

Many intermediary and broker, organizations as well as manual jobs will be reduced and/or become automated in this stage.

Blockchain technology is not emphasized at all when marketing solutions.

Business models based on blockchain, and its applications are maturing and are continuing to be developed.

Figure 4 - Blockchain Technology Timeline 
Blockchain technology holds the promise of drastically revolutionizing business ecosystems around the globe. The coming decade is predicted to be when considerable development will start, and real value will be obtained. As such, now is the time for organizations to begin researching, learning, experimenting and developing.

The bridge between development and the realization of blockchain technology for organizations should be more translucent, as this research has discussed the development landscape, important cost and time implications, future directions, and provided several useful recommendations. Knowledge of the industries and use cases provides organizations with a window to the current development landscape. This should be used for strategy development, to understand blockchain's capabilities, and to identify market opportunities, competitor positions, and disruption potential. The breakdown of length and cost factors imply organizations should consider developing with the support of a provider, incorporate agility for blockchain projects, update the development/decision making process (streamline validations, approvals, clearances, rules, and processes), obtain a thorough understanding of their own processes and technological infrastructure, acquire/purchase the required infrastructure from an external provider and scope projects down to reduce complexity.

In addition, with an understanding of blockchain's future directions, organizations should take pre-emptive action to facilitate effective development. Knowing blockchain will be abstracted, organizations should begin to emphasize the value of the solution rather than focusing on the blockchain component. Action should be taken to develop blockchain in a collaborative manner to be well positioned for the unavoidable consolidation of solutions. Experimentation and exploration need to consider a combination of blockchain and other emerging technology, as technical integration appears inevitable. Finally, organizations need to be aware of the emerging use case scenarios and their relative position in the market (if they are an intermediary) to avoided disruption.

Skeptics of blockchains value and those who believe it is only hype will wait too long. It is not a passing fad nor just hype. It is real, here to stay, and will prove to be a critical cornerstone of organizations' technology infrastructure for the near future. Those preparing now, will thrive in the new blockchain era and truly reap the benefits. Those who continue procrastinating will be left in the dust. 


\section{Chapter 4 - Theoretical and Practical Implications}




\subsection{Theoretical Implications}

Several theoretical contributions have been made by this research. A new theoretical framework of the factors influencing blockchain technology's adoption has been developed and empirically tested. The factors within this framework were identified from primary data, as opposed to secondary sources, collected from 25 interviews with 23 different organizations. The factors were then empirically tested with 146 employees from 71 organizations. The framework is a novel contribution as it presents a holistic perspective of blockchain adoption, as opposed to some prior studies focusing on the adoption of a single function/feature of blockchain such as cryptocurrency (Almarashdeh, 2018; Jonker, 2019). In addition, the framework comes at a critical time, as organizations are beginning to investigate blockchain technology on a larger scale and the blockchain market is set to drastically expand in the coming decade (Granetto et al., 2017).

The new adoption framework contains four factors that were found to significantly influence organizations' behavioural intention to adopt blockchain technology; two drivers and two barriers. The findings support and validate several factors influencing blockchain adoption and contribute one novel factor. Perceived technological volatility represents a novel contribution in two ways. First, a review of the technology adoption literature has not revealed a prior study that has considered how the volatility of a technology directly influences organizational adoption decisions. This provides a new perspective to consider for future research analyzing technology adoption. Second, a new empirically validated scale was developed to measure an organization's perceptions of a technology's volatility. This allows future researchers to make use of the scale directly or adapt it for their own adoption context. The framework and novel adoption factor extend the existing literature about technological adoption, specifically blockchain adoption, and the literature on blockchain technology in general.

Another unique contribution lies in the methodological approach taken. At the time of writing, no other blockchain technology adoption study employed a mixed methodology, in the manner taken for this research. Most prior blockchain adoption research takes either a qualitative or a quantitative approach. This research combined both approaches by first conducting qualitative interviews to identify the factors and then making use of a quantitative survey to empirically validate them. By taking this approach, a more complete and detailed understanding of organizations' blockchain technology adoption behaviour is achieved.

Furthermore, the sample used to collect data is unique within the blockchain adoption 
literature. Unlike most previous research focused on a single sector and sampled non-adaptors, the sample used in Study 1 crosses 12 unique sectors and includes both organizations that have adopted blockchain technology and those who have not. The sample from Study 2 crosses nine unique sectors. Crossing multiple sectors and eliciting perspectives from organizations with first hand experience allowed for a more accurate, detailed and holistic discovery of the blockchain adoption factors. This created a deeper understanding of blockchain technology adoption.

\subsection{Practical Implications}

The results show organizations currently perceive that their employees lack the technological knowledge needed to adopt blockchain technology. The clear implication is to implement a training and awareness program to ensure employees not only have the knowledge to adopt blockchain but also successfully make use of it. Marler, Liang \& Dulebohn (2006) show that the extent of employee training has a direct positively relationship to intention to adopt information technology, showing the effectiveness of training. Incentives should be offered to employees who excel in the program to ensure active learning takes place and a real understanding is gained. Furthermore, organizations developing blockchain solutions for other organizations to adopt should recognize their potential clients may be lacking the knowledge required to adopt. To address the knowledge gap, they should offer supplementary education materials, training and support services with the sale of their blockchain products. Alternatively, the organization's development of blockchain technology could encapsulate some of the complexity within a layer of user interphase. A similar notion goes for blockchain consulting firms: consider developing an education and training program or method to ease the complexity to offer the organizations using ones services. A formal, structured, and properly developed blockchain technology curriculum could become a lucrative new avenue of consultation services to be offered. Whether it is the organization adopting, the organization providing blockchain services, or a blockchain consulting firm, the creation of education and training materials will help bridge the knowledge gap. The more technological knowledge an organization has, the more likely they will be to adopt (Ifinedo, 2011; Lin \& Lin, 2008; Thong, 1999).

To drive through the technological volatility, organizations should seek to first understand the blockchain development and innovation landscape as best they can. Understandably, attempting to know every development direction, or all of the blockchain platforms that exist is difficult, but 
the more an organization understands, the better equipped they are to make adoption decisions. Next, organizations should achieve a clear understanding of their own strategy, their capabilities/resources, and the problems they want solve for their stakeholders (Felin \& Lakhani, 2018). Then, with an understanding of the blockchain development landscape and one's own strategy, capabilities and stakeholder problems, an organization can more accurately make adoption decisions. They can cut through the maze of irrelevant solutions, useless features and poorly designed platforms to make the best adoption decision for themselves and their stakeholders. This goes for both purchasing a decision and developing it internally. In addition, the organizations developing their solution internally or with a supporting firm should seek to build highly agile and interoperable blockchain solutions. That way, as the technology matures, new features or functions can more easily be incorporated into the existing solution. Organizations will be better prepared for major technological changes. Another option could be to start development with a pilot or minimum viable product (MVP). This allows an organization to experiment and learn, aiding with the lack of technical knowledge, and develop at the same time, while blockchain technology matures. Then, with a mature technology, the organization will be well positioned to take their pilot or MVP to a production-level environment.

Knowing data quality is a significant driver of blockchain adoption can aid blockchain consultant firms and blockchain development organizations when providing their services or products. The blockchain development firms should highlight the data enhancing qualities of blockchain technology when marketing their products. Blockchain consulting firms can better tailor their services provide higher quality consultations by aiding organizations with their understanding of how blockchain can enhance their data. Moreover, blockchain researchers should continue to investigate methods to further improve the data enhancing qualities of blockchain technology to promote ubiquitous adoption.

Finally, knowing interoperability is positively associated with a behavioural intention to adopt blockchain should inspire organizations with non-interoperable technological infrastructures to develop more interoperability. Organizations should consider that blockchain might be the mediating technology to interoperate with another organization. It can be used to connect organizations. Not only should an organization consider its own technological infrastructure but it should consider the interoperability of vendors, partners and any other external organizations' 
infrastructure needs to be considered. Indeed, being aware of the interoperability of the network one operates in is critical. In addition, the organizations with highly interoperable infrastructures should seek to continue to develop or purchase technology compatible with existing technology and that is agile. 
Chapter 5 - Limitations and Future Research 
This research has some limitations, despite its theoretical and managerial implications, that lay the foundation to which perspectives can be opened for future research.

First, this research focused on North American organizations. Future research can attempt to discover blockchain technology's adoption factors with a sample representing a wider geographical distribution to achieve greater generalizability. Another option could be to consider a cross-country analysis, in particular, examining how socioeconomic differences shape blockchain adoption decisions. In addition, although the sample in this research is reasonable, future research could empirically validate the blockchain adoption factors with a larger sample of organizations.

Second, data was collected from numerous organizations ranging in size and industry classifications. The diversity of size and industry may affect the technology adoption decision. Future research could attempt to analyze the difference in blockchain adoption intention based on these factors. For example, one could analyze the difference in adoption intention between large and small organizations or cross analyze organizations in the supply chain and financial industry.

Third, this research hypothesized direct relationships between the antecedent adoption factors and dependent variable. This was to create a theoretical base to which additional relationships can be investigated. Future research could analyze the model differently to identify any potential moderating or mediating effects. For example, it is conceivable that perceived data quality has a moderating effect on perceived interoperability. The more relationships discovered, the more detail known about organizational adoption of blockchain. The more known about organizational adoption of blockchain, the more known about technological adoption.

Future research may also conduct in-depth case studies to understand how organizations contend with and overcome the barriers hindering blockchain's adoption. Lacity (2018) performed such an analysis for four barriers of blockchain adoption. The barriers discovered in the research at hand, perceived technological volatility and perceived lack of technological knowledge, provide new opportunities to analyze how organizations cope when adopting blockchain.

One final avenue of future research could be to conduct a longitudinal study considering how the adoption landscape changes over time. Blockchain technology is rapidly developing, meaning the technology, organizational, and environmental, factors may change. A longitudinal 
study could capture these changes. Furthermore, a study of organizations' blockchain continuance intention would shed new light into post-adoption behaviour and provide a more holistic picture of the adoption phenomenon. 
Chapter 6 - Conclusion 
This research has examined the factors influencing organizational adoption of blockchain technology in an attempt to develop a theoretical framework that furthers ubiquitous adoption. A mixed methodology was used to address the adoption factors for blockchain technology. First, Study 1 employed a qualitative exploratory multiple-case study in the form of 25 interviews with 23 different organizations to discover the factors from primary data. This was to achieve a first hand account of the factors from organizations actually engaged in blockchain technology development. A total of 15 factors and three sub-factors were discovered from a content analysis of the interviews. Then, Study 2 used a quantitative survey to empirically test seven of the factors discovered with 146 employees from 71 organizations. SEM was used to analyze the results. The findings support and validate four factors, two drivers and two barriers, influencing blockchain adoption; perceived interoperability, perceived data quality, perceived lack of technological knowledge and perceived technological volatility. An extensive literature review has not revealed a prior study that has considered how the volatility of a technology influences organizational adoption decisions, opening up new research directions and expanding aspects of consideration for technology adoption. Further, a new empirically validated scale was developed to measure an organization's perception of a technology's volatility, allowing future researchers to accurately measure the construct. In addition, several critical blockchain technology development considerations were presented, to aid organizations with their own implementations. This section includes the industries developing blockchain and the specific use cases being implemented, cost and length factors for blockchain projects, future direction themes and a 10-year development timeline.

Overall, this research has contributed to furthering the adoption of blockchain technology and enriching the technological adoption literature. Organizations considering or engaged in blockchain development, blockchain consulting firms, and blockchain researchers now have a deeper understanding of the adoption phenomenon which can be used to further organizational adoption, development and implementation. With wider adoption, individuals, organizations can realize the benefits of blockchain technology resulting in an improved society. 
Appendices 
Appendix A - Interview Demographic Information

\begin{tabular}{|c|c|c|c|c|c|c|}
\hline No. & $\begin{array}{l}\text { Organization } \\
\text { Type/Size }\end{array}$ & Sector & Interviewee Position & $\begin{array}{l}\text { Establishment } \\
\text { Date }\end{array}$ & $\begin{array}{l}\text { Annual } \\
\text { Revenue } \\
\text { (Millions) } \\
\end{array}$ & $\begin{array}{l}\text { Number of } \\
\text { Employees }\end{array}$ \\
\hline 1 & $\begin{array}{l}\text { Large } \\
\text { Organization }\end{array}$ & $\begin{array}{l}\text { Public Services - } \\
\text { Innovation }\end{array}$ & $\begin{array}{l}\text { Technological Subject } \\
\text { Matter Expert and } \\
\text { Executive }\end{array}$ & 1916 & $\begin{array}{l}\text { Not-for } \\
\text { Profit }\end{array}$ & $>1000$ \\
\hline 2 & Start-up & Financial & $\begin{array}{l}\text { Technological Subject } \\
\text { Matter Expert }\end{array}$ & 2017 & $<1$ & $<50$ \\
\hline 3 & $\begin{array}{l}\text { Large } \\
\text { Organization }\end{array}$ & $\begin{array}{l}\text { Public Services - } \\
\text { Food Safety }\end{array}$ & $\begin{array}{l}\text { Technological Subject } \\
\text { Matter Expert }\end{array}$ & 1997 & $\begin{array}{l}\text { Not-for } \\
\text { Profit }\end{array}$ & $>1000$ \\
\hline 4 & Start-up & $\begin{array}{l}\text { Identity } \\
\text { Management and } \\
\text { Corporate Social } \\
\text { Responsibility }\end{array}$ & Executive & 2018 & $<1$ & $<50$ \\
\hline 5 & Start-up & Technology & $\begin{array}{l}\text { Technological Subject } \\
\text { Matter Expert and } \\
\text { Senior Management }\end{array}$ & 2018 & $<1$ & $<50$ \\
\hline 6 & Start-up & Technology & Executive & 2017 & $1-5$ & $<50$ \\
\hline 7 & $\begin{array}{l}\text { Small-to- } \\
\text { Medium } \\
\text { Organization }\end{array}$ & $\begin{array}{l}\text { Professional } \\
\text { Services }\end{array}$ & $\begin{array}{l}\text { Technological Subject } \\
\text { Matter Expert and } \\
\text { Executive }\end{array}$ & 2011 & $5-10$ & $<50$ \\
\hline 8 & $\begin{array}{l}\text { Large } \\
\text { Organization }\end{array}$ & Financial & Middle Management & 1867 & $>10$ & $>1000$ \\
\hline 9 & $\begin{array}{l}\text { Large } \\
\text { Organization }\end{array}$ & $\begin{array}{l}\text { Public Services - } \\
\text { Financial }\end{array}$ & $\begin{array}{l}\text { Technological Subject } \\
\text { Matter Expert and } \\
\text { Middle Management }\end{array}$ & 1867 & $\begin{array}{l}\text { Not-for } \\
\text { Profit }\end{array}$ & $>1000$ \\
\hline 10 & $\begin{array}{l}\text { Large } \\
\text { Organization }\end{array}$ & $\begin{array}{l}\text { Public Services - } \\
\text { Infrastructure }\end{array}$ & Executive & 2000 & $\begin{array}{l}\text { Not-for } \\
\text { Profit }\end{array}$ & $250-1000$ \\
\hline 11 & $\begin{array}{l}\text { Large } \\
\text { Organization }\end{array}$ & $\begin{array}{l}\text { Professional } \\
\text { Services }\end{array}$ & $\begin{array}{l}\text { Partner - Technology } \\
\text { Consulting }\end{array}$ & 1987 & $>10$ & $>1000$ \\
\hline 12 & $\begin{array}{l}\text { Large } \\
\text { Organization }\end{array}$ & $\begin{array}{l}\text { Public Services - } \\
\text { Information } \\
\text { Technology }\end{array}$ & $\begin{array}{l}\text { Technological Subject } \\
\text { Matter Expert }\end{array}$ & 2011 & $\begin{array}{l}\text { Not-for } \\
\text { Profit }\end{array}$ & $>1000$ \\
\hline 13 & Start-up & Technology & Executive & 2018 & $1-5$ & $50-250$ \\
\hline 14 & $\begin{array}{l}\text { Large } \\
\text { Organization }\end{array}$ & $\begin{array}{l}\text { Public Services - } \\
\text { Transportation }\end{array}$ & $\begin{array}{l}\text { Technological Subject } \\
\text { Matter Expert and } \\
\text { Executive }\end{array}$ & 1921 & $\begin{array}{l}\text { Not-for } \\
\text { Profit }\end{array}$ & $250-1000$ \\
\hline 15 & Start-up & $\begin{array}{l}\text { Professional } \\
\text { Services }\end{array}$ & $\begin{array}{l}\text { Technological Subject } \\
\text { Matter Expert and } \\
\text { Executive }\end{array}$ & 2019 & $<1$ & $<50$ \\
\hline 16 & $\begin{array}{l}\text { Large } \\
\text { Organization }\end{array}$ & $\begin{array}{l}\text { Public Services - } \\
\text { Information } \\
\text { Technology }\end{array}$ & $\begin{array}{l}\text { Technological Subject } \\
\text { Matter Expert and } \\
\text { Executive }\end{array}$ & 1834 & $\begin{array}{l}\text { Not-for } \\
\text { Profit }\end{array}$ & $250-1000$ \\
\hline 17 & $\begin{array}{l}\text { Large } \\
\text { Organization }\end{array}$ & $\begin{array}{l}\text { Public Services - } \\
\text { Innovation }\end{array}$ & $\begin{array}{l}\text { Technological Subject } \\
\text { Matter Expert }\end{array}$ & 1916 & $\begin{array}{l}\text { Not-for } \\
\text { Profit }\end{array}$ & $>1000$ \\
\hline 18 & $\begin{array}{l}\text { Large } \\
\text { Organization }\end{array}$ & $\begin{array}{l}\text { Public Services - } \\
\text { Transportation } \\
\text { and Logistics }\end{array}$ & $\begin{array}{l}\text { Technological Subject } \\
\text { Matter Expert }\end{array}$ & 1935 & $\begin{array}{l}\text { Not-for } \\
\text { Profit }\end{array}$ & $>1000$ \\
\hline 19 & $\begin{array}{l}\text { Small-to- } \\
\text { Medium } \\
\text { Organization }\end{array}$ & $\begin{array}{l}\text { Identity } \\
\text { Management }\end{array}$ & $\begin{array}{l}\text { Technological Subject } \\
\text { Matter Expert and } \\
\text { Executive }\end{array}$ & 2008 & $>10$ & $250-1000$ \\
\hline 20 & $\begin{array}{l}\text { Large } \\
\text { Organization }\end{array}$ & Financial & Executive & 1850 & $>10$ & $>1000$ \\
\hline
\end{tabular}




\begin{tabular}{|l|l|l|l|l|l|l|}
\hline No. & $\begin{array}{l}\text { Organization } \\
\text { Type/Size }\end{array}$ & Sector & Interviewee Position & $\begin{array}{l}\text { Establishment } \\
\text { Date }\end{array}$ & $\begin{array}{l}\text { Annual } \\
\text { Revenue } \\
\text { Millions) }\end{array}$ & $\begin{array}{l}\text { Number of } \\
\text { Employees }\end{array}$ \\
\hline $\mathbf{2 1}$ & Start-up & Technology & $\begin{array}{l}\text { Technological Subject } \\
\text { Matter Expert and } \\
\text { Executive }\end{array}$ & 2017 & $<1$ & $<50$ \\
\hline $\mathbf{2 2}$ & Start-up & Healthcare & Executive & 2017 & $<1$ & $<50$ \\
\hline $\mathbf{2 3}$ & Start-up & $\begin{array}{l}\text { Human } \\
\text { Resources }\end{array}$ & Executive & 2017 & $<1$ & $<50$ \\
\hline $\mathbf{2 4}$ & $\begin{array}{l}\text { Large } \\
\text { Organization }\end{array}$ & $\begin{array}{l}\text { Public Services - } \\
\text { Innovation }\end{array}$ & $\begin{array}{l}\text { Technological Subject } \\
\text { Matter Expert and } \\
\text { Executive }\end{array}$ & 1916 & $\begin{array}{l}\text { Not-for } \\
\text { Profit }\end{array}$ & $>1000$ \\
\hline $\mathbf{2 5}$ & Start-up & Academia & $\begin{array}{l}\text { Technological Subject } \\
\text { Matter Expert and } \\
\text { Executive }\end{array}$ & 2018 & $<1$ & $<50$ \\
\hline
\end{tabular}


Appendix B - Survey Demographic Information

\begin{tabular}{|l|l|}
\hline Demographic Category & Result \\
\hline Industry & Consulting/Professional Services - 9.7\% \\
& Education - 6.9\% \\
& Energy - 3.4\% \\
& Financial - 28.3\% \\
Government -12.4\% & Healthcare - 8.3\% \\
& Supply Chain - 10.3\% \\
& Technology - 19.3\% \\
& Telecommunications - 1.4\% \\
\hline Technology Status & Consumer - 30.3\% \\
& Consumer and Regulator - 1.4\% \\
& Provider - 46.9\% \\
& Provider and Consumer - 0.7\% \\
& Regulator - 20.7\% \\
\hline Organization Size/Type & Start-Up (<50) - 35.2\% \\
& Small-to-Medium $(50-999)-13.1 \%$ \\
& Large Organization $(>1000)-50.3 \%$ \\
& N/a - 1.4\% \\
\hline Organization & Oldest - 1800 \\
Establishment Date & Newest - 2019 \\
& Span (from oldest to newest) - 219 years \\
& Percentage Before 2000 - 48.97\% \\
& Percentage After 2000 - 51.03\% \\
\hline Organization Revenue & $<\$ 10,000-24.8 \%$ \\
& $\$ 10,000-100,000-7.6 \%$ \\
& $\$ 100,000-1,000,000-3.4 \%$ \\
& $>1,000,000-42.1 \%$ \\
& Non-for-Profit - 17.9\% \\
N/a - 4.1\% \\
\hline Build or Buy Technology & Build - 30.3\% \\
& Buy - 29\% \\
Combination - 40.7\% \\
\hline
\end{tabular}




\section{Appendix C - Organizational Blockchain Adoption Factors - Interview Results}

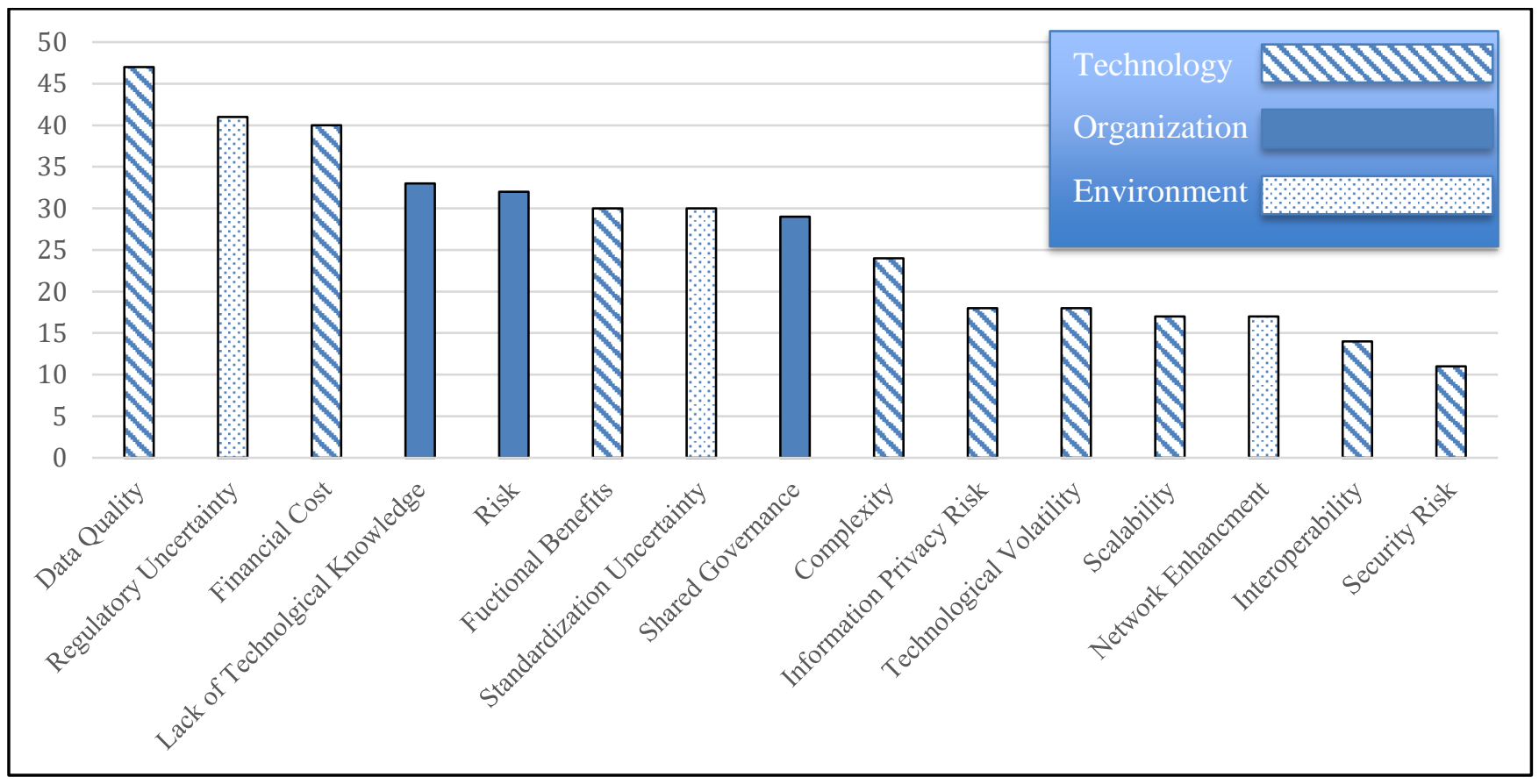


Appendix D - Interview Instrument

\section{Blockchain Technology Adoption}

This interview is part of research aiming at deepening our understanding of the adoption of blockchain technology and its influence on business performance. Data will be collected anonymously respecting your privacy and will be only used for research purposes. Your collaboration, by attending in the interview (that will take about 30 minutes), would be very precious for us.

What is your industry classification?

Healthcare $\square \quad$ Financial $\square \quad$ Supply chain $\square \quad$ Technology $\square$

Other. Please specify:

Would you consider your organization a technology:

Provider $\square \quad$ Consumer $\square \quad$ Regulator $\square$

What is your organization's size with respect to the number of employees?

$1-49 \square \quad 50-249 \square \quad 250-1000 \square \quad$ more than $1000 \square$

What is your position at your organization?

Technical/Subject Matter Expert

Middle Management (technical or non-technical)

Senior Management (technology department or non-technology)

Executive (technology portfolio, non-technology)

Other. Please specify:

What year was your organization established?

How long have you been in this organization?

What is your organization's annual revenue in 2018 (In Canadian Dollars)?

$<1$ million $\square \quad 1-5$ million $\square \quad 5-10$ million $\square>10$ million $\square \quad$ Non - for profit 
What is the size of your organization's investments/portfolio in blockchain technology (In Canadian Dollars)?

$<10$ thousand $\square \quad 10-100$ thousand $\square \quad 100$ thousand-1 million $\square \quad>1$ million $\square$

Does your organization build or buy technology? Build $\square \quad$ Buy $\square \quad$ Combination $\square$

1. Has your organization already implemented, in production, blockchain technology?

Provider - have your customers implemented a blockchain solution in production?

\section{If the answer is No:}

a. Does your organization have any plans in the next year to implement a blockchain solution?

Provider - do your customers have any plans in the next year to implement a blockchain solution?

b. Has your organization done any Proof-of-Concept $(\mathrm{PoC})$ implementations?

Provider - have your customers done any POC implementations?

c. Why did your organization decide not to implement the $\mathrm{PoC}$ in production?

Provider - why have your customers decided not to implement the $\mathrm{PoC}$ in production?

d. In your opinion, list the top five reasons for non-adoption of blockchain technology starting from the most important reason to the least important.

\section{If the answer is Yes:}

e. Why did your organization decide to adopt a blockchain based solution?

Provider - why do you believe your customers have adopted a blockchain based solution?

f. List the top five drivers of your organization's adoption from most important to least important?

Provider - List the top five drivers for your customer's adoption from most important to least important?

Other - In your opinion, what are the top five drivers for blockchain adoption?

g. What type(s) of blockchain solution(s) is your organization using? Public, private, consortium, or a hybrid and why did you choose this type?

Provider - What type(s) of blockchain solution(s) are your customers using? Public, private, consortium, or a hybrid and why did they choose this type? 
h. How would you describe your blockchain adoption and implementation process/strategy?

Provider - How would you describe your customer's blockchain adoption and implementation process/strategy?

i. What were the steps involved in implementing this emerging technology?

j. How long did the implementation take from inception to completion? e.g., test, dev, UAT, production?

k. Can you describe or justify the reasons that determined the length of the implementation?

1. What was the estimated cost of implementation?

m. Can you describe or justify the reasons that determined the cost of the implementation?

n. Is the blockchain solution that is implemented, an essential part of the business model of your firm? In other words, is it a critical component or a marginal one?

Provider - Is the blockchain solution implemented an essential part of the business model for your customers? In other words, is it a critical component or a marginal one?

o. How is your organization using blockchain technology?

Provider - How are your customers using blockchain technology?

Other - how are you seeing blockchain technology being used?

p. How can a blockchain solution comply with legislation given the regulation environment for your organization's industry?

q. How do you see blockchain standards being established?

r. Can you discuss in more detail the main disadvantages your organization feels it has suffered from adopting and implementing blockchain technology? Please list your top five reasons starting from the most important reason to the least important reason.

Provider - Can you discuss, if any, the main disadvantages your customers feel they have suffered from adoption / implementing blockchain technology? Please list your top five reasons starting from the most important reason to the least important reason. Other - What disadvantages do you possible from using blockchain technology?

2. What needs to change about blockchains to enable more implementations?

3. What must change from a business operating or technical perspective in order to enable more blockchain implementations? 
4. Is your industry ready for blockchain technology?

a. If not, what would it take for it to be ready?

Provider - Are your customers industries ready for blockchain technology?

a. If not, what would it take for it to be ready?

5. Where do you believe blockchain technology is headed?

b. In the next 5 years.

c. In the next 10 years.

6. Is there anything, in the context of blockchain adoption, you would like to add?

Length of Interview:

Interview Code:

Date of Interview 
Appendix E - Survey Instrument

\section{Blockchain Technology Adoption}

This survey is part of research aiming at deepening our understanding of the main barriers and drivers of the adoption of blockchain technology and its influence on business performance. Data will be collected anonymously respecting your privacy and will be only used for research purposes. Your collaboration, by filling in the questionnaire (that will take about 30 minutes), would be very precious for us.

\section{Part A}

What is your gender?

Male $\square \quad$ Female $\square \quad$ Other. Please specify

What is your industry classification?

Healthcare $\square \quad$ Financial $\square \quad$ Supply chain $\square \quad$ Energy $\square$

Other. Please specify:

Would you consider your organization a technology:

Provider $\square \quad$ Consumer $\square \quad$ Regulator $\square$

What is your organization's size with respect to the number of employees?
$1-49$
50-249
250- 1000
$>1000$

What is the size of your organization's investments/portfolio in blockchain technology (In Canadian Dollars)?

$>10$ thousand $\square \quad 10-100$ thousand $\square \quad 100$ thousand-1 million $\square \quad<1$ million $\square$

What is your position at your organization?

Technical/Subject Matter Expert

Middle Management (technical or non-technical)

Senior Management (technology department or non-technology)

Executive (technology portfolio, non-technology)

Other. Please specify

When year was your organization established? 
How long have you been in this organization?

\section{What is your organization's annual revenue in 2017 (In Canadian Dollars)?}

$<1$ million $\square \quad 1-5$ million $\square \quad 5-10$ million $\square \quad>10$ million $\square \quad$ Non-for profit $\square$

Does your organization currently use blockchain technology in production?

Yes $\square \quad$ No $\square$

Does your organization build or buy technology? Build $\square \quad$ Buy $\square$ Combination $\square$

\section{Part B}

\begin{tabular}{l} 
For each of the following statements please indicate the degree to which you agree or disagree \\
\hline 1
\end{tabular}

Firm Performance (FP)

FP1: In comparison with your major competitors over the past two years, your organization has more market share.(Removed)

FP2: In comparison with your major competitors over the past two years, your organization has a faster growth rate.

FP3: In comparison with your major competitors over the past two year, your organization has higher profitability.

FP4: In comparison with your major competitors over the past two years, your organization has become more efficient.

7-point Likert type scale (used)

$1=$ strongly disagree

\begin{tabular}{|l|l|l|l|l|l|}
\hline 2 & 3 & 4 & 5 & 6 & $7=$ strongly agree
\end{tabular}

Adapted/Adop ted or Inspired Adopted from: Rhee et al. $(2010)+1$ Adhoc Scale (Item 4)

\section{Perceived Lack Level of Technological Knowledge (PLTK)}

PLTK1: Our organization has little knowledge about how blockchain technology could be used within our organization.

PLTK2: Our organization would use blockchain technology sooner if we knew more about what it could do for our organization.(Removed)

PLTK3: We do not have the technical knowledge and skills to start using blockchain technology.

PLTK4: Our organization's technology decision makers do not fully understand blockchain technology.

7-point Likert type scale (used)

\begin{tabular}{|l|l|l|l|l|l|l|l}
\hline $1=$ strongly disagree & 2 & 3 & 4 & 5 & 6 & $7=$ strongly agree
\end{tabular}

Adapted/Adop ted or Inspired

Adapted from: Lee \& Shim (2007)

\section{Perceived Network Enhancement (PNE)}

PNE1: Blockchain technology can provide networking opportunities for our organization.

PNE2: Blockchain technology can create collaborative relationships for our organization.

PNE3: Blockchain technology can exploit new networks in our business environment.

PNE4: Blockchain technology can strengthen our organization's existing networks.

Adapted/Adop ted or Inspired Adapted from Forsman (2011) 


\section{7-point Likert type scale (used)}

$1=$ strongly disagree

2

3

4

5

6

$7=$ strongly agree

\section{Perceived Interoperability (PI)}

PI1: If we adopted blockchain technology, it would be compatible with our legacy systems.

PI2: If we adopted blockchain technology, it would be compatible with our legacy processes.

PI3: If we adopted blockchain technology, it would be compatible with our legacy databases.

7-point Likert type scale (used)

\begin{tabular}{|l|l|l|l|l|l|l|l}
\hline $1=$ strongly disagree & 2 & 3 & 4 & 5 & 6 & $7=$ strongly agree \\
\hline
\end{tabular}

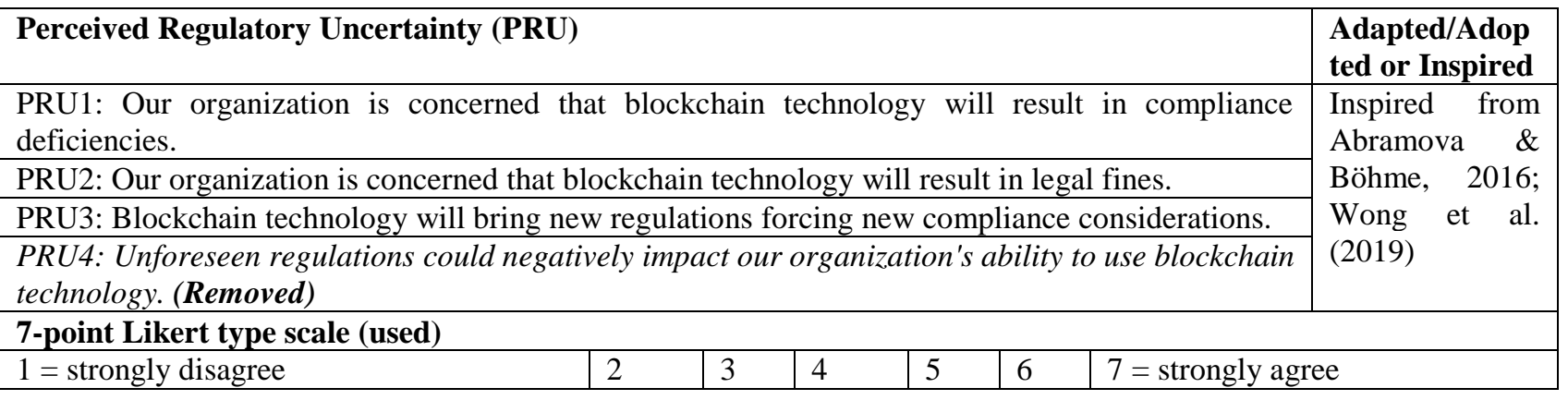

\section{Perceived Standardization Uncertainty (PSU)}

PSU1: Our organization is concerned blockchain technology standards are inconsistent across Blockchain platforms.

PSU2: Our organization is concerned blockchain technology standards are not stable.

PSU3: Our organization is concerned our existing (internal) standards are not compatible with external blockchain standards.

PSU4: Our organization is concerned blockchain technology has poorly established standards.

7-point Likert type scale (used)

\begin{tabular}{|l|l|l|l|l|l|l|}
\hline $1=$ strongly disagree & 2 & 3 & 4 & 5 & 6 & $7=$ strongly agree
\end{tabular}

Adapted/Adop ted or Inspired Inspired from Yang (2019)

\section{Perceived Technological Volatility (PTV)}

PTV1: Our organization finds it difficult to make meaningful comparisons between different Blockchains.

PTV2: Well established blockchains cannot be trusted to remain stable.

PTV3: Even the most established blockchains have had hard forks, which is problematic. (Removed)

PTV4: Blockchain technology is too immature for our organization.

7-point Likert type scale (used)

$1=$ strongly disagree

\begin{tabular}{|l|l|l|l|l|l|}
\hline 2 & 3 & 4 & 5 & 6 & $7=$ strongly agree
\end{tabular}

Adapted/Adop ted or Inspired Developed

\begin{tabular}{|l|}
\hline Perceived Data Quality (PDQ) \\
\hline $\begin{array}{l}\text { PDQ1: Our organization will benefit from blockchain technology's ability to reduce the risk of a } \\
\text { single point of failure. }\end{array}$ \\
\hline PDQ2: Our organization will benefit from blockchain technology's tamper evident data structure. \\
\hline $\begin{array}{l}\text { PDQ3: Our organization will benefit from blockchain technology's ability to provide a single version } \\
\text { of the truth. }\end{array}$ \\
\hline
\end{tabular}

Adapted/Adop ted or Inspired

Adapted from

DeLone \&

McLean (1992); 
PDQ4: Blockchain technology will increase the efficiency of our organization's ability to perform data reconciliation.

Aparicio et al.,

PDQ5: Blockchain technology's will increase our organization's data auditability.

7-point Likert type scale (used)

$1=$ strongly disagree

2

3

\begin{tabular}{|l|l|l|l}
4 & 5
\end{tabular}

\begin{tabular}{l|l}
6 & $7=$ strongly agree
\end{tabular}

Adapted/Adop

Behavioural Intention to Adopt Blockchain Technology (BI) ted or Inspired

BI1: Our organization will use blockchain technology on a regular basis in the future.

BI2: Our organization will use blockchain technology or a similar type of system for requests (transactions or other processing requirements).

BI3: Our organization plans to use blockchain technology in the next year.

Adopted from Venkatesh et al.

7-point Likert type scale (used)

$1=$ strongly disagree

2

3

\begin{tabular}{l|l}
4 & 5
\end{tabular}

\begin{tabular}{|l|l|l|}
5 & 6 & $7=$ strongly agree
\end{tabular} 
This article is $\odot$ Emerald Publishing and permission has been granted for this version to appear here

(https://www.emerald.com/insight/content/doi/10.1108/JBIM-05-2019-0236/full/html). Emerald does not grant permission for this article to be further copied/distributed or hosted elsewhere without the express permission from Emerald Group Publishing Limited.

Appendix F- Innovation Within Networks: Patent Strategies for Blockchain Technology

\section{Abstract}

Purpose - Understanding a technology's patent landscape, including patent strategies, helps organizations position themselves regarding their innovation and provides insight about a technology's future direction. This research aims to provide an overview of blockchain technology patenting trends and outlines an exploratory framework of patenting strategies for blockchain.

Design/Methodology/Approach - A total of 3,234 registered patents are analyzed to determine the geographical distribution and identify key actors patenting around the globe. In addition, an empirical study consisting of multiple case studies in the form of ten in-depth interviews with owners/managers of organizations based in North America was conducted to understand organizations' strategies for patenting blockchain technology.

Findings - Several novel insights regarding the strategies used for blockchain technology patenting. For example, the existence of strong anti-patent sentiment, which results in a lack of patenting by start-up organizations or has led to a form of open source patenting strategy. Larger organizations appear to be patenting defensively, and small-to-medium organizations are primarily patenting to defend their competitive advantage.

Practical Implications - Start-up organizations harbouring anti-patent sentiment should consider the open source patenting strategy to ensure that the collaborative innovation network can continue. They should also consider collaborating with other actors within the network to have a competitive position in the market.

Originality/Value - To the authors' knowledge, this paper is the first to conduct an empirical study with organizations currently using blockchain technology to understand patenting strategies used for blockchain

Keywords: Patenting Strategy, Blockchain Technology, Case Study, Patent Analysis, Clustering. Article Classification - Research paper. 
This article is $(\odot$ Emerald Publishing and permission has been granted for this version to appear here

(https://www.emerald.com/insight/content/doi/10.1108/JBIM-05-2019-0236/full/html). Emerald does not grant permission for this article to be further copied/distributed or hosted elsewhere without the express permission from Emerald Group Publishing Limited.

\section{Introduction}

Over recent years, blockchain technology has been an active area of research in both academia and industry. Blockchains are an innovative and disruptive technology with the potential to impact many industries including; healthcare (Griggs et al., 2018), real-estate (Mashatan \& Roberts, 2017), governance and citizen engagement (Hanifatunnisa \& Rahardjo, 2017), education (Sharples \& Domingue, 2016), economic transactions (Wang \& Kogan, 2018), logistics/supply chain (Gao et al., 2018) energy (Liang, Weller, Luo, Zhao, \& Dong, 2018) and, many more (Shen \& Pena-Mora, 2018; Casino et al., 2019). The National Institute of Standards and Technology (NIST) define blockchains as; tamper evident and resistant digitalized ledgers implemented in a distributed network, without a central repository or authority (Yaga et al., 2018).

The concept of a blockchain, although still immature, is not new. It was first conceptualized in 2008 by Satoshi Nakamoto in his seminal work titled; Bitcoin A Peer-to-Peer Electronic Cash System. Indeed, blockchain technology started with the cryptocurrency; Bitcoin. Nakamoto (2008) describes the Bitcoin blockchain as a peer-to-peer network for direct transactions using a distributed timestamp server that generates computational proofs of transactions in chronological order. In short, Nakamoto's Bitcoin blockchain is a method of transacting digital currency (cryptocurrencies) among a network of peers. The network can take several forms, comprising of individuals or B2B organizations. Overall, Nakamoto's Bitcoin combines several existing technological components such as, cryptography (digital signatures and hash functions), networks, data structures, a distributed consensus mechanism, and a programming language to create a new form of technology (Narayanan et al., 2016).

Overtime, Bitcoin gained significant value, although experiencing drastic fluctuations due to several factors (Sovbetov, 2018). The value fluctuations and what some would refer to as bubbles resulted in waves of public, organizational, and academic interest. Nakamoto's Bitcoin inspired others to consider the technology and over the next several years, numerous blockchains were developed; each providing a slightly different function. Alternative digital currencies, known as altcoins, were soon created to capture a portion of the cryptocurrency market (Cheah \& Fry, 2015). Two early and predominant altcoin examples are Ripple (Ripple, 2019) and Litecoin (Litecoin, 2019) launched in 2011 and 2012 respectively. In 2014, one of the most notable 
This article is $\odot$ Emerald Publishing and permission has been granted for this version to appear here

(https://www.emerald.com/insight/content/doi/10.1108/JBIM-05-2019-0236/full/html). Emerald does not grant permission for this article to be further copied/distributed or hosted elsewhere without the express permission from Emerald Group Publishing Limited.

blockchain developments was made; the Ethereum blockchain, described by (Buterin, 2018). Ethereum has a built in Turing-complete programming language which allows users to write applications and smart contracts (Buterin, 2018). Ethereum drastically expanded perceptions of the possible when using blockchain technology and sparked an entire new line of thinking. This new era of thought continues today, as does blockchain technology development.

Blockchain technology is an innovation with significant potential to affect Business-to Business (B2B) networks. Impacts can take three main forms; the creation of new B2B networks, the re-structuring of B2B networks, and the enhancement of existing B2B networks. Blockchains allow for peer-to-peer transactions to be conducted in a trustless B2B network (Lacity, 2018), which allows for the creation of new B2B networks. For example, Kang et al. (2017) describe how a consortium blockchain provides increased transaction security without the reliance on a trusted third party, enabling a new peer-to-peer network for electricity trading. With the ability to conduct direct peer-to-peer transactions, blockchains also allow for existing B2B networks to be restructured through the disintermediation of third-party intermediaries (Hughes et al., 2019). Dobrovnik, Herold, Fürst, \& Kummer, (2018) studied the impact of blockchain technology for logistics and noted third-party intermediaries are no longer needed to verify the transfer of ownership for goods within a supply chain. This radically changes the structure of existing supply chain networks. When it comes to B2B network enhancement blockchains are tamper-evident data structures, which creates immutable data (Narayanan et al., 2016; Hughes et al., 2019). This enhances the quality of data within B2B networks. In addition, blockchains can provide transparency, which facilitates increased trust among actors within networks. Finally, a blockchain can improve efficiency, lowers costs, and even provide automation capabilities (Narayanan et al., 2016; Hughes et al., 2019), all of which improve the functioning of B2B networks.

Today, blockchain technology is capturing the attention of managers and policy makers around the world. In 2016, the blockchain market was estimated to be worth 210.2 million and is predicted to be worth 2.31 billion by 2021 (Statista, 2016) and 7.59 billion by 2024 (Grand View Research, 2018). In addition, a recent $\mathrm{PwC}$ survey, of 600 executives geographically distributed around the globe shows that $84 \%$ of organizations are involved, in one way or another, with blockchain technology $(\mathrm{PwC}, 2018)$. With such high levels of interest, a large projected growth rate, and vast 
This article is $\odot$ Emerald Publishing and permission has been granted for this version to appear here

(https://www.emerald.com/insight/content/doi/10.1108/JBIM-05-2019-0236/full/html). Emerald does not grant permission for this article to be further copied/distributed or hosted elsewhere without the express permission from Emerald Group Publishing Limited.

impacts on business networks, there is a need to examine innovation trends for blockchain technology.

One proxy for innovation and economic activity is patent data (Wang, Zhao, Dang, Han, \& Shi, 2019; Acs, Anselin, \& Varga, 2002). A patent gives the inventors the right, for a limited period, to exclude others from using their invention, which has its boundaries defined by the written claims in the patent document (Somaya, 2012). However, over time, organizations began to conceptualize the patenting process as a strategic endeavor with the potential to achieve more than exclusion. This resulted in the development and use of patent strategies to be used in congruence with organization's business motivations (Somaya, 2012).

Technology-driven organizations need to find novel and innovative strategic approaches for emerging technologies based on their capabilities. Understanding the patent landscape, including patent strategies, can help organizations position themselves regarding their blockchain technology innovation and provide insight about the technology's future direction. As such, this research aims to provide an overview of blockchain technology patenting trends to understand the patenting landscape and outline an exploratory framework of blockchain technology patenting strategies.

The following section reviews the relevant literature regarding the use of patents as a tool for analysis and patent strategies. This is followed by an overview of the research methodology, analysis, and results. The paper concludes with a discussion of the results, managerial implications, theoretical implications, limitations, and future research.

\section{Literature Review}

The following literature review discusses how patents can be used as a tool for analysis and reviews previous literature on patents as a strategic tool for organizations.

\subsection{Patent as a Tool for Technology Analysis}

The original purpose of patenting was to foster innovation and economic development by preserving incentives to make and commercialize inventions (Somaya, 2012; Mazzoleni \& Nelson, 1998). As Macdonald (2004) puts it, the aim of a patent is to be a means to an end, with the end being further innovation. Patents encourage innovation, which, in turn, is supposed to produce 
This article is $\odot$ Emerald Publishing and permission has been granted for this version to appear here

(https://www.emerald.com/insight/content/doi/10.1108/JBIM-05-2019-0236/full/html). Emerald does not grant permission for this article to be further copied/distributed or hosted elsewhere without the express permission from Emerald Group Publishing Limited.

more innovation (Macdonald, 2004). Analyzing the historical data of patent applicants, citation information of patents, portfolio of assignees, and international patent classifications can develop research and development as well as market strategies (Jun, Park, \& Jang, 2012). In addition, a patent analysis can be used to compare the strategic industry positioning between countries. By analyzing patent counts or the number of applicants from different countries, researchers can quickly distinguish which countries are leading innovation in different areas of technology (Albino, Ardito, Dangelico, \& Petruzzelli, 2014). Similarly, organizations can use patent analyses to position themselves strategically in their industry. In the literature, different patent analysis approaches have been used to find the correlation between the value of patents, e.g., backward citation (Reitzig, 2004), forward citation (Fallah, Fishman, \& Reilly, 2009), word clustering (Dehghani \& Dangelico, 2018), and text mining (Tseng, Lin, \& Lin, 2007).

Word clustering is an approach for text-based data (Dehghani \& Dangelico, 2018) and categorizes technologies that share similar characteristics (Li, Zhou, Xue, \& Huang, 2015). Technological trends and associations can be discovered by analyzing these word clusters (Motohashi \& Tomozawa, 2016). This helps the decision-making process for technology analysts. In addition, Tseng et al. (2007) noted that text mining is useful for patent data and used text mining in their patent analysis. Indeed, there are many examples of using patent data to study the development trends of technological innovations (Jeong, Lee, Yoon, \& Phaal, 2015).

\subsection{Patent Strategy}

As the patenting process evolved and industries changed, managers began to realize that patents have strategic value. Somaya (2012) described a framework of patent strategies to organize the fragmented literature. One of the strategies he describes is the proprietary strategy which dictates patents be used as an isolation mechanism to shield an organization's competitive advantage from imitation. When using this strategy, the firm is attempting to obtain an exclusive position in the industry and make use of the technology themselves. Afuah (1999) discusses a similar strategy known as blocking. The idea is that if a firm has unique capabilities at each stage of their value chain, they can use patents strategically to keep competitors out of the market. Blind, Edler, Frietsch, \& Schmoch (2006) call this type of strategy an offensive blockade; patenting to prevent other firms from using the technology in the same or similar field. Rivette \& Kline (2000) 
This article is $\odot$ Emerald Publishing and permission has been granted for this version to appear here

(https://www.emerald.com/insight/content/doi/10.1108/JBIM-05-2019-0236/full/html). Emerald does not grant permission for this article to be further copied/distributed or hosted elsewhere without the express permission from Emerald Group Publishing Limited.

present two similar forms of proprietary strategies; clustering and bracketing. A clustering strategy is using multiple patents on a single product, which effectively builds a patent wall to keep competitors out. A bracketing strategy is when one does not have the patent on the invention, but patents everything around it to keep competitors from using it and out of the market. Pre-emptive patenting and patent fencing are two additional strategies geared toward keeping a market exclusive. Cohen, Nelson, \& Walsh (2000) describe patent fencing as a similar strategy to clustering; patenting around a core patent (patenting substitutes) to prevent competitors from entering the market. Pre-emptive patenting is defined as patenting substitute technologies before competitors, to prevent market entry (Ceccagnoli, 2009).

A second strategy from Somaya's (2012) framework is the defensive strategy where patents are filed to avoid a competitive disadvantage. This type is to defend against the patents of others (to avoid litigation, being forced to license, or being blocked) so the organization can operate freely. Blind et al. (2006) describe a similar strategy labeled a defensive blockade; when firms patent to prevent their own room to maneuver from being eroded from other's patents. Ziedonis (2004) describes an aggressive patenting strategy (filing many patents for a larger portfolio) as a mechanism to avoid being fenced in or held up (forced to pay license fees) by competitors. Hall and Ziedonis (2001) found that large-scale manufacturers are engaged in portfolio races to amass large portfolios of patents. These organizations are ramping up their patenting as a form of defense (e.g., to ensure the freedom to operate) and to assist in the winning of favorable terms in negotiations with other firms (Hall \& Ziedonis, 2001). Somaya (2012) discusses portfolios further, claiming that the defensive patent strategy can be reflected by the term portfolio patenting, which he describes as building large defensive portfolios of patents to avoid being held up (Somaya, 2012).

The third strategy from Somaya's (2012) framework is known as the leveraging strategy. A leveraging strategy is when an organization patents to pursue direct (licensing revenue) or indirect (greater power in negotiations) profit opportunities. Some organizations do not intend to produce the technology that underlies their patents but intend to use the patents strategically to make money from royalty payments or damage awards. These actors are referred to as patent sharks or trolls by Reitzig, Henkel, \& Heath (2007). Royalty stacking is a strategy like clustering, 
This article is $\odot$ Emerald Publishing and permission has been granted for this version to appear here

(https://www.emerald.com/insight/content/doi/10.1108/JBIM-05-2019-0236/full/html). Emerald does not grant permission for this article to be further copied/distributed or hosted elsewhere without the express permission from Emerald Group Publishing Limited.

in the sense that there are multiple patents on a single product, but the goal is not to exclude competitors, it is to force organizations to bear multiple royalty payments (Lemley \& Shapiro, 2007). Strategies are certainly employed for financial gain but receiving royalty payments is not the only strategic motivator. Similarly, small firms or start-up organizations may patent in hopes of signaling their technologically innovative capabilities to investors to secure funding (Veer \& Jell, 2012).

Although previous studies have identified several patent strategies (Somaya, 2012) for different products or industries, there is a lack of empirical studies identifying the patent strategies for blockchain technology. In fact, there is a general lack of knowledge about the blockchain innovation landscape and strategic motivation of blockchain technology patenting for different organizational environments, industry classifications, and business sizes. Second, much of the existing literature reviews patent strategies retrospectively; that is, they analyze what patent strategies have been used in the past. This research takes the stance of analyzing the application of patent strategies for an emerging technology in the early stages of maturity; making this research especially timely. Third, to the best of our knowledge, there has not been any patent analysis conducted for blockchain technology. Finally, this study is one of the first to employ multiple methods to analyze innovation trends for blockchain technology.

\section{Research Methodology}

The methodology used in this research is twofold. First, patent data is analyzed to determine the number of blockchain technology patents, how they are distributed geographically, and identify the key actors patenting around the globe. Second, the results of multiple case studies, consisting of in-depth interviews with owners/managers of organizations based in North America, are discussed to gain insight into organizations' strategies for patenting blockchain technology.

\subsection{Patent Analyses}

To analyze the development trends for blockchain patenting, data was collected from Clarivate Analytics. Since the first patent for blockchain technology was registered in 2012, the search for patents was between 2012 and 2018. The patent search ended on December $31^{\text {st }}, 2018$ giving us a 6-year span of data. To search for patents, different combinations of keywords were used that were 
This article is $(\odot$ Emerald Publishing and permission has been granted for this version to appear here

(https://www.emerald.com/insight/content/doi/10.1108/JBIM-05-2019-0236/full/html). Emerald does not grant permission for this article to be further copied/distributed or hosted elsewhere without the express permission from Emerald Group Publishing Limited.

most likely to be related to blockchain technology such as "Blockchain", "Cryptocurrency", "Bitcoin", "Distributed Ledger Technology", "Ethereum”, "Hyperledger”, "Smart Contract”. To choose the most relevant keywords, previous scientific literature was reviewed, in particular, the study by Miau \& Yang (2018). Keywords were searched in the patent document, specifically the patent title and abstract. The search process identified a total of 3,234 granted patents.

\subsection{Empirical Study}

To gain a deeper understanding of the strategic motivations behind the blockchain patenting, this research conducted an empirical study (Yin, 2011). An exploratory multiple case-study research design, in the form of semi-structured interviews, was chosen to collect the empirical data. This method was selected to enhance the external validity (Voss, 2010) and because multiple cases were available (Stake, 1995). The cases were selected to be a representative sample of organizations operating in the North American blockchain technology space. A review of our patent analysis (Section 4, Figure 2) revealed that North America holds over 25\% of the world's patents for blockchain technology, making it a hub for blockchain innovation and a reasonable choice for sample selection. The application of blockchain technology is not limited to a single industry or organization type, which stipulates the need for a heterogeneous sample. The selection of a heterogeneous sample is aligned with the theoretical replication approach (Yin, 1994) which aims to examine differing practices, in this case patenting, according to organization type and other characteristics such as industry.

Organizations were chosen to be aligned with the objectives of this study, to be representative of the North American population, and to maximize the amount of information obtained. In total, this research was able to conduct interviews with 16 organizations. However, several cases had no patents nor were involved with patenting in the blockchain space and were removed from the sample. This resulted in a final sample of 10 cases with organizations who had filed or were already granted blockchain patents. These 10 cases are representative of nine unique organizations and close to 200 blockchain patents that are either fully registered or filed. Table 1 outlines the details of each case. 
This article is () Emerald Publishing and permission has been granted for this version to appear here

(https://www.emerald.com/insight/content/doi/10.1108/JBIM-05-2019-0236/full/html). Emerald does not grant permission for this article to be further copied/distributed or hosted elsewhere without the express permission from Emerald Group Publishing Limited.

\begin{tabular}{|c|c|c|c|c|c|c|c|}
\hline No. & $\begin{array}{l}\text { Organization } \\
\text { Type }\end{array}$ & Industry & $\begin{array}{l}\text { Interviewee } \\
\text { Position }\end{array}$ & $\begin{array}{l}\text { Establishment } \\
\text { Date }\end{array}$ & $\begin{array}{l}\text { Annual } \\
\text { Revenue } \\
\text { (Millions) }\end{array}$ & $\begin{array}{l}\text { Number } \\
\text { of } \\
\text { Employees }\end{array}$ & $\begin{array}{l}\text { Number of } \\
\text { Blockchain } \\
\text { Patents } \\
\text { Registered } \\
\text { or Filed }\end{array}$ \\
\hline 1 & $\begin{array}{l}\text { Small - } \\
\text { Medium } \\
\text { Organization }\end{array}$ & $\begin{array}{l}\text { Technology } \\
\text { Identity } \\
\text { Management }\end{array}$ & $\begin{array}{l}\text { Technical } \\
\text { Subject } \\
\text { Matter } \\
\text { Expert and } \\
\text { Executive }\end{array}$ & 2008 & $>10$ & $50-249$ & 4 \\
\hline 2 & $\begin{array}{l}\text { Large } \\
\text { Organization }\end{array}$ & Financial & $\begin{array}{l}\text { Senior } \\
\text { Management } \\
\text { and } \\
\text { Executive }\end{array}$ & 1855 & $>10$ & $>1000$ & 11 \\
\hline 3 & Start-up & Financial & $\begin{array}{l}\text { Technical } \\
\text { Subject } \\
\text { Matter } \\
\text { Expert } \\
\end{array}$ & 2017 & $<1$ & $1-49$ & 35 \\
\hline 4 & Start-up & Technology & $\begin{array}{l}\text { Technical } \\
\text { Subject } \\
\text { Matter } \\
\text { Expert and } \\
\text { Executive } \\
\end{array}$ & 2017 & $<1$ & $1-49$ & 2 \\
\hline 5 & $\begin{array}{l}\text { Small - } \\
\text { Medium } \\
\text { Organization }\end{array}$ & Technology & $\begin{array}{l}\text { Partner } \\
\text { (Lawyer) }\end{array}$ & 1967 & $>10$ & $50-249$ & 30 \\
\hline 6 & Start-up & $\begin{array}{l}\text { Technology } \\
\text { Healthcare }\end{array}$ & Executive & 2017 & $<1$ & $1-49$ & 1 \\
\hline 7 & Start-up & Technology & $\begin{array}{l}\text { Technical } \\
\text { Subject } \\
\text { Matter } \\
\text { Expert and } \\
\text { Executive }\end{array}$ & 2018 & $<1$ & $1-49$ & 5 \\
\hline 8 & Start-up & $\begin{array}{l}\text { Technology } \\
\text { Human } \\
\text { Resources }\end{array}$ & Executive & 2017 & $<1$ & $1-49$ & 2 \\
\hline 9 & $\begin{array}{l}\text { Small - } \\
\text { Medium } \\
\text { Organization }\end{array}$ & Technology & $\begin{array}{l}\text { Partner } \\
\text { (Lawyer) }\end{array}$ & 2011 & $1-5$ & $1-49$ & 100 \\
\hline 10 & $\begin{array}{l}\text { Large } \\
\text { Organization }\end{array}$ & Financial & Executive & 1855 & $>10$ & $>1000$ & 11 \\
\hline
\end{tabular}

Table 1 -Interviewee Details

\section{Analysis and Results}

The following section presents the results of the patent analysis and empirical study. It includes results from the descriptive analytics, cluster analysis and cross-case analysis.

\subsection{Descriptive Analysis}


This article is $\odot$ Emerald Publishing and permission has been granted for this version to appear here

(https://www.emerald.com/insight/content/doi/10.1108/JBIM-05-2019-0236/full/html). Emerald does not grant permission for this article to be further copied/distributed or hosted elsewhere without the express permission from Emerald Group Publishing Limited.

Figure 1 illustrates the number of patents per year from 2012-2018. The graph illustrates an exponential increase in the number of patent registration for blockchain technology over the 6 years. In the period between 2012-2016, patent applications were conservative with less than 500 filings. In contrast, the period between 2017 and 2018 shows a very sharp rise in the number of blockchain patent applications with 2,388 (74\%) recorded by the end of 2018. Having $74 \%$ of the total blockchain patents filed between 2017 and 2018 shows this technology is beginning to gain significant interest and patents are just starting to amass.

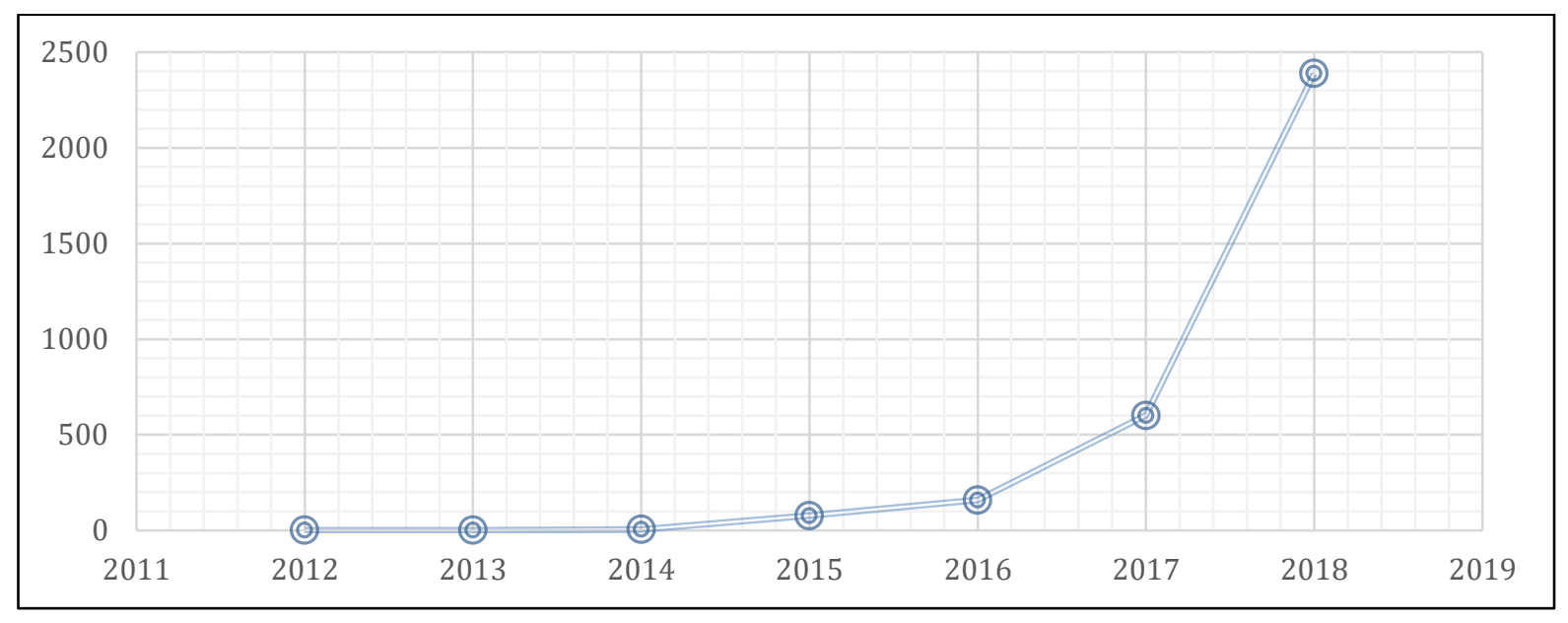

Figure 1 - Distribution of Patent Filings from 2012-2018

The geographic distribution of patents for blockchain technology is reported in Figure 2. China is the dominant country, contributing to $34 \%$ of patent registration and the United States is in second place with $25 \%$ of the share of the world's patents for blockchain technology. What is interesting is that two recent studies, one which analyzed patent data for the Internet-of-Things (IoT) (Ardito, D'Adda, \& Petruzzelli, 2018) and the other patent data for smart wearable technologies (Dehghani and Dangelico, 2018; Dehghani and Dangelico, 2017), found a similar distribution of registered patents. This speaks to a trend that emerging technologies seem to be patented most frequently in either Asia or North America. 
This article is ( $)$ Emerald Publishing and permission has been granted for this version to appear here (https://www.emerald.com/insight/content/doi/10.1108/JBIM-05-2019-0236/full/html). Emerald does not grant permission for this article to be further copied/distributed or hosted elsewhere without the express permission from Emerald Group Publishing Limited.

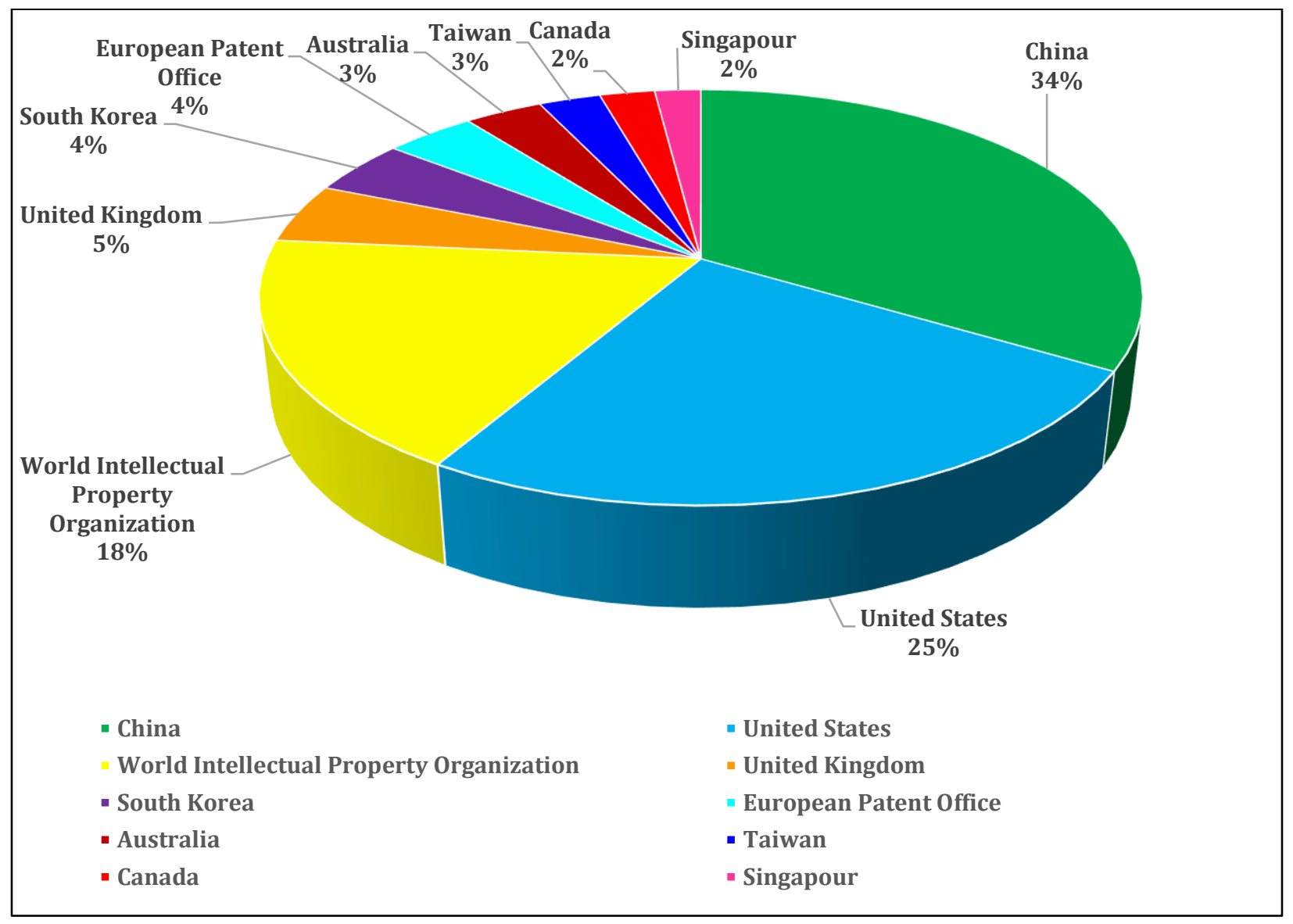

Figure 2 - The Geographic Distribution of Patents Registered

Figure 3 lists the top organizations in terms of number of registered patents for blockchain technology. According to the data, there are two leading organizations, Nchain Holding Ltd with 303 patents and MasterCard Inc. with 151. Similarly, IBM has a leading assignee with 141 patents, which places them in third position. The data shows that large technology providers, financial organizations, and blockchain start-ups are the predominant blockchain patentors. One consulting firm and one electronic-commerce provider were also in the top 10. 
This article is $\odot$ Emerald Publishing and permission has been granted for this version to appear here

(https://www.emerald.com/insight/content/doi/10.1108/JBIM-05-2019-0236/full/html). Emerald does not grant permission for this article to be further copied/distributed or hosted elsewhere without the express permission from Emerald Group Publishing Limited.

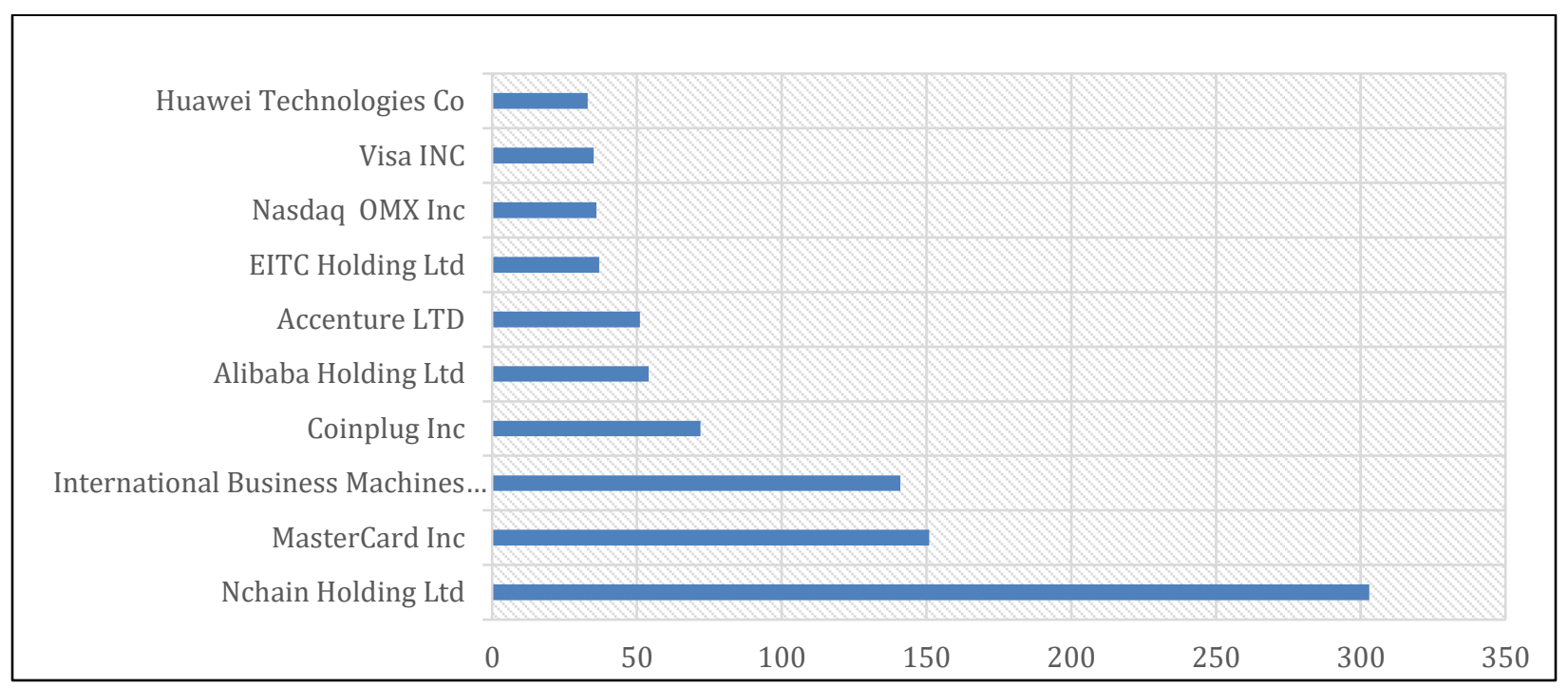

Figure 3 - Top 10 Organizations in Terms of Number of Registered Patents

\subsection{Clustering}

VOSviewer software (Waltman, Van Eck, \& Noyons, 2010) was used to construct and visualize patents keyword networks, since it has already been validated in previous technological studies (Leydesdorff, 2015). Text-mining techniques were employed first to transform the raw data into a structured data set using document parsing and term extraction methods. Titles and abstract descriptions of all patents were chosen to search for and build comprehensive clustering results. In total, 64,711 terms were recognized, with 5068 meeting the threshold based on the software's calculation. Then, clustering was employed to identify words with similar characteristics enabling us to highlight patent trends for blockchain technology. The keyword co-occurrence network is shaped when the keywords become visible in the published patents and co-appear, forming a link to the related blockchain patents.

Figure 4 illustrates the most frequent word stems and most associated word-stem pairs. Each word stem reflects a specific theme from the text. If a word stem, recognized with a given theme, had a high frequency with its associated word stem, the more important the theme. 
This article is $(\odot$ Emerald Publishing and permission has been granted for this version to appear here (https://www.emerald.com/insight/content/doi/10.1108/JBIM-05-2019-0236/full/html). Emerald does not grant permission for this article to be further copied/distributed or hosted elsewhere without the express permission from Emerald Group Publishing Limited.

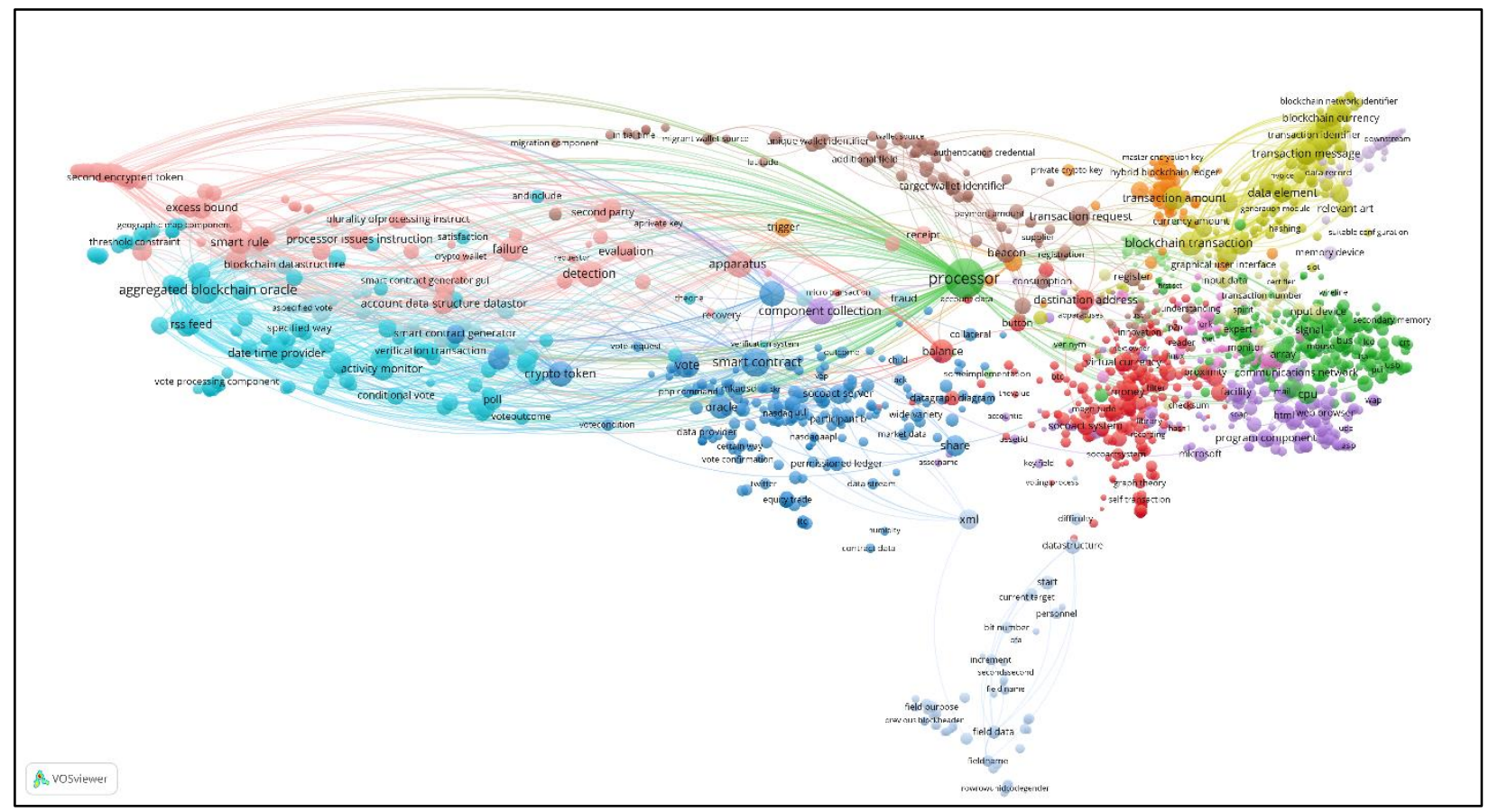

Figure 4 - Six Main Word Clusters

The interpretation of the results based on the high frequency words in each cluster and their relevancy score to other words within the network is provided in Table 2. Two researchers provided interpretations of the clusters independently and found very similar findings. Any differences were reconciled, producing synthesized results. In addition, a blockchain expert verified the interpretations, enhancing the validity further.

\begin{tabular}{|l|l|l|}
\hline Cluster & Cluster Key Terms & Interpretation \\
\hline 1 & $\begin{array}{l}\text { Processor } \\
\text { CPU } \\
\text { Signal } \\
\text { Micro Trusted Network } \\
\text { Secondary Memory } \\
\text { Peripheral Device } \\
\text { Network Interface } \\
\text { Input device }\end{array}$ & $\begin{array}{l}\text { This Cluster shows several patents focused on } \\
\text { optimizing the connection between devices and a } \\
\text { blockchain network. Several terms indicate patenting on } \\
\text { a form of mining rig or mining network. }\end{array}$ \\
\hline 2 & $\begin{array}{l}\text { Virtual Currency } \\
\text { Money }\end{array}$ & \\
\hline
\end{tabular}


This article is (C) Emerald Publishing and permission has been granted for this version to appear here

(https://www.emerald.com/insight/content/doi/10.1108/JBIM-05-2019-0236/full/html). Emerald does not grant permission for this article to be further copied/distributed or hosted elsewhere without the express permission from Emerald Group Publishing Limited.

\begin{tabular}{|c|c|c|}
\hline Cluster & Cluster Key Terms & Interpretation \\
\hline & $\begin{array}{l}\text { Socoact System } \\
\text { NFC (Near-Field Communication) } \\
\text { Destination Address } \\
\text { Self-Transaction } \\
\text { Graph Theory } \\
\text { Blockchain Recording } \\
\text { Bluetooth }\end{array}$ & $\begin{array}{l}\text { This Cluster signifies a system, which operates with } \\
\text { transactions as votes. This cluster may also indicate a } \\
\text { simplified method of conducting financial transactions } \\
\text { with a cellular device. } \\
\text { The terms signify that users of this system conduct } \\
\text { transactions or cast votes by tapping their phone on or } \\
\text { by creating a Bluetooth connection with a receiving } \\
\text { device. }\end{array}$ \\
\hline 3 & $\begin{array}{l}\text { Smart Contract } \\
\text { Crypto Token } \\
\text { Vote } \\
\text { Twitter } \\
\text { Permissioned Ledger Share } \\
\text { Electronic Wallet } \\
\text { Socoact Server } \\
\text { Oracle } \\
\text { Vote Confirmation } \\
\text { Participants }\end{array}$ & $\begin{array}{l}\text { This Cluster is indicative of a voting system. This voting } \\
\text { system includes access management components. } \\
\text { With terms like 'permissioned ledger share', it appears } \\
\text { this voting system can segregate users. For example, } \\
\text { with a voting system it would make sense to analyze } \\
\text { votes based on state or province. It would also make } \\
\text { sense to have the voting system permissioned, as only } \\
\text { certain individuals can vote for a given election. }\end{array}$ \\
\hline 4 & $\begin{array}{l}\text { Aggregated Blockchain } \\
\text { Vote Processing Component } \\
\text { Conditional Vote } \\
\text { Poll } \\
\text { Vote Outcome } \\
\text { Data Time Provider } \\
\text { Verification Transaction }\end{array}$ & $\begin{array}{l}\text { This Cluster indicates a voting system. The key terms } \\
\text { seem to be variable names for a voting system. The key } \\
\text { terms also imply the possibility of integrating multiple } \\
\text { blockchains into one combined chain and ensuring one } \\
\text { vote per person. }\end{array}$ \\
\hline 5 & $\begin{array}{l}\text { Beacon } \\
\text { Transaction request } \\
\text { Target wallet identifier } \\
\text { Authentication credential } \\
\text { Unique wallet identifier } \\
\text { Wallet source }\end{array}$ & $\begin{array}{l}\text { This Cluster is about a form of wallet backup or wallet } \\
\text { management use case. The terms also show the } \\
\text { possibility of efficiently connecting digital wallets. } \\
\text { Additionally, the terms also indicate a form of private- } \\
\text { permissioned blockchain. }\end{array}$ \\
\hline
\end{tabular}


This article is () Emerald Publishing and permission has been granted for this version to appear here

(https://www.emerald.com/insight/content/doi/10.1108/JBIM-05-2019-0236/full/html). Emerald does not grant permission for this article to be further copied/distributed or hosted elsewhere without the express permission from Emerald Group Publishing Limited.

\begin{tabular}{|l|l|l|}
\hline Cluster & Cluster Key Terms & Interpretation \\
\hline 6 & Mitigation component & \\
\hline $\begin{array}{l}\text { Pyper blockchain ledger } \\
\text { Data repository } \\
\text { Conventional blockchain ledger } \\
\text { Connected device } \\
\text { Master encryption key }\end{array}$ & $\begin{array}{l}\text { These terms speak to the basic components of a } \\
\text { blockchain. }\end{array}$ \\
& $\begin{array}{l}\text { The Hyperledger is an open source collaborative global } \\
\text { blockchain platform. }\end{array}$ \\
& $\begin{array}{l}\text { The term master encryption key infers confidentiality, } \\
\text { meaning this Cluster indicates information security for } \\
\text { blockchain technology. }\end{array}$ \\
\hline
\end{tabular}

Table 2 - Cluster Interpretations

\subsection{Cross-case Analysis}

To collect data for each case, one-to-one interviews were conducted. Consistent with Tomasin, Pereira, Borchardt, \& Sellitto (2013) methodology, a recording device and a transcription application (Otter.ai) were used. The transcribed data was compared to the audio record to ensure its accuracy; any discrepancies were resolved. Then, the transcribed interviews were analyzed to determine the strategic motivations behind each organization's patenting behaviour. The textual data from each interview was read multiple times to identify which of Somaya's (2012) patent strategy categories accurately reflect each case. As each case was read, key arguments reflecting the organization's strategic motivations were noted and added to the margins of the interview transcription. Two different researchers performed the above analysis independently and both found very similar results. This provides reproducibility reliability as described by Krippendorff (2004). Interviewee names and their respective organizations have been kept anonymous to preserve confidentiality, as some view this topic as highly sensitive. Yin (2017) described a compromise when anonymity must be maintained for case studies. Rather than presenting a series of case studies analyzing individual organizations, a cross-case analysis was performed. This allows for a synthesis of cases and comparisons across cases Yin (2017).

\section{3..1. Defensive Strategy}


This article is () Emerald Publishing and permission has been granted for this version to appear here

(https://www.emerald.com/insight/content/doi/10.1108/JBIM-05-2019-0236/full/html). Emerald does not grant permission for this article to be further copied/distributed or hosted elsewhere without the express permission from Emerald Group Publishing Limited.

The empirical study has revealed that several organizations are patenting blockchain technology in a defensive manner. According to Somaya (2012), a defensive strategy is when patents are filed to avoid a competitive disadvantage and defend against the patents of others. In short, an organization employing a defensive patenting strategy wants to maintain their freedom to operate (Somaya, 2012). For example, one blockchain patent expert (Case 3) from the financial industry mentioned:

"the financial institutions are filing a little more deliberately because what they're doing is they're looking at what are the vulnerable technologies or vulnerable businesses that blockchain could disrupt and they are filing head of that, right just as a purely defensive manner, just to make sure that they can still maintain some position within the space"

A patent expert highly experienced with blockchain patents (Case 5) provided further evidence for the use of a defensive strategy. When asked why organizations are filing blockchain technology patents, their response was:

"So, there are some companies, especially big financial institutions that I am sure have gotten into the space because they are worried that their competition is building a patent war chest and they don't want to be left holding the bag"

In other words, some organizations are patenting blockchain technology in fear of being out patented by competitors and excluded from the space. Overall, $40 \%$ of the cases mentioned a form of defensive strategy (see Table 3).

\section{3..2. Proprietary Strategy}

Based on the empirical results, the proprietary strategy was the most widely used among our sample. The proprietary strategy is used as an isolation mechanism to shield an organization's competitive advantage from imitation and obtain an exclusive position in the industry (Somaya, 2012). It is the strategy most aligned with the traditional reasoning for organizational patenting. This strategy is clearly articulated by several cases. For example, Case 8 stated:

"We're looking to file patents to be able to protect our market... Our strategy is offensive and competitive, where we're looking to block out competition and to use the patent" 
This article is $\odot$ Emerald Publishing and permission has been granted for this version to appear here

(https://www.emerald.com/insight/content/doi/10.1108/JBIM-05-2019-0236/full/html). Emerald does not grant permission for this article to be further copied/distributed or hosted elsewhere without the express permission from Emerald Group Publishing Limited.

A second example comes from Case 4:

"We filed the patent because this is our core IP. This is the value that we can provide to the wider economy and we'd like to be able to capture that value... What we do want to control is the ability of other players to fork our technology or to set up competing networks, which do not enable us to actually capture value"

Organizations interviewed clearly believe the space is highly competitive and in response, want to protect their innovations from competitors. In total, $80 \%$ of the cases claimed they were patenting blockchain technology using a form of the proprietary strategy.

\section{3..3. Leveraging Strategy}

Several organizations are employing a leveraging strategy. With the leveraging strategy, organizations are looking to pursue direct or indirect profit opportunities (Somaya, 2012). Direct profit opportunities could be in the form of licensing revenue or infringement lawsuits while indirect profit opportunities could be greater power when bargaining or gaining capital through investments (Somaya, 2012; Veer \& Jell, 2012). Case 6 declared they were filing their blockchain patent, in part, to capture the attention of investors:

"The reason, we would pursue either course is one it gives us competitive advantage, two it facilitates fundraising from investors and three it gives us competitive advantage... as part of the investor conversations, very quickly it will come up, what IP [intellectual property] do you have and how do you protect that IP. Personally, my preferred answer is being first to market and growing the market quickly. I value that more than patents, however many investors will place a priority on IP and IP protection within the company that they invest in"

This shows that Case 6 is aware investors are looking for an organization's IP and they plan to leverage their IP to capture their interest. Case 10 was also motivated to leverage their patents; however, they were not definitive regarding the precise nature of their leveraging.

"The whole intent with filing a patent is to capture and crystallize our innovation insight, so that we create a patent currency, how we choose to use that patent currency in the future, patents last 
This article is $\odot$ Emerald Publishing and permission has been granted for this version to appear here

(https://www.emerald.com/insight/content/doi/10.1108/JBIM-05-2019-0236/full/html). Emerald does not grant permission for this article to be further copied/distributed or hosted elsewhere without the express permission from Emerald Group Publishing Limited.

20 years, I don't know right now, there's no intent of that. But 10 years from now, there might

$$
\text { be" }
$$

Indeed, the empirical study showed that leveraging patents is a popular strategy among North American organizations. Altogether, $60 \%$ of the cases cited a form of leveraging strategy. Table 3 summarizes the cases.

\begin{tabular}{|c|c|c|c|c|c|c|c|c|c|}
\hline Num & $\begin{array}{l}\text { Patent } \\
\text { Registered }\end{array}$ & $\begin{array}{l}\text { Position of } \\
\text { the } \\
\text { Organization } \\
\text { in } \\
\text { Blockchain } \\
\text { Technology }\end{array}$ & $\begin{array}{l}\text { Time } \\
\text { to } \\
\text { Patent } \\
\text { (Years) }\end{array}$ & $\begin{array}{l}\text { Time } \\
\text { to } \\
\text { Patent }\end{array}$ & $\begin{array}{l}\text { Recruiting } \\
\text { Inventors }\end{array}$ & $\begin{array}{l}\text { External } \\
\text { collaboration }\end{array}$ & $\begin{array}{l}\text { External } \\
\text { /Competitive } \\
\text { Pressure }\end{array}$ & $\begin{array}{l}\text { Patent } \\
\text { Strategy }\end{array}$ & $\begin{array}{l}\text { Organization's } \\
\text { Patent } \\
\text { Barriers or } \\
\text { Concerns }\end{array}$ \\
\hline 1 & Yes & Strong & 3 & $\begin{array}{l}3 \\
\text { Years }\end{array}$ & No & Yes & Yes & Proprietary & $\begin{array}{l}\text { Patent Search. } \\
\text { Patent } \\
\text { Infringement. } \\
\text { Existing } \\
\text { Patents. } \\
\text { Licensing } \\
\text { Rights. }\end{array}$ \\
\hline 2 & Yes & Strong & 2 & $\begin{array}{l}2 \\
\text { Years }\end{array}$ & Yes & Yes & Yes & $\begin{array}{l}\text { Defensive } \\
\text { and } \\
\text { Proprietary }\end{array}$ & $\begin{array}{l}\text { Industry's } \\
\text { Patent Trolls. }\end{array}$ \\
\hline 3 & Yes & Strong & 2.5 & $\begin{array}{l}2.5 \\
\text { Years }\end{array}$ & N/a & No & Yes & $\begin{array}{l}\text { Leveraging } \\
\text { and } \\
\text { Defensive }\end{array}$ & $\begin{array}{l}\text { Market } \\
\text { Immaturity. } \\
\text { Existing } \\
\text { Patents. } \\
\text { Licensing } \\
\text { Rights. } \\
\end{array}$ \\
\hline 4 & Yes & Moderate & N/a & N/a & Yes & Yes & Yes & $\begin{array}{l}\text { Proprietary } \\
\text { and } \\
\text { Leveraging }\end{array}$ & Filing Costs. \\
\hline 5 & No & Moderate & N/a & N/a & N/a & No & Yes & $\begin{array}{l}\text { Proprietary, } \\
\text { Leveraging } \\
\text { and } \\
\text { Defensive }\end{array}$ & $\begin{array}{l}\text { Existing } \\
\text { Patents. } \\
\text { Licensing } \\
\text { Rights. } \\
\text { Rigorous } \\
\text { Examination } \\
\text { Process. } \\
\end{array}$ \\
\hline 6 & Yes & Moderate & N/a & N/a & Yes & Yes & Yes & $\begin{array}{l}\text { Proprietary } \\
\text { and } \\
\text { Leveraging }\end{array}$ & $\begin{array}{l}\text { Patent Search } \\
\text { Availability. } \\
\text { Existing } \\
\text { Patents. } \\
\text { Licensing } \\
\text { Rights. }\end{array}$ \\
\hline 7 & Yes & Strong & 2 & $\begin{array}{l}2 \\
\text { Years }\end{array}$ & Yes & No & Yes & Proprietary & $\begin{array}{l}\text { Public } \\
\text { Disclosure. }\end{array}$ \\
\hline 8 & Yes & Moderate & 1.5 & $\begin{array}{l}1.5 \\
\text { Years }\end{array}$ & Yes & No & Yes & Proprietary & $\begin{array}{l}\text { Existing } \\
\text { Patents. }\end{array}$ \\
\hline
\end{tabular}


This article is $(\odot$ Emerald Publishing and permission has been granted for this version to appear here

(https://www.emerald.com/insight/content/doi/10.1108/JBIM-05-2019-0236/full/html). Emerald does not grant permission for this article to be further copied/distributed or hosted elsewhere without the express permission from Emerald Group Publishing Limited.

\begin{tabular}{|l|l|l|l|l|l|l|l|l|l|}
\hline Num & $\begin{array}{l}\text { Patent } \\
\text { Registered }\end{array}$ & $\begin{array}{l}\text { Position of } \\
\text { the } \\
\text { Organization } \\
\text { in } \\
\text { Blockchain } \\
\text { Technology }\end{array}$ & $\begin{array}{l}\text { Time } \\
\text { to } \\
\text { Patent } \\
\text { (Years) }\end{array}$ & $\begin{array}{l}\text { Time } \\
\text { to } \\
\text { Patent }\end{array}$ & $\begin{array}{l}\text { Recruiting } \\
\text { Inventors }\end{array}$ & $\begin{array}{l}\text { External } \\
\text { collaboration }\end{array}$ & $\begin{array}{l}\text { External } \\
\text { /Competitive } \\
\text { Pressure }\end{array}$ & $\begin{array}{l}\text { Patent } \\
\text { Strategy }\end{array}$ & $\begin{array}{l}\text { Organization's } \\
\text { Patent } \\
\text { Barriers or } \\
\text { Concerns }\end{array}$ \\
\hline 9 & No & Moderate & 2 & $\begin{array}{l}2 \\
\text { Years }\end{array}$ & N/a & Yes & Yes & $\begin{array}{l}\text { Licensing } \\
\text { Rights. } \\
\text { Public } \\
\text { Disclosure. }\end{array}$ \\
\hline 10 & Yes & Strong & 3 & $\begin{array}{l}3 \\
\text { Years }\end{array}$ & No & Yes & Yes & $\begin{array}{l}\text { Drafting of } \\
\text { Blockchain } \\
\text { Patents. }\end{array}$ \\
\hline
\end{tabular}

Table 3 - Patent Strategy Summary

\section{Discussion}

This research has revealed two main points of discussion. The first revolves around the results of the cluster analysis and the second is regarding the empirical study.

\subsection{Cluster Discussion}

The six clusters show that blockchain patenting is occurring on three main verticals; the core components of a blockchain, blockchain technology use cases (voting and/or transaction system), and blockchain technology improvements (wallet management and confidentiality). Cluster 6 indicates patenting on the core components of a blockchain. This cluster shows some entities (individuals or organizations) are patenting their novel orchestrations of a blockchain solution. This could present a challenge for blockchain technology, as future innovations may be stifled by these patents. Individuals or organizations holding these patents could attempt to prevent others from using the needed orchestrations, use cases, or components and control the development of the technology. However, blockchain technology is still immature and likely to change, making these patents less powerful than the holding organizations believe them to be.

The other two verticals, patents on use cases and improvements, show that innovation is taking place that can push the development of blockchain technology forwards. Clusters 2 - 4 show that innovators are working toward a blockchain based voting system or a simplified method of conducting blockchain based transactions. Either of these use cases, if implemented properly, should provide enhanced validity for blockchain technology and push both its development and adoption. Having a successful use case sets a positive example for consumers and has the potential 
This article is () Emerald Publishing and permission has been granted for this version to appear here

(https://www.emerald.com/insight/content/doi/10.1108/JBIM-05-2019-0236/full/html). Emerald does not grant permission for this article to be further copied/distributed or hosted elsewhere without the express permission from Emerald Group Publishing Limited.

to increase interest. The transparent and immutable nature of blockchain technology can have positive implications on consumer confidence/trust in the voting process. In addition, simplifying a blockchain based transaction system can make the technology available to a wider audience. Clusters 1 and 5 signify that patenting activity is also taking place on specific blockchain improvements. For example, Cluster 5 speaks to a wallet management or wallet back up use case. Innovation in this area makes blockchain technology more secure and user-friendly, facilitating increased trust and allowing the technology to be used by a wider network of people. In addition, the more secure and trustworthy blockchain technology is perceived, the more likely to be used by organizations to strengthen their B2B networks.

One note is that whether these verticals are a challenge or benefit to blockchain technology depends on how specific the patents were written and the strategic orientation of the organization. Broad patents would make it difficult for future entities to innovate and potentially force these entities into licensing agreements. Narrow patents should prove to be less of a challenge, as blockchain technology is immature, and innovation can occur around them. In either case, an organization may choose to allow others to use the patent, facilitating an open source environment, or they may lock it down for themselves.

In sum, the results of our cluster analysis show that positive innovation is taking place for blockchain technology, however this depends on the specifics of the patent and how it is used.

\subsection{Empirical Discussion}

The empirical study has revealed several novel insights about the strategic motivations of North American organizations patenting blockchain technology. The results show organizations are using all three-core patent strategies. This demonstrates no single strategy is dominating blockchain patenting. The proprietary strategy was the most predominant; being mentioned in $80 \%$ of the cases. Organizations perceive the blockchain technology space to be highly competitive, as all 10 cases indicated they feel time pressure to be the first to obtain the patent due to external pressure (Table 3, Column 7). As a reaction, these organizations are making use of the proprietary strategy to defend their competitive advantage and keep competitors at bay. It appears as if the proprietary strategy is a base strategy to which others can be added. The leveraging strategy is the second most common with $60 \%$ of the cases using it and is followed closely by the defensive strategy used in $40 \%$ of the cases. 
This article is $(\odot$ Emerald Publishing and permission has been granted for this version to appear here

(https://www.emerald.com/insight/content/doi/10.1108/JBIM-05-2019-0236/full/html). Emerald does not grant permission for this article to be further copied/distributed or hosted elsewhere without the express permission from Emerald Group Publishing Limited.

When it comes to strategy selection, most organizations were using more than one patenting strategy, implying that when patenting blockchain technology the strategies are not mutually exclusive. However, further analysis shows that these organizations have a dominating strategy and secondary strategy. For example, Case 4 was patenting primarily to shield their competitive advantage (proprietary strategy), but had a secondary motivation to capture the attention of investors (leveraging).

Organizations' strategy selection also differed based on their size/level of development. Large financial institutions are using all three types of strategies, but were primarily using the defensive or leveraging strategy. Perhaps they perceived blockchain technology to be too immature for use in production but instead of standing idle, they have decided to patent defensively to ensure they cannot be kept out of the market. Alternatively, these large financial organizations appear to be patenting the technology for future leverage in negotiations or licensing agreements. On the other hand, small start-up organizations are primarily using the proprietary or leveraging strategies. This suggests they are motivated to grow their organizations by keeping competitors from imitating their blockchain solutions and if possible, leveraging their patents to attract the interest of investors. Small-to-medium organizations used a variety of strategies, but primarily employed the proprietary strategy. They are motivated to defend their competitive advantage and prevent imitation.

\subsection{Open Source Patenting}

One particularly intriguing insight gleamed from the empirical study was the presence of anti-patent sentiment. Several start-up organizations interviewed explained that innovation for blockchain technology should be conducted in an open source network and in a collaborative manner. These organizations feel that patenting, in the traditional sense of keeping the patented technology exclusive, is a hindrance on blockchain's development. As a result, some have decided not to patent ${ }^{1}$. However, the results of our empirical study show that experts in the field highly recommended these organizations patent their novel blockchain solutions. If they want to keep the open source network alive, they should patent their solutions and allow others to use them freely. Without filing the patent in an open source network, a competitor can start filing ahead within the technology stack and stop the open innovation. Filing the patent and making it open source can

\footnotetext{
${ }^{1}$ These were the cases removed from the final sample. They do not appear in Table 1 or 3.
} 
This article is $\odot$ Emerald Publishing and permission has been granted for this version to appear here

(https://www.emerald.com/insight/content/doi/10.1108/JBIM-05-2019-0236/full/html). Emerald does not grant permission for this article to be further copied/distributed or hosted elsewhere without the express permission from Emerald Group Publishing Limited.

ensure the technology grows. It also thwarts a separate entity from entering the space, patenting the technology, and preventing others from using it. In a sense, our results indicate a sub-patent strategy within the proprietary strategy; patent the technology but make it open for other actors within an open innovation network can use it. This way competitive organizations cannot start their own version of the innovation or patenting it themselves. Figure 6 shows where different sized organizations fall in terms of their patent strategy.

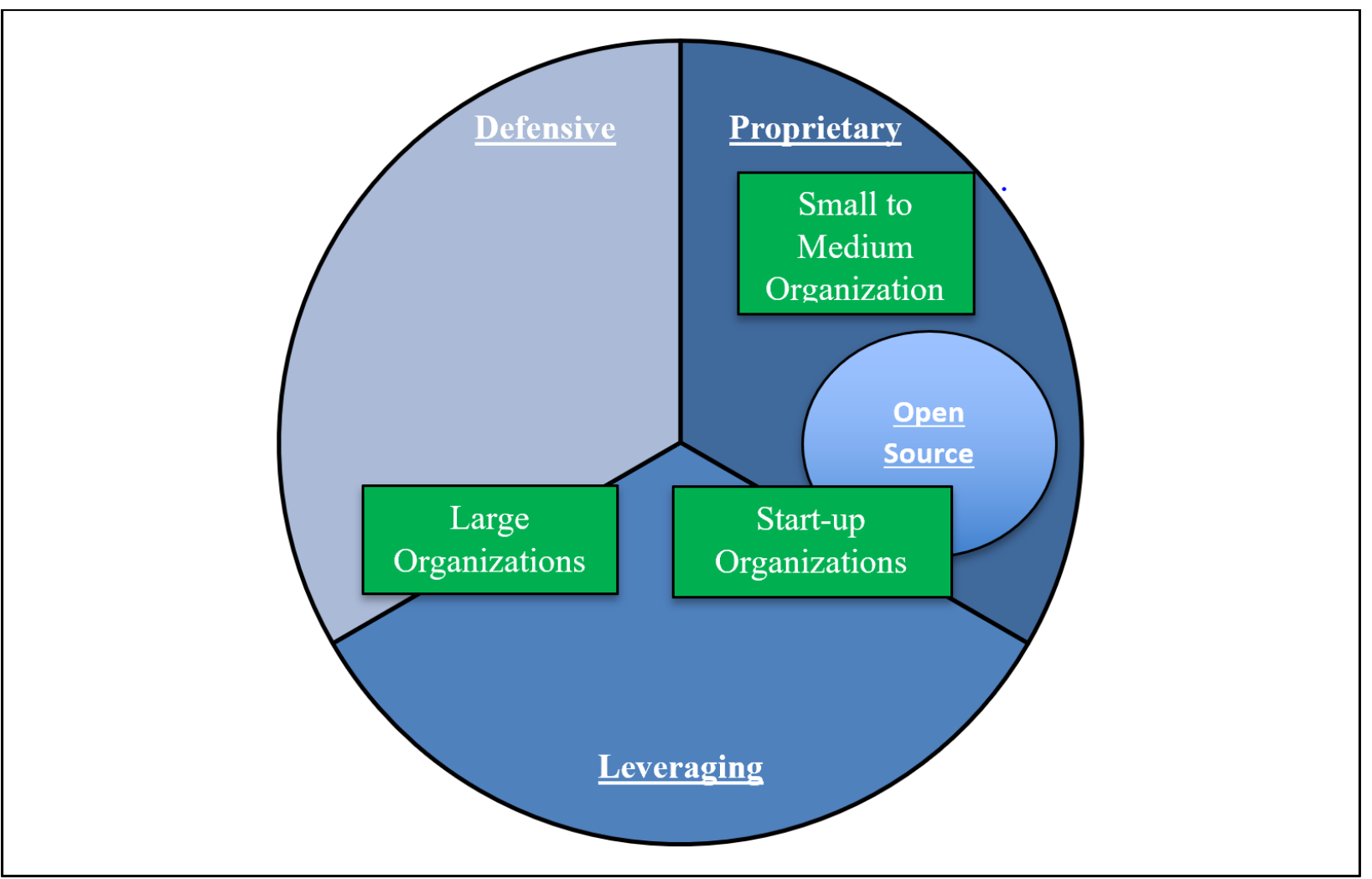

Figure 5 - Patent Strategies by Organizational Size

\subsection{Theoretical Implications}

Three theoretical contributions are made by this research. Most of the existing research about blockchain technology has focused on possible use cases, potential market disruption, technological limitations, and improvements to the technology (Hughes et al., 2019; Yli-Huumo et al., 2016). Analysis of innovation within the blockchain space, as indicated by patenting, has been severely neglected. To the best of our knowledge, this research represents the first patent analysis for blockchain technology aimed at understanding its innovation trends. In addition, this research is the first to conduct an empirical study in the form of multiple case studies, with 
This article is $\odot$ Emerald Publishing and permission has been granted for this version to appear here

(https://www.emerald.com/insight/content/doi/10.1108/JBIM-05-2019-0236/full/html). Emerald does not grant permission for this article to be further copied/distributed or hosted elsewhere without the express permission from Emerald Group Publishing Limited.

organizations currently using blockchain technology, to identify, analyze, and understand the patenting strategies used in the blockchain space. Several novel insights regarding the strategies used for blockchain technology patenting have been discovered and discussed. Finally, the empirical analysis has revealed that within the blockchain space, there exists strong anti-patent sentiment, which results in the lack of patenting by start-up organizations. However, this antipatent sentiment has led to, in some cases, a form of open source patenting, whereby an organization patents the technology, but makes it available for other innovators to use. This has the potential to extend Somaya's (2012) framework to include a sub-strategy within the proprietary category, showing new patenting motivations.

\subsection{Managerial Implications}

This research has several implications for managers operating within the blockchain technology space. A comprehensive picture of the blockchain patenting landscape has been presented. With an understanding of the current landscape, managers can strategically position their organization, regarding their blockchain patenting, within the space. Organizations of all types should realize that blockchain patenting has largely just begun, but is rapidly accelerating. As a result, managers of organizations currently operating within the blockchain space or organizations hoping to enter the space need to determine their strategic position now.

Organizations can also understand the geographical distribution of blockchain patenting and determine where gaps exist to enter the market. When it comes to patenting strategies, organizations should employ multiple strategies to fully reap the benefits of their patents, as the strategies are not mutually exclusive. Large financial organizations should realize that although their competitors may not be using blockchain technology currently, they might be building a large defensive blockchain patent portfolio. In response, these organizations need to start innovating within the blockchain space if they want to be able to use the technology in the future. These large organizations should also realize that blockchain technology does not have to be fully mature for them to begin innovating. A patent portfolio can be leveraged for several strategic reasons such as for better negotiations or to avoid costly patent infringement lawsuits (Somaya, 2012). Start-up organizations harboring anti-patent sentiment and refusing to patent, should consider the open source patenting strategy to ensure that collaborative and open source innovation network survives. They should also consider collaborative patenting by forming strategic alliances with other actors 
This article is $\odot$ Emerald Publishing and permission has been granted for this version to appear here

(https://www.emerald.com/insight/content/doi/10.1108/JBIM-05-2019-0236/full/html). Emerald does not grant permission for this article to be further copied/distributed or hosted elsewhere without the express permission from Emerald Group Publishing Limited.

within the network to cut the costs of filing. As blockchain technology is a significant enabler of B2B networks, organizations can patent in a collaborative manner when establishing shared solutions. Overall, knowing the current state of blockchain patenting has positive implications for managers to maneuver their current and future blockchain endeavors.

\subsection{Limitations and Future Research}

The main limitation of this research is surrounding the empirical study's sample. Although the number of cases is relatively low, considering the immaturity of blockchain technology, the sensitive nature of patenting, and the time frame of the study, this sample is all that could be obtained. The sample is also limited to North American organizations, which is considered one of the lead innovators for blockchain technology (See Figure 2). Future research should attempt to analyze blockchain patenting with a larger sample size representing organizations from a more diverse set of countries.

Another avenue for future research could be to analyze how the patenting landscape changes over time. Being that blockchain patenting has only recently become aggressive, the patent landscape is likely to change over the next few years. It would be interesting to conduct a longitudinal study, analyzing the development of the blockchain landscape over time.

The main goal of the empirical study in this paper was to identify which patent strategies were used. Future research should conduct an in-depth analysis of the factors contributing to the selection of an organization's patent strategy. This study discovered a difference based on organizational size and development level, however other factors may be involved. One final opportunity for future research could be to empirically validate our observation of a potentially new open source patenting strategy with a large sample of organizations. 
This article is $\odot$ Emerald Publishing and permission has been granted for this version to appear here

(https://www.emerald.com/insight/content/doi/10.1108/JBIM-05-2019-0236/full/html). Emerald does not grant permission for this article to be further copied/distributed or hosted elsewhere without the express permission from Emerald Group Publishing Limited.

Copyright Permission (Journal of Business \& Industrial Marketing, Emerald Publishing) 


\section{References}

Abramova, S. \& Böhme, R. (2016). Perceived benefit and risk as multidimensional determinants of bitcoin use: A quantitative exploratory study. Proceedings of the International conference on Information Systems (ICIS), Dublin, Ireland, December $11^{\text {th }}-14^{\text {th }}$, Association for Information Systems (AIS), Atlanta, GA, USA, pp. 1-20.

doi:10.17705/4icis.00001

Acs, Z. J., Anselin, L., \& Varga, A. (2002). Patents and innovation counts as measures of regional production of new knowledge. Research Policy, 31(7), 1069-1085. doi:10.1016/S0048-7333(01)00184-6

Afuah, A. (1999). Strategies to turn adversity into profits. Sloan Management Review, 40(2), 99109.. Retrieved from https://shop.sloanreview.mit.edu/store/search?q=Strategies+to+turn+adversity+into+profi ts

Ajzen, I. (1991). The theory of planned behavior. Organizational Behavior and Human Decision Processes, 50(2), 179-211. doi: 10.1016/0749-5978(91)90020-T

Albino, V., Ardito, L., Dangelico, R. M., \& Messeni Petruzzelli, A. (2014). Understanding the development trends of low-carbon energy technologies: A patent analysis. Applied Energy, 135, 836-854. doi:10.1016/j.apenergy.2014.08.012

Almarashdeh, I. (2018). An overview of technology evolution: Investigating the factors influencing non-Bitcoins users to adopt Bitcoins as online payment transaction method. Journal of Theoretical and Applied Information Technology, 96(13), 3984-3993. Retrieved from https://jatit.org/volumes/ninetysix13.php

Alomari, M., Woods, P., \& Sandhu, K. (2012). Predictors for e-government adoption in Jordan: Deployment of an empirical evaluation based on a citizen-centric approach. Information Technology \& People, 25(2), 207-234. doi: 10.1108/09593841211232712

Altaei, M., Al Barghuthi, N. B., Mahmoud, Q. H., Al Barghuthi, S., \& Said, H. (2019). Blockchain for UAE organizations: Insights from CIOs with opportunities and 
challenges. Proceedings of the 13th International Conference on Innovations in Information Technology (IIT), Al Ain, United Arab Emirates, November $18^{\text {th }}-19^{\text {th }}$, Institute of Electrical and Electronics Engineers (IEEE), New York, NY, USA, pp. 157162. doi:10.1109/INNOVATIONS.2018.8606033

Angelis, J., \& Ribeiro da Silva, E. (2019). Blockchain adoption: A value driver perspective. Business Horizons, 62(3), 307-314. doi:10.1016/j.bushor.2018.12.001

Aparicio, M., Oliveira, T., Bacao, F., \& Painho, M. (2019). Gamification: A key determinant of massive open online course (MOOC) success. Information \& Management, 56(1), 39-54. doi:10.1016/j.im.2018.06.003

Ardito, L., D'Adda, D., \& Messeni Petruzzelli, A. (2018). Mapping innovation dynamics in the internet of things domain: Evidence from patent analysis. Technological Forecasting \& Social Change, 136, 317-330. doi:10.1016/j.techfore.2017.04.022

Armstrong, \& Overton. (1977). Estimating nonrespone bias in mail surveys. Journal of Marketing Research, 14(3), 396-402. doi.org/10.1177/002224377701400320

Arpaci, I., Yardimci Cetin, Y., \& Turetken, O. (2015). A cross-cultural analysis of smartphone adoption by Canadian and Turkish organizations. Journal of Global Information Technology Management, 18(3), 214-238. doi:10.1080/1097198X.2015.1080052

Arpaci, I., Yardimci, Y. C., Ozkan, S., \& Turetken, O. (2012). Organizational adoption of information technologies: A literature review. International Journal of eBusiness and eGovernment Studies, 4(2). Retrieved from http://www.sobiad.org/eJOURNALS/journal_IJEBEG/index.html

Asghar, I., Cang, S., \& Yu, H. (2018). Usability evaluation of assistive technologies through qualitative research focusing on people with mild dementia. Computers in Human Behavior, 79, 192-201. doi:10.1016/j.chb.2017.08.034

Baker, J. (2012). The technology-organization-environment framework. In Y.K. Dwivedi, M.R. Wade \& S.L. Schneberger (Eds.), Information Systems Theory (pp. 231-245). New York, NY: Springer 
Batubara, F.R., Ubacht, J. \& Janssen, M. (2018). Challenges of blockchain technology adoption for e-government: A systematic literature review. Proceedings of the 19th Annual International Conference on Digital Government Research: Governance in the Data Age, Delft, Netherlands, May $30^{\text {th }}-$ June $1^{\text {st }}$, Association for Computing Machinery (ACM), New York, NY, USA, Article 79, pp. 1-9. doi:10.1145/3209281.3209317

Benbunan-Fich, R., \& Castellanos, A. (2018). Digitalization of land records: From paper to blockchain. Proceedings of the 39th International Conference on Information Systems (ICIS), San Francisco, CA, USA, December $13^{\text {th }}-16^{\text {th }}$, Association for Information Systems (AIS), Atlanta, GA, USA, pp 1-9. Retrieved from https://www.researchgate.net/publication/329222337_Digitalization_of_Land_Records_F rom_Paper_to_Blockchain

Bhaimia, S. (2018). The General Data Protection Regulation: The next generation of EU data protection. Legal Information Management, 18(1), 21-28.

doi:10.1017/S1472669618000051

Blind, K., Edler, J., Frietsch, R., \& Schmoch, U. (2006). Motives to patent: Empirical evidence from Germany. Research Policy, 35(5), 655-672. doi:10.1016/j.respol.2006.03.002

Braun, V., \& Clarke, V. (2006). Using thematic analysis in psychology. Qualitative Research in Psychology, 3(2), 77-101. doi:10.1191/1478088706qp063oa

Buterin, V. (2018). A next-generation smart contract and decentralized application platform. Retrieved from https:/github.com/ethereum/wiki/wiki/White-Paper\#decentralizedautonomous-organizations $\% 20$

Casino, F., Dasaklis, T. K., \& Patsakis, C. (2019). A systematic literature review of blockchainbased applications: Current status, classification and open issues. Telematics and Informatics, 36, 55-81. doi:10.1016/j.tele.2018.11.006

Ceccagnoli, M. (2009). Appropriability, preemption, and firm performance. Strategic Management Journal, 30(1), 81-98. doi:10.1002/smj.723 
Chang, I., Hwang, H., Hung, M., Lin, M., \& Yen, D. C. (2007). Factors affecting the adoption of electronic signature: Executives' perspective of hospital information department. Decision Support Systems, 44(1), 350-359. doi:10.1016/j.dss.2007.04.006

Chau, Y.K., \& Tam, K. Y. (1997). Factors affecting the adoption of open systems: An exploratory study. MIS Quarterly, 21(1), 1-24. doi:10.2307/249740

Cheah, E., \& Fry, J. (2015). Speculative bubbles in Bitcoin markets? An empirical investigation into the fundamental value of Bitcoin. Economics Letters, 130, 32-36. doi:10.1016/j.econlet.2015.02.029

Cheng, Y. (2014). Extending the expectation-confirmation model with quality and flow to explore nurses' continued blended e-learning intention. Information Technology \& People, 27(3), 230-258. doi:10.1108/ITP-01-2013-0024

Chen, Y., Wang, Y., Nevo, S., Jin, J., Wang, L., \& Chow, W. S. (2014). IT capability and organizational performance: The roles of business process agility and environmental factors. European Journal of Information Systems, 23(3), 326-342. doi:10.1057/ejis.2013.4

Christidis, K., \& Devetsikiotis, M. (2016). Blockchains and smart contracts for the internet of things. IEEE Access, 4, 2292-2303. doi:10.1109/ACCESS.2016.2566339

Cohen, J. (2013). Statistical power analysis for the behavioral sciences. Milton Park, Oxfordshire: Taylor and Francis.

Cohen, W. M., Nelson, R. R. \& Walsh, J. P. (2000). Protecting their intellectual assets: Appropriability conditions and why US manufacturing firms patent (or not). National Bureau of Economic Research, No. w7552. doi 10.3386/w7552

Cole, F. L. (1988). Content analysis: Process and application. Clinical Nurse Specialist, 2(1), 5357. doi:10.1097/00002800-198800210-00025

Cui, L., Zhang, C., Zhang, C., \& Huang, L. (2008). Exploring IT adoption process in Shanghai firms: An empirical study. Journal of Global Information Management, 16(2), 1-17. doi:10.4018/jgim.2008040101 
Daradkeh, M. K. (2019). Determinants of visual analytics adoption in organizations. Information Technology \& People, 32(3), 668-695. doi:10.1108/ITP-10-2017-0359

Davis, F. D., Bagozzi, R. P., \& Warshaw, P. R. (1989). User acceptance of computer technology: A comparison of two theoretical models. Management Science, 35(8), 982-1003. doi:10.1287/mnsc.35.8.982

Davis, F. D. (1989). Perceived usefulness, perceived ease of use, and user acceptance of information technology. MIS Quarterly, 13(3), 319-340. doi:10.2307/249008

Dehghani, M., Mashatan, A., \& Kennedy, R. W. (2020). Innovation within networks - patent strategies for blockchain technology. Journal of Business \& Industrial Marketing. doi:10.1108/JBIM-05-2019-0236

Dehghani, M., \& Dangelico, R. M. (2018). Smart wearable technologies: State of the art and evolution over time through patent analysis and clustering. International Journal of Product Development, 22(4), 293. doi:10.1504/IJPD.2018.091148

Dehghani, M., \& Dangelico, R. M. (2017). Smart wearable technologies: Current status and market orientation through a patent analysis. Proceedings of the IEEE International Conference on Industrial Technology (ICIT), Toronto, ON, Canada, March $23^{\text {rd }}-25^{\text {th }}$, Institute of Electrical and Electronics Engineers, New York, NY, USA, pp. 1570-1575. doi:10.1109/ICIT.2017.7915602

DeLone, W. H., \& McLean, E. R. (1992). Information systems success: The quest for the dependent variable. Information Systems Research, 3(1), 60-95. doi:10.1287/isre.3.1.60

Demoulin, N. T. M., \& Coussement, K. (2018). Acceptance of text-mining systems: The signaling role of information quality. Information \& Management, 57(1), 103120. doi:10.1016/j.im.2018.10.006

DeVellis, R. F. (2003). Scale development: Theory and applications. Newbury Park, CA: Sage Publications.

Dinev, T., \& Hart, P. (2006). An extended privacy calculus model for e-commerce transactions. Information Systems Research, 17(1), 61-80. doi:10.1287/isre.1060.0080 
Dobrovnik, M., Herold, D., Fürst, E., \& Kummer, S. (2018). Blockchain for and in logistics: What to adopt and where to start. Logistics, 2(3), 18-32. doi:10.3390/logistics2030018

Dong, X., Chang, Y., Wang, Y., \& Yan, J. (2017). Understanding usage of internet of things (IOT) systems in china: Cognitive experience and affect experience as moderator. Information Technology \& People, 30(1), 117-138. doi:10.1108/ITP-11-20150272

Elo, S., \& Kyngäs, H. (2008). The qualitative content analysis process. Journal of Advanced Nursing, 62(1), 107-115. doi:10.1111/j.1365-2648.2007.04569.x

European Commission. (n.d). EU data protection rules. Retrieved from https://ec.europa.eu/commission/priorities/justice-and-fundamental-rights/dataprotection/2018-reform-eu-data-protection-rules_en

Fallah, M. H., Fishman, E. \& Reilly, R. R. (2009). Forward patent citations as predictive measures for diffusion of emerging technologies. Proceedings of the International Conference on Management of Engineering \& Technology, Portland, OR, USA, August $2^{\text {nd }}-6^{\text {th }}$, Institute of Electrical and Electronics Engineers (IEEE), New York, NY, USA, pp. 420-427. doi 10.1109/PICMET.2009.5262201

Felin, T., \& Lakhani, K. (2018). What problems will you solve with blockchain? MIT Sloan Management Review, 60(1), 32-38. Retrieved from https://sloanreview.mit.edu/article/what-problems-will-you-solve-with-blockchain/

Folkinshteyn, D., \& Lennon, M. (2016). Braving bitcoin: A technology acceptance model (TAM) analysis. Journal of Information Technology Case and Application Research, 18(4), 220-249. doi:10.1080/15228053.2016.1275242

Forsman, H. (2011). Innovation capacity and innovation development in small enterprises. A comparison between the manufacturing and service sectors. Research Policy, 40(5), 739750. doi:10.1016/j.respol.2011.02.003 
Gao, Z., Xu, L., Chen, L., Zhao, X., Lu, Y., \& Shi, W. (2018). CoC: A unified distributed ledger based supply chain management system. Journal of Computer Science and Technology, 33(2), 237-248. doi:10.1007/s11390-018-1816-5

Gausdal, A., Czachorowski, K., \& Solesvik, M. (2018). Applying blockchain technology: Evidence from Norwegian companies. Sustainability, 10(6), 1985-2001. doi:10.3390/su10061985

Gordon, W. J., \& Catalini, C. (2018). Blockchain technology for healthcare: Facilitating the transition to patient-driven interoperability. Computational and Structural Biotechnology Journal, 16, 224-230. doi:10.1016/j.csbj.2018.06.003

Grand View Research. (2018). Blockchain technology market size worth $\$ 7.59$ billion by 2024. Retrieved from https://www.grandviewresearch.com/press-release/global-blockchaintechnology-market

Granetto, B., Kandaswamy, R., Lovelock J.D. \& Reynolds M. (2017). Forecast: Blockchain Business Value Worldwide, 2017-2030. Retrieved from https://www.gartner.com/en/documents/3627117

Griggs, K. N., Ossipova, O., Kohlios, C. P., Baccarini, A. N., Howson, E. A., \& Hayajneh, T. (2018). Healthcare blockchain system using smart contracts for secure automated remote patient monitoring. Journal of Medical Systems, 42(7), 1-7. doi:10.1007/s10916-0180982-X

Grover, P., Kar, A. K., Janssen, M., \& Ilavarasan, P. V. (2019). Perceived usefulness, ease of use and user acceptance of blockchain technology for digital transactions - Insights from user-generated content on Twitter. Enterprise Information Systems, 13(6), 771-800. doi:10.1080/17517575.2019.1599446

Hair, J. F., Sarstedt, M., \& Ringle, C. M. (2019). Rethinking some of the rethinking of partial least squares. European Journal of Marketing, 53(4), 566-584. doi:10.1108/EJM-102018-0665 
Hair, J. F., Hult, G. T. M., Ringle, C. M., Sarstedt, M., \& Thiele, K. O. (2017a). Mirror, mirror on the wall: a comparative evaluation of composite-based structural equation modeling methods. Journal of the Academy of Marketing Science, 45(5), 616-632. doi:10.1007/s11747-017-0517-x

Hair Jr, J. F., Sarstedt, M., Ringle, C. M., \& Gudergan, S. P. (2017b). Advanced issues in partial least squares structural equation modeling. Newbury Park, CA: Sage Publications.

Hair, J. F., Ringle, C. M., \& Sarstedt, M. (2011). PLS-SEM: Indeed a silver bullet. Journal of Marketing theory and Practice, 19(2), 139-152. doi:10.2753/MTP1069-6679190202

Hall, B. H., \& Ziedonis, R. H. (2001). The patent paradox revisited: An empirical study of patenting in the U.S. semiconductor industry, 1979-1995. The RAND Journal of Economics, 32(1), 101-128. doi:10.2307/2696400

Hanifatunnisa, R. \& Rahardjo, B. (2017). Blockchain based e-voting recording system design. Proceedings of the 11th International Conference on Telecommunication Systems Services and Applications, Lombok Indonesia, October 26th-27th, Institute of Electrical and Electronics Engineers (IEEE), New York, NY, USA, pp. 1-6. doi 10.1109/TSSA.2017.8272896

Henseler, J., Ringle, C. M., \& Sarstedt, M. (2015). A new criterion for assessing discriminant validity in variance-based structural equation modeling. Journal of the academy of marketing science, 43(1), 115-135. doi:10.1007/s11747-014-0403-8

Holotiuk, F., \& Moormann, J. (2018). Organizational adoption of digital innovation: The case of blockchain technology. Proceedings of the 26th European conference on information systems (ECIS), Portsmouth, UK, June 23rd-28th, Association for Information Systems (AIS), Atlanta, GA. Retrieved from http://ecis2018.eu/

Hong, W., \& Zhu, K. (2006). Migrating to internet-based e-commerce: Factors affecting ecommerce adoption and migration at the firm level. Information \& Management, 43(2), 204-221. doi:10.1016/j.im.2005.06.003 
Hoxha, V., \& Sadiku, S. (2019). Study of factors influencing the decision to adopt the blockchain technology in real estate transactions in Kosovo. Property Management, 37(5), 684-700. doi:10.1108/PM-01-2019-0002

Hsieh, P., \& Lin, W. (2018). Explaining resistance to system usage in the PharmaCloud: A view of the dual-factor model. Information \& Management, 55(1), 51-63. doi:10.1016/j.im.2017.03.00

Hughes, L., Dwivedi, Y. K., Misra, S. K., Rana, N. P., Raghavan, V., \& Akella, V. (2019). Blockchain research, practice and policy: Applications, benefits, limitations, emerging research themes and research agenda. International Journal of Information Management, 49, 114-129. doi:10.1016/j.ijinfomgt.2019.02.005

Hu, L.T. \& Bentler, P. M. (1999). Cutoff criteria for fit indexes in covariance structure analysis: Conventional criteria versus new alternatives. Structural Equation Modeling, 6(1), 1-55. doi:10.1080/10705519909540118

Ifinedo, P. (2011). Internet e-business technologies acceptance in canada's SMEs: An exploratory investigation. Internet Research, 21(3), 255-281. doi:10.1108/10662241111139309

Jang, S., (2010). An empirical study on the factors influencing RFID adoption and implementation. Management Review: An International Journal 5(2), 55-73. Retrieved from https://onlinelibrary.wiley.com/loi/14682370/year/2004

Janssen, M., Weerakkody, V., Ismagilova, E., Sivarajah, U., \& Irani, Z. (2020). A framework for analysing blockchain technology adoption: Integrating institutional, market and technical factors. International Journal of Information Management, 50, 302-309. doi:10.1016/j.ijinfomgt.2019.08.012

Jeong, Y., Lee, K., Yoon, B., \& Phaal, R. (2015). Development of a patent roadmap through the generative topographic mapping and bass diffusion model. Journal of Engineering and Technology Management, 38, 53-70. doi:10.1016/j.jengtecman.2015.08.006 
Jonker, N. (2019). What drives the adoption of crypto-payments by online retailers? Electronic Commerce Research and Applications, 35, 100848-100846.

doi:10.1016/j.elerap.2019.100848

Jun, S., Park, S. S., \& Jang, D. S. (2012). Patent management for technology forecasting: A case study of the bio-industry. Journal of Intellectual Property Rights, 17(6), 539-546. Retrieved from http://nopr.niscair.res.in/handle/123456789/45

Kamble, S., Gunasekaran, A., \& Arha, H. (2019). Understanding the blockchain technology adoption in supply chains-Indian context. International Journal of Production Research, 57(7), 2009-2033. doi:10.1080/00207543.2018.1518610

Kamble, S. S., Gunasekaran, A., \& Sharma, R. (2019). Modeling the blockchain enabled traceability in agriculture supply chain. International Journal of Information Management, 101967-101,983. doi:10.1016/j.ijinfomgt.2019.05.023

Kang, J., Yu, R., Huang, X., Maharjan, S., Zhang, Y., \& Hossain, E. (2017). Enabling localized peer-to-peer electricity trading among plug-in hybrid electric vehicles using consortium blockchains. IEEE Transactions on Industrial Informatics, 13(6), 3154-3164. doi:10.1109/TII.2017.2709784

Koteska, B., Karafiloski, E., \& Mishev, A. (2017). Blockchain implementation quality challenges: A literature review. Proceedings of the 6th Workshop on Software Quality Analysis, Monitoring, Improvement, and Applications (SQAMIA), Belgrade, Serbia, September 11th -14th, Centro de Estudios Urbanos (CEUR-WS), Aachen Germany, pp. 11-13. Retrieved from http://ceur-ws.org/index.html

Krippendorff, K. (2004), Content analysis: An introduction to its methodology. Newbury Park, CA: Sage Publications.

Kshetri, N. (2017). Will blockchain emerge as a tool to break the poverty chain in the global south? Third World Quarterly, 38(8), 1710-1732. doi:10.1080/01436597.2017.1298438 
Kuan, K. K. Y., \& Chau, P. Y. K. (2001). A perception-based model for EDI adoption in small businesses using a technology-organization-environment framework. Information \& Management, 38(8), 507-521. doi:10.1016/S0378-7206(01)00073-8

Lacity, M., (2018). Addressing key challenges to making enterprise blockchain applications a reality. MIS Quarterly Executive, 17(3), 201-222. Retrieved from https://aisel.aisnet.org/misqe/

Lee, C., \& Shim, J. P. (2007). An exploratory study of radio frequency identification (RFID) adoption in the healthcare industry. European Journal of Information Systems, 16(6), 712-724. doi:10.1057/palgrave.ejis.3000716

Lemley, M. A., \& Shapiro, C. (2007). Patent holdup and royalty stacking. Texas Law Review, 85(7), 1991-2049. Retrieved from https://texaslawreview.org/

Leopold, T. A., Ratcheva, V. S., \& Zahidi, S. (2018). The future of jobs report 2018. Retrieved from https://www.weforum.org/reports/the-future-of-jobs-report-2018

Leydesdorff, L. (2015). Can technology life-cycles be indicated by diversity in patent classifications? The crucial role of variety. Scientometrics, 105(3), 1441-1451. doi:10.1007/s11192-015-1639-x

Li, C. (2017). Maersk - Reinventing the Shipping Industry Using IoT and Blockchain. Retrieved from https://digital.hbs.edu/industry-4-0/maersk-reinventing-shipping-industry-using-iotblockchain/

Li, Z., Liu, X., Wang, W. M., Vatankhah Barenji, A., \& Huang, G. Q. (2019a). CKshare: Secured cloud-based knowledge-sharing blockchain for injection mold redesign. Enterprise Information Systems, 13(1), 1-33. doi:10.1080/17517575.2018.1539774

Li, J., Greenwood, D., \& Kassem, M. (2019b). Blockchain in the built environment and construction industry: A systematic review, conceptual models and practical use cases. Automation in Construction, 102, 288-307. doi:10.1016/j.autcon.2019.02.005 
Li, X., Zhou, Y., Xue, L., \& Huang, L. (2015). Integrating bibliometrics and roadmapping methods: A case of dye-sensitized solar cell technology-based industry in china. Technological Forecasting \& Social Change, 97, 205-222. doi:10.1016/j.techfore.2014.05.007

Liang, G., Weller, S. R., Luo, F., Zhao, J., \& Dong, Z. Y. (2019). Distributed blockchain-based data protection framework for modern power systems against cyber attacks. IEEE Transactions on Smart Grid, 10(3), 3162-3173. doi:10.1109/TSG.2018.2819663

Lin, S., \& Lin, H. (2008). Determinants of e-business diffusion: A test of the technology diffusion perspective. Technovation, 28(3), 135-145. doi:10.1016/j.technovation.2007.10.003

Litecoin. (2019). The Cryptocurrency for Payments. Retrieved from https://litecoin.org/

Macdonald, S. (2004). When means become ends: Considering the impact of patent strategy on innovation. Information Economics and Policy, 16(1), 135-158. doi:10.1016/j.infoecopol.2003.09.008

Makhdoom, I., Abolhasan, M., Abbas, H., \& Ni, W. (2019). Blockchain's adoption in IoT: The challenges, and a way forward. Journal of Network and Computer Applications, 125, 251-279. doi:10.1016/j.jnca.2018.10.019

Marler, J. H., Liang, X., \& Dulebohn, J. H. (2006). Training and effective employee information technology use. Journal of Management, 32(5), 721-743. doi:10.1177/0149206306292388

Martin, S. L., Javalgi, R. G., \& Ciravegna, L. (2020). Marketing capabilities and international new venture performance: The mediation role of marketing communication and the moderation effect of technological turbulence. Journal of Business Research, 107, 25-37. doi:10.1016/j.jbusres.2019.09.044

Mashatan, A., \& Roberts, Z. (2017). An enhanced real estate transaction process based on blockchain technology. Proceedings of the $23^{\text {rd }}$ Americas Conference on Information Systems: A tradition of Innovation (AMCIS), Boston, MA, USA, August $10^{\text {th }}-12^{\text {th }}$, 
America Conference on Information Systems (AMCIS), Atlanta, GA. Retrieved from https://aisel.aisnet.org/amcis/

Mazzoleni, R., \& Nelson, R. R. (1998). The benefits and costs of strong patent protection: A contribution to the current debate. Research Policy, 27(3), 273-284. doi:10.1016/S00487333(98)00048-1

Miau, S., \& Yang, J. (2018). Bibliometrics-based evaluation of the blockchain research trend: 2008 - march 2017. Technology Analysis \& Strategic Management, 30(9), 1029-1045. doi:10.1080/09537325.2018.1434138

Miles, M. B., Huberman, A. M., Huberman, M. A., \& Huberman, M. (1994). Qualitative data analysis: An expanded sourcebook. Newbury Park, CA: Sage Publications.

Mishra, A. N., Konana, P., \& Barua, A. (2007). Antecedents and consequences of internet use in procurement: An empirical investigation of U.S. manufacturing firms. Information Systems Research, 18(1), 103-120. doi:10.1287/isre.1070.0115Miau, S., \& Yang, J. (2018). Bibliometrics-based evaluation of the blockchain research trend: 2008 - march 2017. Technology Analysis \& Strategic Management, 30(9), 1029-1045. doi:10.1080/09537325.2018.1434138

Moezkarimi, Z., Nourmohammadi, R., Zamani, S., Abdollahei, F., Golmirzaei, Z., \& Arabsorkhi, A. (2019). An overview on technical characteristics of blockchain platforms. Proceedings of the 2nd International Congress on High-Performance Computing and Big Data Analytics, Tehran, Iran, April 23rd -25th, Springer, New York, NY, USA. doi: 10.1007/978-3-030-33495-6_20

Moore, G. C., \& Benbasat, I. (1991). Development of an instrument to measure the perceptions of adopting an information technology innovation. Information Systems Research, 2(3), 192-222. doi:10.1287/isre.2.3.192

Motohashi, K., \& Tomozawa, T. (2016). Differences in science based innovation by technology life cycles: The case of solar cell technology. International Journal of Technology Management, 72(1/2/3), 5-23. doi:10.1504/IJTM.2016.080539 
Naicker, V., \& Van Der Merwe, D.B., (2018). Managers' perception of mobile technology adoption in the life insurance industry. Information Technology \& People, 31(2), 507526. doi:10.1108/ITP-09-2016-0212

Nakamoto, S. (2008). Bitcoin: A peer-to-peer electronic cash system. Retrieved from https://nakamotoinstitute.org/bitcoin/

Narayanan, A., Bonneau, J., Felten, E., Miller, A., \& Goldfeder, S. (2016). Bitcoin and cryptocurrency technologies: A comprehensive introduction. Princeton, NJ: Princeton University Press.

Naudet, Y., Latour, T., Guedria, W., \& Chen, D. (2010). Towards a systemic formalisation of interoperability. Computers in Industry, 61(2), 176-185. doi:10.1016/j.compind.2009.10.014

Norton, P. T., Rodriguez, H. P., Shortell, S. M., \& Lewis, V. A. (2019). Organizational influences on healthcare system adoption and use of advanced health information technology capabilities. The American Journal of Managed Care, 25(1), e21-. Retrieved from https://www.ajmc.com/journals/issue/2019/2019-vol25-n1

Pan, M., \& Jang, W. (2008). Determinants of the adoption of enterprise resource planning within the technology-organization-environment framework: Taiwan's communications industry. Journal of Computer Information Systems, 48(3), 94-102. doi:10.1080/08874417.2008.11646025

Park, E., Kim, K. J., \& Kwon, S. J. (2016). Understanding the emergence of wearable devices as next-generation tools for health communication. Information Technology \& People, 29(4), 717-732. doi:10.1108/ITP-04-2015-0096

Podsakoff, P. M., MacKenzie, S. B., Lee, J. Y., \& Podsakoff, N. P. (2003). Common method biases in behavioral research: A critical review of the literature and recommended remedies. Journal of applied psychology, 88(5), 879. doi:10.1037/0021-9010.88.5.879

PwC. (2018). Blockchain is here. What is your next move? Retrieved from https://www.pwc.com/gx/en/issues/blockchain/blockchain-in-business.html 
Queiroz, M. M., \& Fosso Wamba, S. (2019). Blockchain adoption challenges in supply chain: An empirical investigation of the main drivers in India and the USA. International Journal of Information Management, 46, 70-82. doi:10.1016/j.ijinfomgt.2018.11.021

Ranganathan, C., Teo, T. S. H., \& Dhaliwal, J. (2011). Web-enabled supply chain management: Key antecedents and performance impacts. International Journal of Information Management, 31(6), 533-545. doi:10.1016/j.ijinfomgt.2011.02.004

Rauschnabel, P. A. (2018). Antecedents to the adoption of augmented reality smart glasses: A closer look at privacy risks. Journal of Business Research, 92, 374-384. doi:10.1016/j.jbusres.2018.08.008

Raut, R. D., Priyadarshinee, P., Gardas, B. B., \& Jha, M. K. (2018). Analyzing the factors influencing cloud computing adoption using three stage hybrid SEM-ANN-ISM (SEANIS) approach. Technological Forecasting \& Social Change, 134, 98-123. doi:10.1016/j.techfore.2018.05.020

Raymond, L., Bergeron, F., \& Blili, S. (2005). The assimilation of E-business in manufacturing SMEs: Determinants and effects on growth and internationalization. Electronic Markets, 15(2), 106-118. doi:10.1080/10196780500083761

Reitzig, M., Henkel, J., \& Heath, C. (2007). On sharks, trolls, and their patent prey: Unrealistic damage awards and firms' strategies of “being infringed”. Research Policy, 36(1), 134154. doi:10.1016/j.respol.2006.10.003

Reitzig, M. (2004). Improving patent valuations for management purposes: Validating new indicators by analyzing application rationales. Research Policy, 33(6), 939-957. doi:10.1016/j.respol.2004.02.004

Rhee, J., Park, T., \& Lee, D. H. (2010). Drivers of innovativeness and performance for innovative SMEs in South Korea: Mediation of learning orientation. Technovation, 30(1), 65-75. doi:10.1016/j.technovation.2009.04.008

Ripple. (2019). RippleNet. One Frictionless Experience to Send Money Globally. Retrieved from https://www.ripple.com/ripplenet/ 
Rivette, K. G., \& Kline, D. (2000). Discovering new value in intellectual property. Harvard Business Review, 78(1), 54-66. Retrieved from https://hbr.org/

Rogers, E. M. (2003). Diffusion of innovations. New York, NY: The Free Press.

Rogers, E. M. (1995). Diffusion of innovations. New York, NY: The Free Press.

Rogers, E. M. (1962). Diffusion of innovations. New York, NY: The Free Press.

Rossow, A. (2018). Why Walmart's move to the blockchain could do more than prevent E. coli outbreaks. Retrieved from https://www.forbes.com/sites/andrewrossow/2018/09/25/whywalmarts-move-to-the-blockchain-could-do-more-than-cure-e-colioutbreaks/\#7819b00f1100

Ryu, H. (2018). What makes users willing or hesitant to use fintech?: The moderating effect of user type. Industrial Management \& Data Systems, 118(3), 541-569. doi:10.1108/IMDS07-2017-0325

Sander, F., Semeijn, J., \& Mahr, D. (2018). The acceptance of blockchain technology in meat traceability and transparency. British Food Journal, 120(9), 2066-2079. doi:10.1108/BFJ-07-2017-0365 doi: 10.1007/978-3-319-45153-4_48

Sharples, M. \& Domingue, J. (2016).The blockchain and kudos: A distributed system for educational record, reputation and reward. Proceedings of the 11th European Conference on Technology Enhanced Learning (EC-TEL), Lyon, France, September 13th - 16th, Springer, Berlin, Germany, pp. 490-496. doi: 10.1007/978-3-319-45153-4_48

Shen, C., \& Pena-Mora, F. (2018). Blockchain for cities-A systematic literature review. IEEE Access, 6, 76787-76819. doi:10.1109/ACCESS.2018.2880744

Somaya, D. (2012). Patent strategy and management: An integrative review and research agenda. Journal of Management, 38(4), 1084-1114. doi:10.1177/0149206312444447

Sovbetov, Y. (2018). Factors influencing cryptocurrency prices: Evidence from Bitcoin, Ethereum, Dash, Litcoin, and Monero. Journal of Economics and Financial Analysis, 2(2), 1-27. doi:10.1991/jefa.v2i2.a16 
Stake, R. E. (1995). The art of case study research. Newbury Park, CA: Sage Publications.

Statista. (2018). Blockchain adoption phases in organizations worldwide as of April 2018, by industry. Retrieved from https://www.statista.com/statistics/878748/worldwideproduction-phase-blockchain-technology-industry/

Statista. (2016). Size of the blockchain technology market worldwide from 2016-2021 (in U.S. dollars). Retrieved from https://www.statista.com/statistics/647231/worldwideblockchain-technology-market-size/

Suh, K., Kim, H., \& Suh, E. K. (2011). What if your avatar looks like you? Dual-congruity perspectives for avatar use. MIS Quarterly, 35(3), 711-729. doi:10.2307/23042805

Supranee, S., \& Rotchanakitumnuai, S. (2017). The acceptance of the application of blockchain technology in the supply chain process of the Thai automotive industry. Proceedings of the 17th International Conference on Electronic Business: Smart Cities (ICEB), Dubai, United Arab Emirates, December $4^{\text {th }}-8^{\text {th }}$, Institute of Electrical and Electronics Engineers, New York, NY, USA, pp. 252-257. Retrieved from http://iceb2017.johogo.com/

Swan, M. (2015). Blockchain: Blueprint for a new economy. Sebastpol, CA: O'Reilly Media.

Taufiq, R., Meyliana, Hidayanto, A.N. \& Prabowo, H. (2018). The affecting factors of blockchain technology adoption of payments systems in Indonesia banking industry. Proceedings of 2018 International Conference on Information Management and Technology (ICMTech), Jakarta, Indonesia, September 3-5 ${ }^{\text {th }}$, Institute of Electrical and Electronics Engineers, New York, NY, USA, pp. 506-510. doi:

10.1109/ICIMTech.2018.8528104

Tenenhaus, M., \& Hanafi, M. (2010). A bridge between PLS path modeling and multi-block data analysis. In V. E. Vinzi, W.W. Chin, J. Henseler, \& H. Wang (Eds.), Handbook of partial least squares (pp. 99-123). Heidelberg, Berlin: Springer.

Thiruchelvam, V., Mughisha, A. S., Shahpasand, M., \& Bamiah, M. (2018). Blockchain-based technology in the coffee supply chain trade: Case of Burundi coffee. Journal of 
Telecommunication, Electronic and Computer Engineering, 10(3-2), 121-125. Retrieved from http://journal.utem.edu.my/index.php/jtec/index

Thong, J. Y. L. (1999). An integrated model of information systems adoption in small businesses. Journal of Management Information Systems, 15(4), 187-214. doi:10.1080/07421222.1999.11518227

Tomás, S., Thomas, M., \& Oliveira, T. (2018). Evaluating the impact of virtualization characteristics on SaaS adoption. Enterprise Information Systems, 12(3), 259-278. doi:10.1080/17517575.2017.1355484

Tomasin, L., Pereira, G. M., Borchardt, M., \& Sellitto, M. A. (2013). How can the sales of green products in the Brazilian supply chain be increased? Journal of Cleaner Production, 47, 274-282. doi:10.1016/j.jclepro.2013.01.028

Tung, F., Chang, S., \& Chou, C. (2008). An extension of trust and TAM model with IDT in the adoption of the electronic logistics information system in HIS in the medical industry. International Journal of Medical Informatics, 77(5), 324-335. doi:10.1016/j.ijmedinf.2007.06.006

Tornatzky, L., \& Fleischer, M. (1990). The process of technology innovation. Lexington, MA: Lexington Books.

Tseng, Y., Lin, Y., \& Lin, C. (2007). Text mining techniques for patent analysis. Information Processing and Management, 43(5), 1216-1247. doi:10.1016/j.ipm.2006.11.011

Van Hoek, R. (2019). Exploring blockchain implementation in the supply chain: Learning from pioneers and RFID research. International Journal of Operations \& Production Management, 39(6/7/8), 829-859. doi:10.1108/IJOPM-01-2019-0022

Veer, T., \& Jell, F. (2012). Contributing to markets for technology? A comparison of patent filing motives of individual inventors, small companies and universities. Technovation, 32(9-10), 513-522. doi:10.1016/j.technovation.2012.03.002 
Venkatesh, V., Brown, S., \& A., Bala, H. (2013). Bridging the qualitative-quantitative divide: Guidelines for conducting mixed methods research in information systems. MIS Quarterly, 37(1), 21-54. doi:10.25300/MISQ/2013/37.1.02

Venkatesh, V., James Y. L. Thong, \& Xu, X. (2012). Consumer acceptance and use of information technology: Extending the unified theory of acceptance and use of technology. MIS Quarterly, 36(1), 157-178. doi:10.2307/41410412

Venkatesh, V., \& Bala, H. (2008). Technology acceptance model 3 and a research agenda on interventions. Decision Sciences, 39(2), 273-315. doi:10.1111/j.1540-5915.2008.00192.x

Venkatesh, V., Morris, M. G., Davis, G. B., \& Davis, F. D. (2003). User acceptance of information technology: Toward a unified view. MIS Quarterly, 27(3), 425-478. doi: $10.2307 / 30036540$

Venkatesh, V., \& Davis, F. D. (2000). A theoretical extension of the technology acceptance model: Four longitudinal field studies. Management Science, 46(2), 186-204. doi:10.1287/mnsc.46.2.186.11926

Voss, C. (2010). Case research in operations management. In C. Karlsson (Ed.), Researching operations management (176-209). Abingdon, UK: Routledge.

Waltman, L., Van Eck, N. J., \& Noyons, E. C. M. (2010). A unified approach to mapping and clustering of bibliometric networks. Journal of Informetrics, 4(4), 629-635. doi:10.1016/j.joi.2010.07.002

Wang, Y., Wang, J., Singgih, M., \& Rit, M. (2019a). Making sense of blockchain technology: How will it transform supply chains? International Journal of Production Economics, 211, 221-236. doi:10.1016/j.ijpe.2019.02.002

Wang, Y., Han, J. H., \& Beynon-Davies, P. (2019b). Understanding blockchain technology for future supply chains: A systematic literature review and research agenda. Supply Chain Management: An International Journal, 24(1), 62-84. doi:10.1108/SCM-03-2018-0148

Wang, H., Zhao, Y., Dang, B., Han, P., \& Shi, X. (2019). Network centrality and innovation performance: The role of formal and informal institutions in emerging 
economies. Journal of Business \& Industrial Marketing, 34(6), 1388-1400.

doi:10.1108/JBIM-09-2017-0228

Wang, Y., \& Kogan, A. (2018). Designing confidentiality-preserving blockchain-based transaction processing systems. International Journal of Accounting Information Systems, 30, 1-18. doi:10.1016/j.accinf.2018.06.001

Wang, H., Chen, K., \& Xu, D. (2016). A maturity model for blockchain adoption. Financial Innovation, 2(1), 1-5. doi:10.1186/s40854-016-0031-z

Wanitcharakkhakul, L., \& Rotchanakitumnuai, S. (2017). Blockchain Technology Acceptance in Electronic Medical Record System. Proceedings of the International Conference on Electronic Business (ICEB), Dubai, United Arab Emirates, December 4th -8th, International Consortium for Electronic Business, pp.53-58. Retrieved from http://www.icebnet.org/

Weinstock, C., \& Goodenough, J. (2006). On system scalability, performance-critical systems. School of Computer Science Carnegie. Retrieved from https://resources.sei.cmu.edu/asset_files/TechnicalNote/2006_004_001_14681.pdf

Wong, L., Leong, L., Hew, J., Tan, G. W., \& Ooi, K. (2019). Time to seize the digital evolution: Adoption of blockchain in operations and supply chain management among Malaysian SMEs. International Journal of Information Management, 101997-102016. doi:10.1016/j.ijinfomgt.2019.08.005

Xu, S., Zhu, K., \& Gibbs, J. (2004). Global technology, local adoption: A cross-country investigation of internet adoption by companies in the United States and China. Electronic Markets, 14(1), 13-24. doi:10.1080/1019678042000175261

Yaga, D., Mell, P., Roby, N., \& Scarfone, K. (2018). Blockchain technology overview. Draft NISTIR, 8202. Retrieved from https://doi.org/10.6028/NIST.IR.8202

Yang, C. (2019). Maritime shipping digitalization: Blockchain-based technology applications, future improvements, and intention to use. Transportation Research, 131, 108-117. doi:10.1016/j.tre.2019.09.020 
Yin, R. K. (2017). Case study research and applications: Design and methods. Newbury Park, CA: Sage Publications.

Yin, F., Liu, M., \& Lin, C. (2015). Forecasting the continuance intention of social networking sites: Assessing privacy risk and usefulness of technology. Technological Forecasting \& Social Change, 99, 267-272. doi:10.1016/j.techfore.2015.07.019

Yin, R. K. (2014). Case Study Research: Design and Methods. Newbury Park, CA: Sage Publications.

Yin, R. K. (2011). Applications of case study research. Newbury Park, CA: Sage Publications.

Yin, R. K. (1994). Case study research: design and methods. Newbury Park, CA: Sage Publications.

Yli-Huumo, J., Ko, D., Choi, S., Park, S., \& Smolander, K. (2016). Where is current research on blockchain technology? A systematic review. PloS One, 11(10), e0163477. doi:10.1371/journal.pone.0163477

Zamani, E., He, Y., \& Phillips, M. (2018). On the security risks of the blockchain. Journal of Computer Information Systems, 1-12. doi:10.1080/08874417.2018.1538709

Ziedonis, R. H. (2004). Don't fence me in: Fragmented markets for technology and the patent acquisition strategies of firms. Management Science, 50(6), 804-820. doi:10.1287/mnsc. 1040.0208

Zhu, K., Kraemer, K. L., \& Xu, S. (2006). The process of innovation assimilation by firms in different countries: A technology diffusion perspective on E-business. Management Science, 52(10), 1557-1576. doi:10.1287/mnsc.1050.0487

Zhu, K., \& Kraemer, K. L. (2005). Post-adoption variations in usage and value of e-business by organizations: Cross-country evidence from the retail industry. Information Systems Research, 16(1), 61-84. doi:10.1287/isre.1050.0045 